UNIVERSIDADE DE SÃO PAULO

FFCLRP -Departamento de Física e Matemática

Programa de Pós-Graduação em FÍSICA APLICADA À MEDICINA E BIOLOGIA

\title{
Estudo computacional sobre a influência de sinapses elétricas entre bastonetes na faixa dinâmica escotópica da retina de vertebrados
}

\author{
Rodrigo Publio
}

Tese de Doutorado apresentada à Faculdade de Filosofia Ciências e Letras de Ribeirão Preto, como parte das exigências para a obtenção do título de DOUTOR EM CIÊNCIAS.

Área: FÍSICA APLICADA À MEDICINA E BIOLOGIA.

Ribeirão Preto - SP

2008 
UNIVERSIDADE DE SÃO PAULO

FFCLRP -Departamento de Física e Matemática

Programa de Pós-Graduação em FÍSICA APLICADA À MEDICINA E BIOLOGIA

\section{Estudo computacional sobre a influência de sinapses elétricas entre bastonetes na faixa dinâmica escotópica da retina de vertebrados}

Tese de Doutorado apresentada à Faculdade de Filosofia Ciências e Letras de Ribeirão Preto, como parte das exigências para a obtenção do título de DOUTOR EM CIÊNCIAS.

Área: FÍSICA APLICADA À MEDICINA E BIOLOGIA.

Aluno: Rodrigo Publio

Orientador: Prof. Dr. Antônio Carlos Roque da Silva Filho

Ribeirão Preto - SP

2008 


\section{Índice}

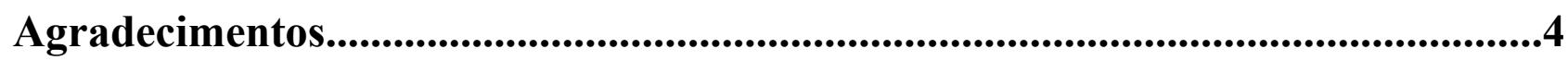

Lista de Figuras......................................................................................................................5

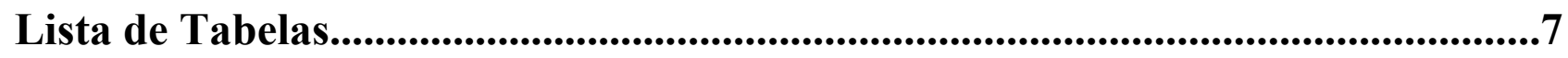

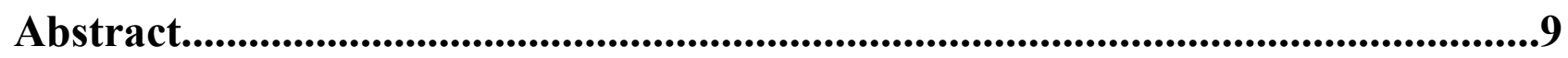

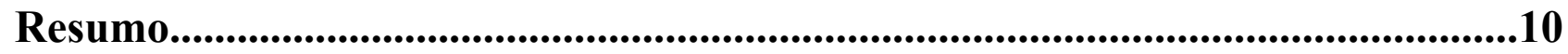

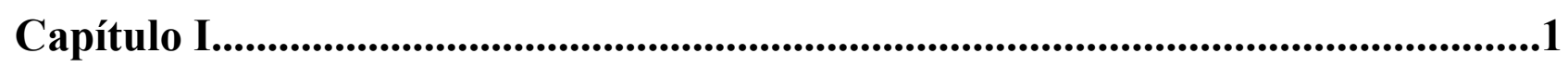

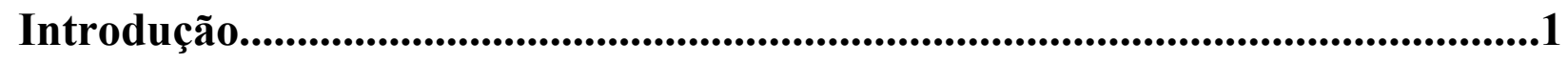

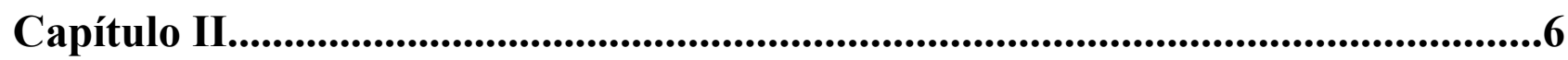

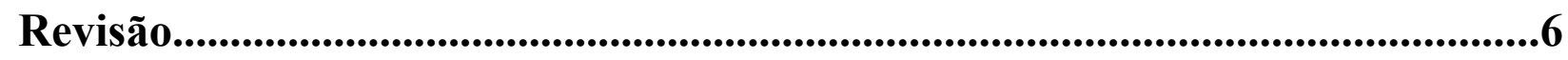

Equação de membrana e formalismo de Hodgkin-Huxley...............................................6

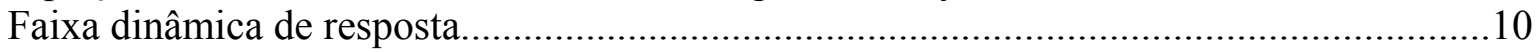

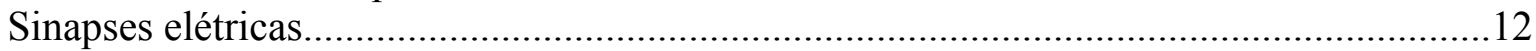

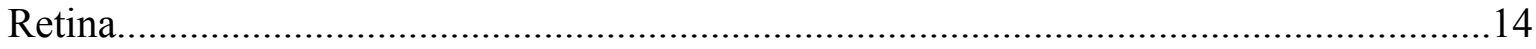

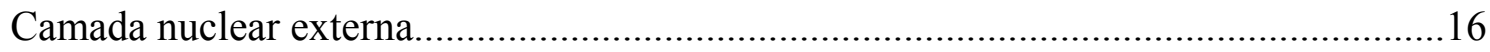

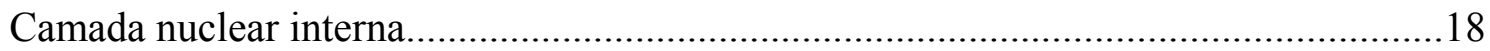

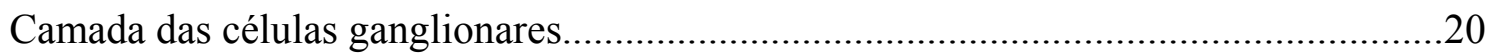

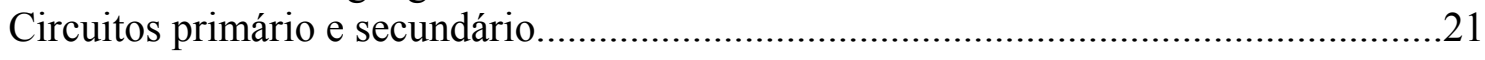

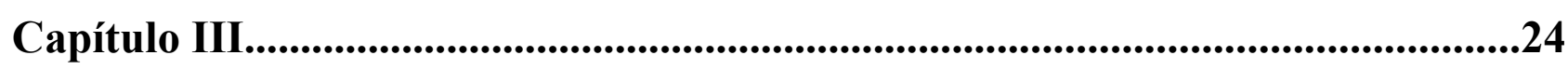

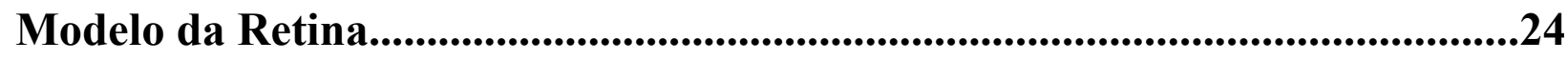

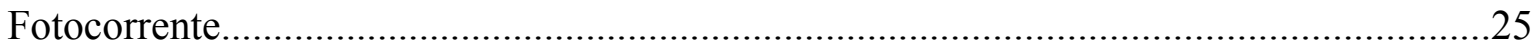

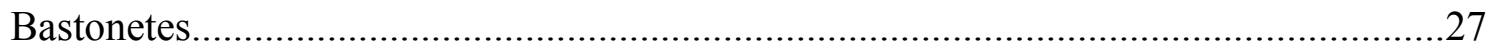

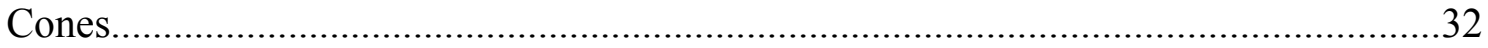

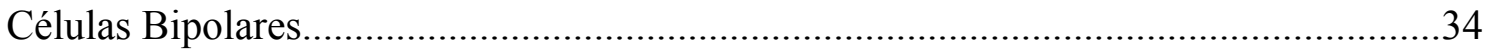

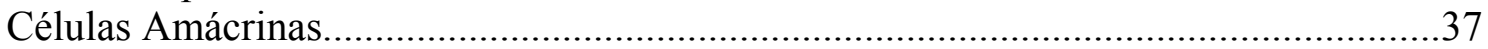

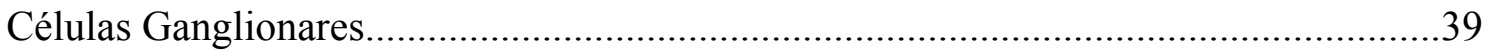

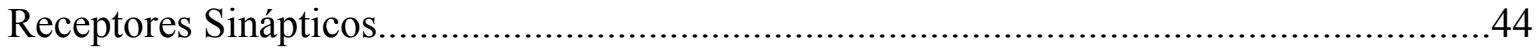

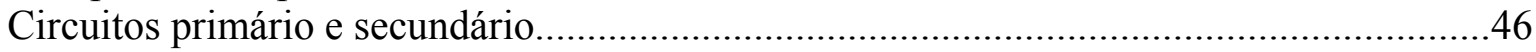

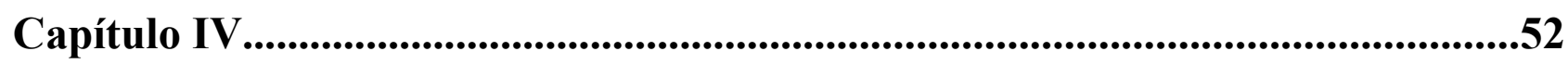

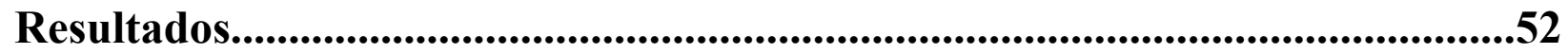

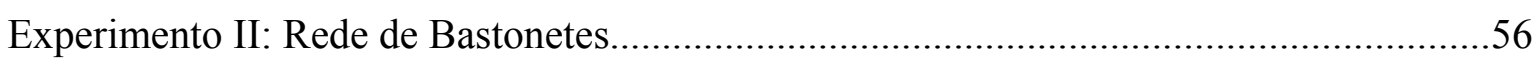

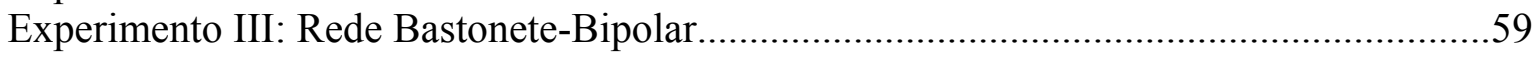

Capítulo VI....................................................................................................................................71 
Discussão dos resultados e aproximações do modelo . .71

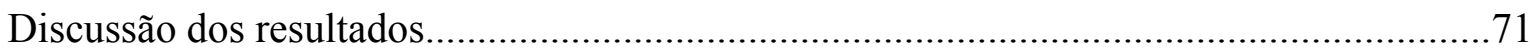

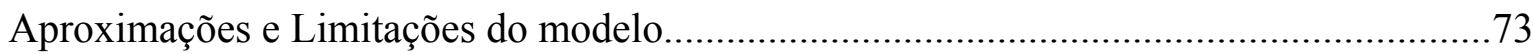

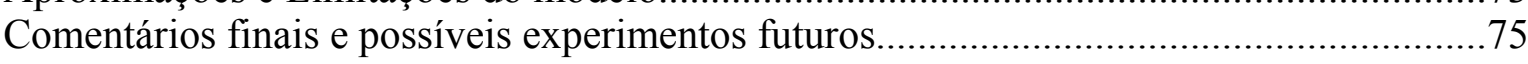

Capítulo VI...................................................................................................................................78

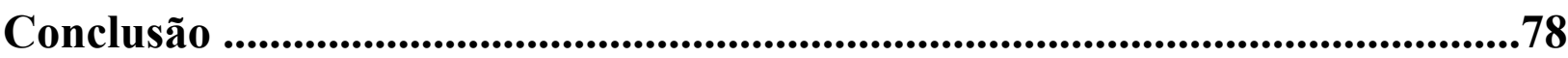

Referências Bibliográficas............................................................................................81 
Publio, Rodrigo

Estudo computacional sobre a influência de sinapses elétricas entre bastonetes na faixa dinâmica escotópica da retina de vertebrados. Ribeirão Preto, 2008.

100 p. :25 il. ; $31 \mathrm{~cm}$.

Tese de doutorado apresentada à Faculdade de Filosofia Ciências e Letras de Ribeirão

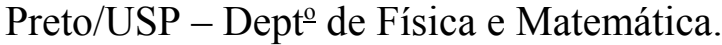

Orientador: Antônio Carlos Roque da Silva Filho.

1. Faixa dinâmica. 2. Sinapses elétricas 3. Simulação computacional. 4. Modelagem compartimental. 5. Retina. 6. Visão escotópica 


\section{Agradecimentos}

Agradeço a minha família pelo apoio e compreensão nos momentos de isolamento durante o período do doutorado. À minha mãe pelo apoio, carinho e incentivo em todas as novas "aventuras" desde que se tornou uma mãe-pai, e agora continuará me apoiando através da web-cam, skype e derivados. À minha avó, Daisy, Débora, Ciro e meu irmão pelos conselhos e pelos momentos de descontração aos fins de semana.

À minha esposa, Aloana, que teve que me agüentar todos os dias que estava de mal humor com as simulações, além de agüentar as constantes viagens para cursos e congressos e meu hobby pouco ortodoxo aos sábados. À Aloana, principalmente pela coragem e abdicação ao encarar uma nova vida no Japão, deixando família e empregos para trás. Aos meus sogros e cunhados por me agüentarem 30 horas por dia em sua casa durante os longos 7 anos (ou 8?) de namoro.

Aos meus amigos Herique "Pedra", Matheus "Tetão" e Thiago "Narigão" pelas discussões filosóficas regadas a cerveja, pelas discussões profissionais e por construir o show temático mais famoso de Ribeirão, o "Show do Tetão". Aos vários amigos de trabalho, futebol e magic pela companhia e diversão.

Aos amigos do laboratório, Rodrigo "II" Oliveira, Lucas Baggio, Diogo Porfirio, Julian Tejada, Carlos Estombelo, Janaína de Carvalho, Denise Arruda e Tiago Corrêa por participarem com idéias e sugestões, além de sempre participarem na organização dos eventos que ajudam a construir um laboratório cada vez melhor.

Ao meu orientador pelo paciência e cuidado nas correções dos artigos, relatórios e tese. Por sempre ter participado ativamente em todas as etapas de elaboração do trabalho e por sempre me incentivar a melhorar, participando de cursos, congressos e agora na ida ao Japão. Meu futuro profissional será dos melhores se sempre for acompanhado por pessoas assim.

À Fundação de Amparo à pesquisa do estado de São Paulo - FAPESP pelo suporte financeiro que permitiu a realização deste trabalho. 


\section{Lista de Figuras}

Figura 1. Estrutura dos canais iônicos dependentes do potencial de membrana. Em (A) e (B) o canal não está ativado, até que sensores do potencial permitem a abertura do portão de ativação, permitindo a passagem de íons em (C). Em seguida o portão de inativação bloqueia o canal em (D). Figura adaptada de IZHIKEVICH, 2006.

Figura 2. Curva FxI em unidades arbitrárias de estímulo e freqüência. A faixa dinâmica é indicada por $\Delta$ e a intensidade do estímulo para a qual a freqüência começa a aumentar a partir do valor mínimo é indicada por $\varepsilon$. As freqüências fmin e fmax indicam, respectivamente, o limiar de resposta e o ponto de saturação. Figura adaptada de NIZAMI, 2002.

Figura 3. Terminais sinápticos de duas células conectadas por junções gap. As conexinas são representadas conectando os citoplasmas das duas células. No caso de uma sinapse bi-direcional, os íons e pequenas moléculas podem passar em ambos sentidos. Figura adaptada de BEAR et al., 2002.

Figura 4. Organização laminar da retina. A luz que incide na retina atravessa todas as camadas até atingir o epitélio pigmentar, onde estão contidos os segmentos externos dos fotorreceptores. A única saída da retina é através da células ganglionares. Figura adaptada de BEAR et al., 2002.

Figura 5. Circuitos primário e secundário mediados pelos bastonetes na retina de mamíferos. As sinapses elétricas estão representadas por estrelas. A. no circuito primário os bastonetes enviam sinais para as células bipolares dos bastonetes (RB) e em seguida para as células amácrinas do tipo AII (AII). As células amácrinas realizam sinapses elétricas entre si e com as células bipolares dos cones (CB), que transmitem os sinais para as células ganglionares (GC) através de uma sinapse química excitatória. B. no circuito secundário os sinais recebidos pelos bastonetes são transmitidos para os cones através das sinapses elétricas existentes entre os bastonete e os cones. Em seguida, os cones enviam os sinais para as células bipolares dos cones que realizam contatos sinápticos diretos com as células ganglionares. Figura adaptada de VOLGYI et al., 2004.

Figura 6. Relação entre o estímulo luminoso e a corrente que flui entre os compartimentos do bastonete. Na ausência de estímulo existe a corrente de escuro representada por Escuro na figura, cujo valor é de $40 \mathrm{pA}$. Na presença do estímulo luminoso, a corrente é parcialmente bloqueada, dando origem a uma corrente de nova amplitude (representada na figura por A). A figura mostra a resposta da fotocorrente a uma série de estímulos de intensidades crescentes.

Figura 7. Respostas simuladas à fotocorrente. O gráfico mostra o potencial de membrana do bastonete em resposta ao estímulo para uma série de fotocorrentes (dadas na figura 6) de amplitude variando de $10 \mathrm{pA}$ a $50 \mathrm{pA}$ em passos de 10 pA e duração $6 \mathrm{~s}$. A inserção à direita do gráfico representa a resposta experimental obtida para uma série de estímulos de amplitude crescente de 38 fótons $/ \mu \mathrm{m} 2$ a 2301 fótons $/ \mu \mathrm{m} 2$. Resposta experimental retirada de SCHNEEWEIS \& SCHNAPF, 1999.

Figura 8. Respostas do modelo de célula bipolar a uma corrente injetada no compartimento. O gráfico mostra o potencial de membrana em resposta ao estímulo de amplitude de 20 pA e duração $2 \mathrm{~s}$. A inserção abaixo do gráfico representa a resposta experimental obtida para um mesmo estímulo. Resposta experimental adaptada de KANEKO \& TACHIBANA, 1985.

Figura 9. Potenciais de ação gerados pelo modelo compartimental da célula ganglionar para um estímulo de amplitude 10 pA e duração de 1000 ms. A inserção abaixo do gráfico representa a resposta obtida experimentalmente para a célula ganglionar a um estímulo de mesma amplitude. Resposta experimental retirada de FOHLMEISTER \& MILLER, 1997.

Figura 10. Diagrama de fase do modelo de célula ganglioar para os cinco valores indicados de amplitude do estímulo. As diferentes etapas de um potencial de ação estão indicadas no diagrama, onde cada cor representa a resposta obtida para uma determinada amplitude de estímulo.

Figura 11. Estrutura do modelo de retina. Cada bastonete se conecta com os seus primeiros vizinhos de acordo com o valor do índice de conectividade $\kappa$. Ainda de acordo com este mesmo índice, cada cone se conecta, em média, com $\kappa$ bastonetes aleatórios da rede de bastonetes e cada célula amácrina AII se conecta, em média, com seus $\kappa$ primeiros vizinhos. Os valores de divergência entre as camadas são utilizado para determinar o número de sinapses químicas, e estão representados na tabela 17 . 
Figura 12. Respostas simuladas à fotocorrente. O gráfico da esquerda mostra o potencial de membrana do bastonete em resposta ao estímulo na presença da corrente $\mathrm{Ih}$, enquanto o gráfico da direita mostra o potencial de membrana do bastonete em resposta ao estímulo com a corrente Ih completamente bloqueada. Para ambos os casos uma série de fotocorrentes (figura 6) de amplitude variando de $10 \mathrm{pA}$ a $50 \mathrm{pA}$ em passos de $10 \mathrm{pA}$ e duração $6 \mathrm{~s}$ foi aplicada.

Figura 13. Gráfico em escala linear-log do pico de resposta do potencial de membrana do modelo de bastonete para diferentes níveis de bloqueio do canal ativado pela hiperpolarização Ih em função da amplitude da fotocorrente aplicada ao bastonete.

Figura 14. Faixa de resposta dinâmica do bastonete isolado em função da condutância do canal ativado pela hiperpolarização Ih da membrana.

Figura 15. Faixa dinâmica da rede de bastonetes em função do índice de conectividade da rede. Para todos os casos uma condutância de $0.5 \mathrm{nS}$ para o canal Ih foi adotada.

Para verificar o efeito combinado do índice de conectividade $\kappa$ e da condutância gih do canal Ih sobre a faixa dinâmica da rede de bastonetes, o experimento descrito acima foi repetido para todas as combinações possíveis entre $\kappa$ e valores de gih dentro de uma faixa de valores que está de acordo com os dados disponíveis na literatura (KAMIYAMA et al., 1996 ; MAO et al., 2003; LIU \& KOURENNYI., 2004). O resultado está dado no diagrama da figura 16. 57

Figura 17. Potencial de membrana em função da amplitude da fotocorrente de entrada (mesmas fotocorrentes da figura 6, com amplitudes variando de $10 \mathrm{pA}$ a $50 \mathrm{pA}$ em passos de $10 \mathrm{pA}$ ) para um bastonete (esquerda) e uma célula bipolar do bastonete (direita). O bastonete faz uma sinapse química sobre a célula bipolar.

Figura 18. Faixa dinâmica da rede de células bipolares dos cones em função do índice de conectividade da rede de bastonetes e da condutância do canal Ih dos bastonetes.

Figura 19. Faixa dinâmica da rede de células bipolares em função do índice de conectividade da rede de bastonetes. Cada figura indica a faixa dinâmica medida nas células bipolares quando a condutância do canal Ih dos bastonetes assume o valor indicado em cada gráfico.

Figura 20. Faixa dinâmica da rede de células bipolares que recebe sinapses químicas com ganho reduzido dos bastonetes, em função do índice de conectividade da rede de bastonetes e da condutância do canal Ih dos bastonetes. Para todas as combinações de parâmetros do diagrama, foi utilizado Vslope $=20 \mathrm{mV}$ na equação 18.

Figura 21. Faixa dinâmica da célula ganglionar do modelo de retina em função do índice de conectividade da camada receptora e da condutância do canal Ih dos bastonetes. Neste caso, o índice de conectividade da camada de células amácrinas AII foi fixado em $\kappa=2$.

Figura 22. Freqüência de disparos da célula ganglionar em função da amplitude do estímulo na camada receptora em escala linear-log. Curva teórica obtida para o modelo completo de retina com gih $=2.5 \mathrm{nS}$ e $\kappa=1$.

Figura 23. Diagrama de fase da célula ganglionar para os cinco valores de amplitude do estímulo indicados na figura. Cada cor representa a resposta medida na célula ganglionar para uma determinada amplitude de estímulo. Todas as curvas foram obtidas considerando o modelo completo de retina com gih $=2 \mathrm{nS}$ e $\kappa=1$.

Figura 24. Faixa dinâmica do modelo de célula ganglionar da retina em função do índice de conectividade da camada de células amácrinas AII e da condutância do canal Ih dos bastonetes. Neste caso, o índice de conectividade na camada de células receptoras foi fixado em $\kappa=2$.

Figura 25. Variação percentual da faixa dinâmica em relação ao seu máximo valor em função do índice de conectividade, para diferentes camadas do modelo. A figura à esquerda representa os resultados obtidos através da média calculada para cada uma das linhas do diagrama da figura 21. A figura à direita representa os resultados obtidos para cada uma das linhas do diagrama da figura 24. 


\section{Lista de Tabelas}

Tabela 1. Parâmetros passivos utilizados na construção do modelo do bastonete. A última coluna da tabela contém as referências de onde foram retirados os valores.

Tabela 2. Equações para as taxas de variação e correntes iônicas utilizadas no modelo. A última coluna da tabela contém as referências de onde as equações foram retiradas ou adaptadas.

Tabela 3. Parâmetros utilizados no modelo do bastonete para as taxas de variação, condutâncias máximas e correntes iônicas. A última coluna da tabela contém as referências de onde os parâmetros foram retirados ou adaptados.

Tabela 4. Equações para as taxas de variação e correntes iônicas utilizadas no modelo de cone. A última coluna da tabela contém as referências de onde as equações foram retiradas ou adaptadas.

Tabela 5. Parâmetros utilizados no modelo de cone para as taxas de variação e correntes iônicas. A última coluna da tabela contém as referências de onde os parâmetros foram retirados ou adaptados.

Tabela 6. Parâmetros passivos utilizados na construção do modelo da célula bipolar. A última coluna da tabela contém as referências de onde foram retirados os valores.

Tabela 7. Equações para as taxas de variação e correntes iônicas utilizadas no modelo de célula bipolar. A última coluna da tabela contém as referências de onde as equações foram retiradas ou adaptadas. 36

Tabela 8. Parâmetros utilizados no modelo da célula bipolar para as taxas de variação, condutâncias máximas e correntes iônicas. A última coluna da tabela contém as referências de onde os parâmetros foram retirados ou adaptados.

Tabela 9. Parâmetros passivos utilizados na construção do modelo da célula amácrina AII. A última coluna da tabela contém as referências de onde foram retirados os valores.

Tabela 10. Equações para as taxas de variação e correntes iônicas utilizadas no modelo da célula amácrina AII. A última coluna da tabela contém as referências de onde as equações foram retiradas ou adaptadas.

Tabela 11. Parâmetros utilizados modelo da célula amácrina AII para as taxas de variação, condutâncias máximas e correntes iônicas. A última coluna da tabela contém as referências de onde os parâmetros foram retirados ou adaptados.

Tabela 12. Parâmetros passivos utilizados na construção do modelo da célula ganglionar. A última coluna da tabela contém as referências de onde foram retirados os valores.

Tabela 13. Equações para as taxas de variação e correntes iônicas utilizadas no modelo de célula ganglionar. A última coluna da tabela contém as referências de onde as equações foram retiradas ou adaptadas.

Tabela 14. Parâmetros utilizados no modelo da célula ganglionar para as taxas de variação, condutâncias máximas e correntes iônicas. A última coluna da tabela contém as referências de onde os parâmetros foram retirados ou adaptados.

Tabela 15. Parâmetros utilizados na modelagem dos canais sinápticos. 46

Tabela 16. Densidades dos fotorreceptores para uma região a $2^{\circ}$ de excentricidade da area centralis. O número de neurônios indicado em cada caso é referente a uma região de $1 \mathrm{~mm} 2$. Dados retirados de STERLING et al., 1988.

Tabela 17. Conexões estimadas nos circuitos primário e secundário para uma região a $2^{\circ}$ de excentricidade da area centralis. Dados adaptados de STERLING et al., 1988. 
Tabela 18. Condutâncias das sinapses elétricas presentes no modelo dos circuitos primário e secundário. 


\section{Abstract}

Title: A computational study on the influence of rod coupling by electrical synapses on the scotopic dynamic range of the vertebrate retina

Recent studies suggest the existence of electrical synapses (gap junctions) connecting photoreceptors in the vertebrate retina. In this work we describe a computer model of the primary and secondary rod pathways in the vertebrate retina. The model is composed of the following cell populations: rods, cones, rod bipolar cells, cone bipolar cells, All amacrine cells and ganglion cells. Cells of the model are connected via chemical as well as electrical synapses according to realistic convergence and divergence factors. There are electrical synapses between rods, rods and cones, All amacrine cells, and cone bipolar cells and All amacrine cells. The model assumes that low intensity stimuli simulating scotopic conditions reach all rods in the receptor array but less than half of them are excited. The excited rods response is controlled by a photocurrent waveform whose amplitude can be manipulated to simulate stimuli of different intensities within the scotopic range. The model is used to investigate the effects of different degrees of coupling among photoreceptors and among All amacrine cells, as well as values of rod hyperpolarization activated current $I_{h}$ on the dynamic range of the retina. Results show that for realistic values of $I_{h}$ conductance the dynamic range of the rod array is maximized at the critical connectivity degree for bond percolation. However, the dynamic range of the rod bipolar and ganglion cells is maximized for a photoreceptor connectivity degree below the critical value. The latter result is a consequence of the high convergence of chemical synapses from rods to rod bipolar cells.

Keywords: Dynamic Range; Gap Junctions; Retina; Scotopic Vision; Compartmental Modeling. 


\section{Resumo}

Recentes estudos sugerem a existência de sinapses elétricas mediadas por junções gap entre fotorreceptores na retina de vertebrados. Neste trabalho, descrevemos um modelo computacional dos circuitos primário e secundário mediados pelos bastonetes da retina de vertebrados. O modelo é composto pelas seguintes populações de células: bastonetes, cones, células bipolares dos bastonetes, células bipolares dos cones, células amácrinas do tipo All e células ganglionares. As células do modelo estão acopladas entre si por sinapses químicas e elétricas segundo padrões realísticos de convergência e divergência. As sinapses elétricas ocorrem entre os bastonetes, entre os bastonetes e os cones, entre as células amácrinas All e entre as células bipolares dos cones e a células amácrinas All. O modelo assume que um estímulo luminoso de baixa intensidade, simulando condições escotópicas, atinge todos os bastonetes da camada receptora, porém menos da metade deles é excitada. A resposta dos bastonetes excitados é controlada por uma fotocorrente cuja amplitude pode ser alterada para simular estímulos de diferentes intensidades dentro da faixa escotópica. O modelo é utilizado para investigar os efeitos dos diferentes graus de acoplamento elétrico entre as células receptoras e entre as células amácrinas All, além do efeito de diferentes valores de condutância do canal $I_{h}$ ativado pela hiperpolarização nos bastonetes, sobre a faixa dinâmica da retina. Os resultados das simulações mostram que, para valores realísticos da condutância do canal $I_{h}$, a faixa dinâmica medida na camada receptora é maximizada para o índice de conectividade crítico para que haja percolação de ligação. No entanto, quando a faixa dinâmica é medida para as células bipolares ou ganglionares o valor máximo é obtido para um índice de conectividade subcrítico. Este resultado é conseqüência da alta convergência de sinapses químicas entre os bastonetes e células bipolares. 
“As grandes comportas do mundo maravilhoso se abriram.” Herman Melville, Moby Dick (Capítulo I) 

Estudo computacional sobre a influência de sinapses elétricas entre bastonetes na faixa dinâmica escotópica da retina de vertebrados

\section{Capítulo I}

\section{Introdução}

O conhecimento do ambiente externo é feito pelo nosso organismo através de órgãos dos sentidos adaptados para responder a diversas influências do ambiente e transmitir essa informação ao sistema nervoso central. Dentre as diferentes modalidades sensoriais destacaremos neste trabalho os primeiros estágios do processamento visual na retina de vertebrados. A retina é um dos principais sistemas estudados pela neurociência devido à importância da visão para os seres humanos e à riqueza intrínseca de seus circuitos neurais (STERLING \& DEMB, 2004). A primeira etapa do processamento visual nos vertebrados ocorre na retina, que, de forma semelhante a outras modalidades sensoriais, possui circuitos que transmitem os estímulos de forma direta e em paralelo, bem como conexões laterais mediadas por sinapses elétricas e químicas (DUDEL, 1977 ;SHEPHERD \& KOCH, 2004). O padrão de conectividade entre os neurônios da retina pode estar relacionado com o fato de que o sistema visual é capaz de responder a estímulos luminosos de intensidades bem diversas. Para que possamos responder a uma larga faixa de intensidade de estímulos luminosos, é necessário que a primeira estrutura que processa esses estímulos tenha sua circuitaria organizada de tal forma a amplificar sua faixa dinâmica de resposta em relação às dos neurônios que a constituem, pois estes têm, em geral, faixas dinâmicas restritas (BARLOW, 1982). Os mecanismos responsáveis por esse aumento na faixa dinâmica na retina de vertebrados ainda não são bem conhecidos e serão investigados neste trabalho.

Um dos estudos pioneiros sobre a retina de vertebrados foi realizado em 1938, envolvendo medidas de sinais de uma única fibra do nervo ótico de um sapo quando seu olho era estimulado com pontos luminosos (HARTLINE, 1938). Nesse trabalho, Hartline cunhou o termo campo receptivo (CR) para descrever uma área da retina na qual qualquer alteração na iluminação afetaria a taxa basal de disparo medida em uma determinada fibra do nervo ótico. Além disso ele encontrou três tipos de campo receptivo no sapo, denominados de ON, ON/OFF e OFF, todos com nomenclatura relacionada com a apresentação do estímulo (ON) ou com a retirada do mesmo (OFF). Em 1953, Barlow observou que a resposta do campo receptivo de tipo OFF ocorria 
tanto no seu centro como na sua periferia, diferentemente do caso para o campo receptivo de tipo ON/OFF cuja resposta era dada pela diferença entre as suas regiões central e periférica (BARLOW, 1953). Através desses trabalhos com a retina, ficou demonstrado que cada fibra do nervo ótico envia para o cérebro informações sobre onde e quando houve a apresentação de um estímulo $(\mathrm{ON})$, onde o estímulo foi interrompido (OFF) ou onde existe movimento (ON/OFF). Somente em 1959 foi demonstrado que a retina do sapo poderia enviar informações mais complexas para o cérebro do que simplesmente operações do tipo ON, OFF ou ON/OFF através da utilização de objetos contrastantes como estímulo ao invés de pontos luminosos (LETTVIN, et al, 1959). Canais visuais paralelos, ON para o processamento de sinais luminosos com sobre fundos escuros e OFF para a distinção de áreas escuras sobre fundos claros são qualidades essenciais, já que a visão de vertebrados depende basicamente da percepção de contraste entre as imagens e seus fundos.

O principal foco deste trabalho é o estudo dos circuitos que envolvem o processamento de sinais escotópicos na retina, ou seja, de baixa intensidade luminosa sobre um fundo escuro, cobrindo uma faixa de valores de intensidade que vai aproximadamente da luz das estrelas à luz do crepúsculo (SMITH \& VARDI, 1995), além de uma investigação dos mecanismos responsáveis pelo aumento da faixa dinâmica de resposta aos estímulos luminosos.

Um dos mecanismos utilizados pela retina para operar em condições de luminosidade tão distintas é a segregação do sinal em diversas vias, todas convergindo para os diversos tipos de células ganglionares. Além das descobertas sobre os diferentes campos receptivos das células ganglionares e de circuitos mediados por cones e bastonetes, recentes trabalhos experimentais apontam a existência de circuitos alternativos ao circuito primário dos bastonetes para condições de baixa luminosidade (DEANS et al., 2002; VOLGYI et al., 2004). A existência de múltiplos circuitos mediados pelos bastonetes é possível devido a presença de sinapses elétricas mediadas por junções gap nesses circuitos, sugerindo uma importante função para esse tipo de comunicação entre as células da retina. A necessidade de amplificação da faixa dinâmica de resposta pela retina e os recentes trabalhos sobre a presença de junções gap em várias camadas sugerem que o acoplamento das células da retina por junções gap possa ter algum papel sobre os mecanismos de aumento da faixa dinâmica, abrindo um 
Estudo computacional sobre a influência de sinapses elétricas entre bastonetes na faixa dinâmica escotópica da retina de vertebrados

caminho para a investigação desse aumento da faixa dinâmica em termos de um fenômeno coletivo e não individual (COPELLI et al., 2005).

Neste trabalho foi realizada uma análise detalhada da influência das sinapes elétricas mediadas por junções gap e de mecanismos intracelulares sobre a faixa dinâmica da visão escotópica da retina, através da modelagem dos processos biofísicos existentes em cada neurônio e da simulação computacional de um modelo das vias dos bastonetes na retina, possibilitando a caracterização dos mecanismos envolvidos e a determinação do efeito de alguns parâmetros específicos. O uso de um modelo computacional permite a realização de estudos impossíveis ou muito difíceis de serem realizados experimentalmente, como a geração de uma população de modelos idênticos a menos de um parâmetro que pode ser variado sistematicamente para se determinar seu efeito, ou o estudo da relação entre um mecanismo intracelular e o comportamento coletivo dos neurônios. Apesar de tal estudo poder, em princípio, ser feito com um modelo simplificado (HENNIG et al., 2002), a construção de um modelo biologicamente detalhado como o deste trabalho permite um maior grau de aprofundamento sobre os aspectos biofísicos envolvidos.

Os próximos capítulos apresentarão detalhes dos modelos individuais de neurônios utilizados e dos principais circuitos $\mathrm{ON}$ mediados pelos bastonetes, além de um estudo detalhado sobre a configuração de parâmetros ideal da rede para se obter uma larga faixa dinâmica de resposta escotópica da retina. Nos próximos capítulos, uma revisão dos principais trabalhos experimentais e teóricos que serviram como base para a construção do modelo é realizada, bem como a descrição completa das estratégias empregadas para análise dos resultados e uma comparação destes com os dados experimentais apresentados na literatura.

No capítulo II é feita uma breve apresentação dos conceitos mais importantes utilizados neste trabalho, além de uma revisão dos principais aspectos celulares, do padrão de conectividade e da estrutura da retina de vertebrados. Além disso, são discutidas as principais teorias e resultados experimentais relacionados à presença de sinapses elétricas nas primeiras etapas do processamento visual.

O capítulo III aborda a descrição completa das equações e parâmetros dos modelos compartimentais dos neurônios simulados, receptores sinápticos e dos padrões de convergência e divergência do modelo de rede. A escolha dos parâmetros é discutida e justificada de acordo com as referências experimentais disponíveis. Além disso, neste 
capítulo o sistema de estimulação e os modelos de sinapses utilizados nas simulações são descritos em detalhes.

No capítulo IV os principais resultados gerados pelo modelo são apresentados e discutidos. O modelo foi submetido a quatro experimentos com o objetivo de se analisar os mecanismos intracelulares e de cada etapa do circuito responsáveis pelo aumento da faixa dinâmica da rede. O primeiro experimento foi realizado para verificar o efeito da corrente ativada pela hiperpolarização no potencial de membrana do bastonete e na faixa dinâmica do neurônio isolado. O segundo experimento foi elaborado para se investigar o comportamento do modelo da camada receptora quando os fotorreceptores são acoplados por sinapses elétricas e submetidos a um protocolo de estimulação baseado na fotocorrente gerada pelo mecanismo de transdução. Este experimento possibilita investigar se existe algum mecanismo de aumento na faixa dinâmica já na camada receptora ou se isso ocorre após a convergência dos receptores para as camadas posteriores. No terceiro experimento, um protocolo de estimulação semelhante ao realizado no experimento anterior é aplicado em uma rede de duas camadas, composta por bastonetes e células bipolares, com a adição de um mecanismo de saturação pela presença de sinapses químicas entre os dois tipos de neurônios. O quarto e último experimento foi realizado para verificar o efeito das sinapses elétricas nos circuitos primário e secundário da retina, ambos convergindo para as células ganglionares. Este experimento envolveu todo o modelo da retina e possibilitou uma análise detalhada da influência de mecanismos da rede e intracelulares no aumento da faixa dinâmica em cada camada intermediária e na camada de saída da retina composta pelas células ganglionares.

No capítulo V são discutidas as principais aproximações adotadas na implementação do modelo e suas possíveis relações com os resultados obtidos. O modelo mostrou-se capaz de replicar os principais resultados experimentais das células individuais e o padrão de conectividade observado experimentalmente. Os resultados obtidos nas simulações mostram que o acoplamento de fotorreceptores por sinapses elétricas na camada receptora da retina de vertebrados pode aumentar a faixa dinâmica escotópica da rede. Essa amplificação acontece quando os fotorreceptores estão acoplados com um grau de conectividade abaixo do valor crítico para a ocorrência de percolação de ligação. A amplificação só ocorre na criticalidade quando o fator de convergência entre 
Estudo computacional sobre a influência de sinapses elétricas entre bastonetes na faixa dinâmica escotópica da retina de vertebrados

bastonetes e células bipolares é reduzido, sugerindo que uma alta convergência entre essas duas populações de neurônios pode provocar uma saturação antecipada na rede. 


\section{Capítulo II}

\section{Revisão}

A construção de um modelo computacional biologicamente plausível, ou realista, de um neurônio ou sistema completo requer uma grande quantidade de informações sobre mecanismos ativos e passivos, morfologia, fisiologia e arquitetura da célula e da rede. Muito antes da implementação do modelo matemático em uma determinada linguagem de programação, vem a etapa de compilação dos dados disponíveis na literatura sobre as estruturas e mecanismos que serão investigados. Esta compilação de informações é essencial na modelagem realística para garantir que o modelo possua mecanismos com características similares às observadas nos sistemas biológicos e seja capaz de produzir respostas semelhantes as obtidas experimentalmente.

Neste capítulo é apresentada uma revisão sobre os dados relativos aos neurônios, elementos essenciais na construção do modelo desta tese, sobre as estruturas que compõem a retina e sobre os principais modelos matemáticos utilizados para descrever o comportamento dos mecanismos ativos presentes nos neurônios que compõem cada uma das camadas na estrutura laminar da retina. A maior parte dos dados sobre neurônios, arquitetura da rede, padrões de conexão e mecanismos sinápticos contidos nesta revisão vem de trabalhos experimentais em ratos ou salamandras. Ao longo do texto serão citadas todas as referências experimentais relativas a cada mecanismo abordado neste capítulo.

\section{Equação de membrana e formalismo de Hodgkin-Huxley}

A descrição elétrica mais simples possível de uma pequena região da membrana celular, apenas com mecanismos passivos, possui três componentes: a resistência de membrana $\mathrm{R}$ ou resistência específica de membrana $\mathrm{R}_{\mathrm{m}}$ dada pelo produto entre resistência de membrana e área, a capacitância de membrana $\mathrm{C}$ ou a capacitância específica de membrana $\mathrm{C}_{\mathrm{m}}$ dada pela divisão da capacitância de membrana pela área $\mathrm{e}$ o potencial da célula em equilíbrio dinâmico chamado potencial de repouso $V_{\text {rep. }}$. Desta 
Estudo computacional sobre a influência de sinapses elétricas entre bastonetes na faixa dinâmica escotópica da retina de vertebrados

forma, a corrente de membrana ou corrente que é injetada na célula pode ser dada pela soma das correntes capacitiva e resistiva, conforme mostra a equação 1 (KOCH, 1999):

$$
I_{i n j}(t)=C \frac{d V_{m}(t)}{d t}+\frac{V_{m}(t)-V_{r e p}}{R}
$$

onde $V_{m}$ é o potencial de membrana em um dado instante de tempo t. A mesma equação reescrita em termos da constante de tempo $\tau$ é chamada de equação de membrana da célula (equação 2) e sua solução permite dizer como o potencial de membrana varia com o tempo em relação ao potencial de repouso.

$$
\tau \frac{d V_{m}(t)}{d t}=-V_{m}(t)+V_{r e p}+R I_{i n j}
$$

Este modelo baseado em um circuito RC acrescido de um limiar de resposta já constitui um modelo simplificado de neurônio, conhecido como modelo integra $e$ dispara com vazamento (KOCH, 1999).

Um modelo mais realista de neurônio leva em consideração que a membrana possui condutâncias iônicas variáveis no tempo em função do potencial de membrana (HODGKIN \& HUXLEY, 1952). Escrevendo a equação de membrana em termos da capacitância e da condutância específica dada por $G_{m}=\frac{1}{R_{m}}$, pode-se escrever uma única equação diferencial que envolva as propriedades passivas descritas anteriormente e as correntes iônicas atravessando a membrana celular. Desta forma, adicionando um termo à equação de membrana relativo a contribuição de diferentes correntes iônicas, temos:

$$
C_{m} \frac{d V_{m}(t)}{d t}=-\sum I_{i o ̂ n i c a s}-I_{v a z}+I_{i n j}
$$

onde o somatório representa a soma de todas as correntes iônicas que entram na célula e $I_{v a z}$ representa a corrente de vazamento que flui passivamente através da membrana. Cada uma das correntes iônicas iônicas presentes na célula se relaciona com o potencial 
de reversão do íon específico, dado pela equação de Nernst (HILLE, 2001), e com o potencial de membrana segundo a relação:

$$
I_{\text {iônica }}(t)=G_{\text {ion }}\left(V_{m}(t), t\right)\left(V_{m}(t)-E_{\text {ion }}\right)
$$

onde $G_{i o n}$ representa a condutância específica de membrana de um determinado íon e $E_{i o n}$ é o potencial de reversão calculado através da equação de Nernst. Desconsiderando a natureza estocástica das transições entre estados abertos e fechados dos canais iônicos, a condutância $G_{\text {ion }}$ pode ser descrita, de forma geral, como:

$$
G_{i o n}=G_{\max } m^{a} h^{b}
$$

onde $G_{m a x}$ representa a condutância máxima da população de canais e o produto $m^{a} h^{b}$ representa a proporção média de canais abertos. De acordo com o formalismo empregado nos trabalhos de Hodgkin e Huxley para o axônio gigante de lula, $m$ representa a probabilidade de uma partícula ou portão estar no estado aberto enquanto $h$ representa a probabilidade desta partícula ou portão estar no estado fechado, conforme a representação na figura 1 . Os expoentes $a$ e $b$ indicam o número de estados ativados ou inativados por canal. Os canais podem estar parcialmente $(0<m<1)$ ou completamente ativados ( $m=1)$; inativados $(h=0)$ ou desinativados $(h=1)$. Alguns canais não possuem estados de inativação ( $b=0$ ) e resultam em correntes persistentes. Em contraste, canais que inativam resultam em correntes transientes (IZHIKEVICH, 2006). As equações que descrevem a dinâmica dos portões $m$ e $h$ serão descritas nos próximos parágrafos e utilizadas em todos os modelos de canais iônicos deste trabalho, da mesma forma que as equações 3 e 4 .

A dinâmica das variáveis de ativação e inativação $m$ e $h$ pode ser descrita pelas seguintes equações diferenciais de primeira ordem:

$$
\frac{d m}{d t}=\frac{m_{\infty}(V)-m}{\tau(V)} \quad \text { e } \quad \frac{d h}{d t}=\frac{h_{\infty}(V)-h}{\tau(V)}
$$

onde $m_{\infty}$ e $h_{\infty}$ representam os valores assintóticos da condutividade para um determinado valor de potencial de membrana e $\tau(\mathrm{V})$ é a constante de tempo relativa à variável $m$ ou $h$. Os valores assintóticos e as constantes de tempo das variáveis de ativação ou inativação podem ser obtidos experimentalmente. As funções que 
Estudo computacional sobre a influência de sinapses elétricas entre bastonetes na faixa dinâmica escotópica da retina de vertebrados

representam os valores assintóticos da condutividade podem ainda ser descritas em termos das taxas de transição entre os estados aberto $(\alpha)$ e fechado $(\beta)$ de um canal, conforme mostram as equações 7 e 8 .

$$
\begin{array}{lll}
\frac{d m}{d t}=\frac{m_{\infty}(V)-m}{\tau(V)} & \text { e } & h_{\infty}(V)=\frac{\alpha_{h}}{\alpha_{h}+\beta_{h}} \\
\tau_{m}(V)=\frac{1}{\alpha_{m}+\beta_{m}} & \text { e } & \tau_{h}(V)=\frac{1}{\alpha_{h}+\beta_{h}}
\end{array}
$$

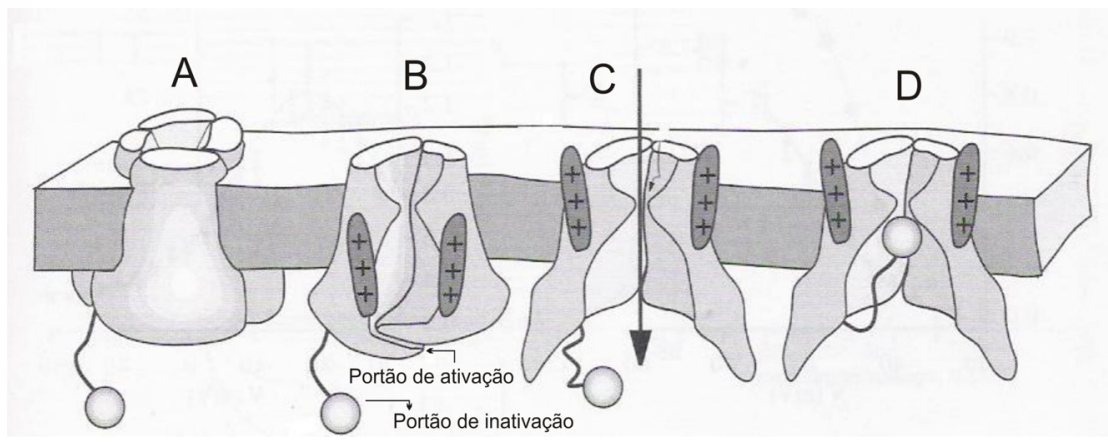

Figura 1. Estrutura dos canais iônicos dependentes do potencial de membrana. Em (A) e (B) o canal não está ativado, até que sensores do potencial permitem a abertura do portão de ativação, permitindo a passagem de íons em (C). Em seguida o portão de inativação bloqueia o canal em (D). Figura adaptada de IZHIKEVICH, 2006.

As funções $m_{\infty}$ e $h_{\infty}$ possuem forma sigmoidal e podem ser descritas por uma função de Boltzmann (equação 9), enquanto a função $\tau(V)$ possui forma unimodal e pode ser descrita por uma gaussiana (equação 10). O ajuste dos parâmetros indicados nas equações 9 e 10 de acordo com as curvas obtidas experimentalmente permite a obtenção das equações necessárias para a modelagem da dinâmica de cada canal iônico. Todas as correntes iônicas modeladas neste trabalho foram obtidas a partir dos dados experimentais disponíveis na literatura, onde as variáveis de ativação e inativação foram obtidas conforme a descrição dada nas equações 9 e 10. 


$$
\begin{aligned}
& m_{\infty}(V)=\frac{1}{1+\exp \left\{\frac{\left(V-V_{1 / 2}\right)}{k}\right\}} \\
& \tau(V)=C_{\text {base }}+C_{\text {amp }} \exp \left\{\frac{-\left(V_{\text {max }}-V\right)^{2}}{\sigma^{2}}\right\}
\end{aligned}
$$

Nestas equações, $V_{1 / 2}$ satisfaz a condição $m_{\infty}\left(V_{1 / 2}\right)=0,5$ e $k$ é o fator de inclinação. Para a constante de tempo $\tau$ temos uma gaussiana de amplitude $\mathrm{C}_{\text {amp }}$ acima de um valor $\mathrm{C}_{\text {base }}$ e pico em $V_{\max }$. O parâmetro $\sigma$ é o desvio padrão da gaussiana.

A cada passo de uma simulação de um neurônio a equação de membrana representada em 3 é integrada para cada compartimento em que o neurônio é dividido, com a sua configuração específica de íons. A descrição completa das correntes iônicas utilizadas e da dinâmica de cada canal é realizada no próximo capítulo.

\section{Faixa dinâmica de resposta}

Os seres vivos geralmente respondem a estímulos sensoriais cujas intensidades podem variar, no caso do sistema visual, desde um único fóton até centenas de fótons por $\mu \mathrm{m}^{2}$ (RISPOLI, 1998). Para prevenir a saturação para estímulos de alta intensidade sem perder a sensibilidade a estímulos de baixa intensidade é necessário que exista algum mecanismo de aumento da faixa dinâmica logo nos primeiros estágios de processamento pelos sistemas sensoriais, como a retina, por exemplo, no caso do sistema visual (COPELLI et al., 2005).

Uma das formas de se quantificar a resposta de um neurônio isolado ou de uma rede de neurônios a estímulos de intensidades variáveis é através da chamada curva $F x I$ do sistema (figura 2). Para um neurônio isolado, a curva $F x I$ dá a freqüência de disparos $F$ do neurônio em função da intensidade $I$ do estímulo. A freqüência é calculada dividindo-se por um período de tempo suficientemente longo o número de disparos emitidos pelo neurônio durante este período. Para uma rede de neurônios, a curva FxI é determinada pela quantidade de disparos emitidos por todos os neurônios da rede durante um período de tempo dividida pelo número de neurônios na rede multiplicado pelo período de tempo. O comportamento típico de uma curva $F x I$ é do tipo sigmoidal (figura 2), com uma freqüência mínima para estímulos de baixas intensidades e uma 
Estudo computacional sobre a influência de sinapses elétricas entre bastonetes na faixa dinâmica escotópica da retina de vertebrados

freqüência máxima de saturação para estímulos de intensidades muito altas. É a partir dessa curva que se define a faixa dinâmica do sistema.

Não existe um consenso na literatura sobre como estimar a faixa dinâmica. Alguns autores se referem a este conceito como sinônimo de faixa operacional, definida como a faixa de valores de estímulos para os quais a taxa de disparos do neurônio ou da rede continua a aumentar sem que exista saturação (SMITH \& BRACHMAN, 1980). A faixa dinâmica deve sempre se referir a uma faixa de estímulos que se localiza entre os pontos logo acima do menor nível de resposta do sistema e logo abaixo do primeiro ponto em que há uma saturação na resposta. Se o nível de estímulo que produz a resposta de menor freqüência for representado por $\varepsilon$, então $\varepsilon+\Delta$ representará o nível de saturação, onde $\Delta$ representa a faixa de resposta, conforme representado na figura 2 .

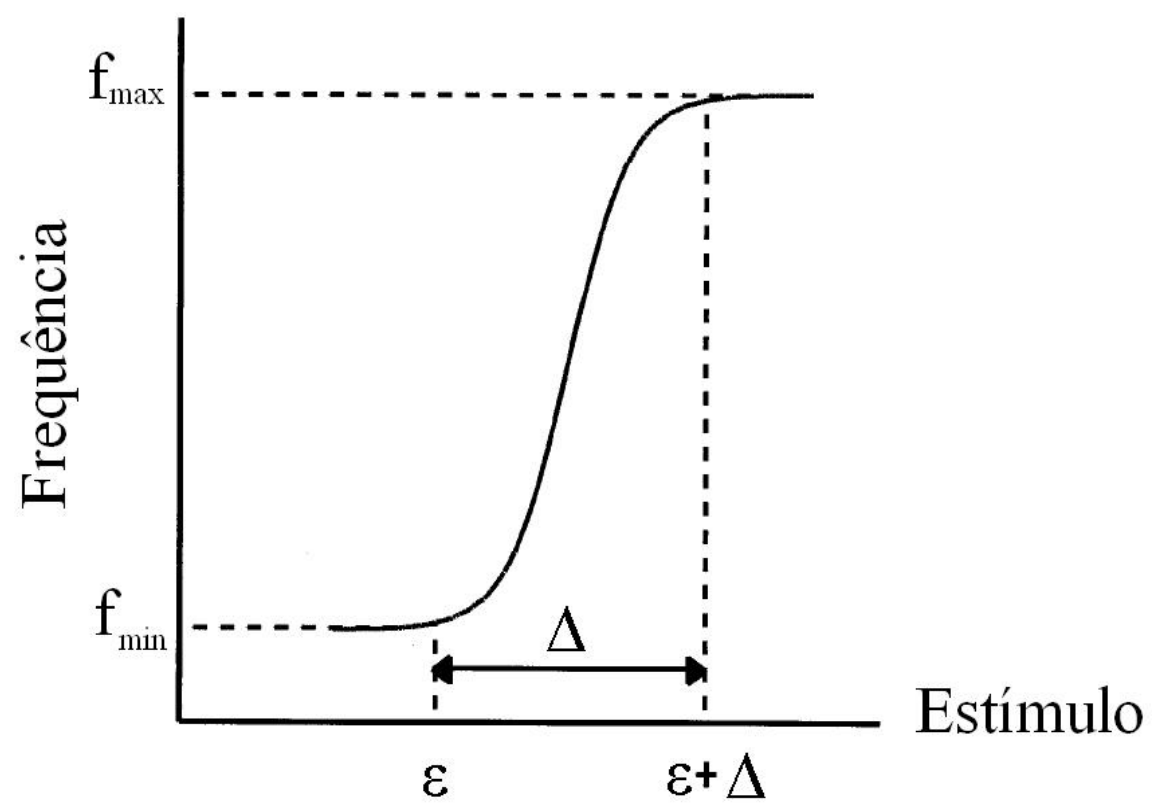

Figura 2. Curva FxI em unidades arbitrárias de estímulo e freqüência. A faixa dinâmica é indicada por $\Delta$ e a intensidade do estímulo para a qual a freqüência começa a aumentar a partir do valor mínimo é indicada por $\varepsilon$. As freqüências $f_{\min }$ e $f_{\max }$ indicam, respectivamente, o limiar de resposta e o ponto de saturação. Figura adaptada de NIZAMI, 2002.

O valor da faixa dinâmica depende substancialmente da forma como são definidos os extremos representados na figura 2, dificultando a comparação entre faixas dinâmicas calculadas de formas diferentes. Neste trabalho foi utilizada uma mesma definição de faixa dinâmica em todas as camadas da retina e experimentos realizados, 
possibilitando uma comparação entre os resultados (COPELLI, 2007). Para os neurônios isolados e para diferentes camadas, a faixa dinâmica em decibéis é dada por :

$$
\Delta=10 \log \left(\frac{I_{90}}{I_{10}}\right)
$$

onde $I_{90}$ e $I_{10}$ representam, respectivamente, os valores do estímulo para os o sistema apresenta respostas $10 \%$ abaixo da máxima e $10 \%$ acima da mínima. No caso dos neurônios que possuem uma linha base, representada por $f_{\min }$, não nula, pode-se definir de uma forma geral quais serão os valores para $I_{90}$ e $I_{10}$. Para isso basta determinar os valores de $f_{90}$ e $f_{10}$ das freqüências de disparo usando a seguinte relação (COPELLI et al., 2005):

$$
F_{x}=F_{0}+x\left(F_{\max }-F_{0}\right)
$$

onde $x$ pode representar os pontos $10 \%$ abaixo da intensidade máxima ou $10 \%$ acima da intensidade mínima, enquanto $F_{0}$ e $F_{\max }$ representam as respostas mínima e máxima respectivamente. No caso de neurônios que não emitem potenciais de ação, como todos os neurônios da retina com exceção das células ganglionares, a mesma definição de faixa dinâmica pode ser usada com os potenciais de membrana das células, $V_{90}$ e $V_{10}$, sendo usados no lugar das freqüências de disparo.

\section{Sinapses elétricas}

Durante algum tempo as fortes evidências experimentais a respeito da transmissão sináptica por meio de sinapses químicas eram generalizadas e consideradas como a principal, senão a única, forma de transmissão de sinais existente no sistema nervoso. Somente após a descoberta da existência de sinapses elétricas no sistema motor de lagostim, onde foi mostrado que a transmissão de sinais da célula pré sináptica para a célula pós sináptica levava apenas uma fração de milissegundo, é que passou a ser aceita a idéia de que mecanismos elétricos e químicos contribuem para a comunicação entre células (FURSHPAN \& POTTER, 1959;BENNETT, 1997;BENNET, 2000). A comunicação entre duas células através de sinapses elétricas ocorre com uma separação da ordem de 2-4 nm, uma separação aproximadamente dez vezes menor que na 
Estudo computacional sobre a influência de sinapses elétricas entre bastonetes na faixa dinâmica escotópica da retina de vertebrados

transmissão por sinapses químicas, cuja fenda sináptica é da ordem de $20 \mathrm{~nm}$. Nessa região de separação, as duas células se comunicam através de poros chamados de junções gap formados por proteínas chamadas conexinas $(\mathrm{Cx})$ que funcionam como dutos para a corrente iônica (SAEZ et al., 2003), conforme representado na figura 3.

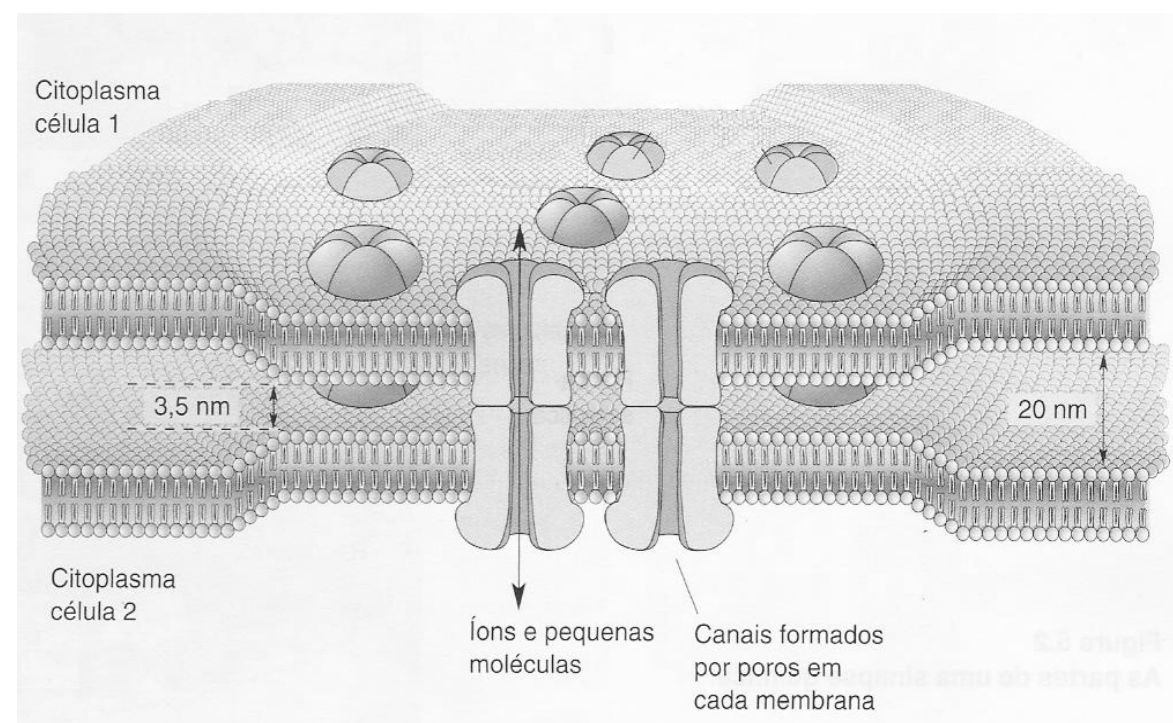

Figura 3. Terminais sinápticos de duas células conectadas por junções gap. As conexinas são representadas conectando os citoplasmas das duas células. No caso de uma sinapse bi-direcional, os íons e pequenas moléculas podem passar em ambos sentidos. Figura adaptada de BEAR et al., 2002.

Como o único obstáculo para o fluxo de corrente entre duas células acopladas é a resistência provocada pelos poros que as unem, esse fluxo pode ocorrer em ambas as direções. Esta possibilidade de comunicação em duas vias juntamente com a transmissão independentemente de um limiar de resposta são características exclusivas das sinapses elétricas. Apesar de grande parte do acoplamento elétrico existente ser bidirecional, alguns tipos de sinapses elétricas são retificadoras, ou seja, permitem a passagem da corrente oferecendo menor resistência em uma direção do que na outra (FURSHPAN \& POTTER, 1959).

Muitas das primeiras descobertas da presença junções gap entre neurônios do sistema nervoso central foram realizadas na retina, que continua sendo um dos melhores sistemas biológicos para o estudo desse tipo de sinapse por possuir acoplamento elétrico na maioria de seus circuitos e por apresentar junções gap nos primeiros estágios do desenvolvimento neuronal e em animais adultos (DOWLING, 1987). A maior parte das junções gap presentes na retina de mamíferos é constituída por uma classe específica da família das conexinas, a conexina 36 (Cx36) (MILLS \& MASSEY, 2000 ; DEANS et 
al., 2002). Na retina de mamíferos, a Cx36 pode ser encontrada entre células amácrinas do tipo AII que participam dos circuitos mediados pelos bastonetes, entre cones e bastonetes e entre células bipolares do cone e células amácrinas do tipo AII (DEANS et al., 2002).

Apesar da função exata das sinapses elétricas na retina não ser bem conhecida, sabese que esse tipo de comunicação é essencial tanto sob condições de alta quanto baixa luminosidade pelo fato de as junções gap estarem presentes nos circuitos mediados tanto por cones como por bastonetes. Algumas possíveis funções para as sinapses elétricas já foram bastante estudadas, como o efeito do acoplamento entre fotorreceptores sobre a relação sinal/ruído da rede, o efeito do acoplamento entre células horizontais sobre o mecanismo de inibição lateral e o efeito do acoplamento entre células amácrinas do tipo AII (TESSIER-LAVIGNE \& ATTWELL, 1988; SMITH \& VARDI, 1995).

O modelo de retina apresentado neste trabalho simula a presença de sinapses elétricas, de acordo com as evidências experimentais apresentadas anteriormente, entre células da camada receptora, entre células amácrinas de tipo AII e entre células bipolares do cone e células amácrinas de tipo AII. Segundo uma conjectura proposta inicialmente por COPELLI et al. (2002) e desenvolvida em trabalhos subseqüentes (COPELLI et al., 2005; KINOUCHI \& COPELLI, 2006), o acoplamento de neurônios sensoriais receptores por sinapses elétricas provoca um aumento na sua faixa dinâmica em relação ao caso desacoplado. O mais recente desses trabalhos (KINOUCHI \& COPELLI, 2006), em que ferramentas da física estatística foram usadas para estudar uma rede bidimensional de elementos excitáveis acoplados por sinapses elétricas, sugere que o aumento da faixa dinâmica é máximo quando o grau de acoplamento entre os neurônios corresponde a um ponto crítico de uma transição de fase da rede.

\section{Retina}

A retina é uma fina camada de tecido neural com aproximadamente $0,4 \mathrm{~mm}$ de espessura posicionada na parte posterior do globo ocular. Basicamente a retina é composta por cinco grandes grupos celulares (fotorreceptores, células horizontais, bipolares, amácrinas e ganglionares), classificados de acordo com sua morfologia, fisiologia e posição nos diferentes circuitos que compõem essa região. Apesar de 
Estudo computacional sobre a influência de sinapses elétricas entre bastonetes na faixa dinâmica escotópica da retina de vertebrados

existirem algumas variações, existe uma uniformidade muito grande na retina de vertebrados. As principais classes de neurônios e o mecanismo de transdução da luz são comuns a todos os vertebrados (RODIECK, 1988). Os fotorreceptores são divididos entre cones e bastonetes nos vertebrados e são estimulados por fótons, sendo que os bastonetes participam dos circuitos da retina responsáveis pelo processamento de sinais sob baixas intensidades luminosas (escotópicos), e os cones participam dos circuitos da retina responsáveis pelo processamento de sinais sob altas intensidades luminosas e são os responsáveis pela visão em cores. As células ganglionares representam a única saída da retina e seus dendritos penetram nas camadas mais internas, onde recebem contatos sinápticos excitatórios das células bipolares e células amácrinas. Estas duas últimas classes de células se conectam umas às outras por meio de células horizontais e recebem os sinais dos cones e bastonetes (STERLING, 1998). Na retina de vertebrados, os corpos celulares dos neurônios estão agrupados em três camadas distintas que recebem os nomes de camada nuclear externa, camada nuclear interna e camada de células ganglionares. Essas camadas são separadas pelas camadas plexiformes que não possuem nenhum tipo de corpo celular mas são ricas em contatos sinápticos, conforme a descrição na figura 4.

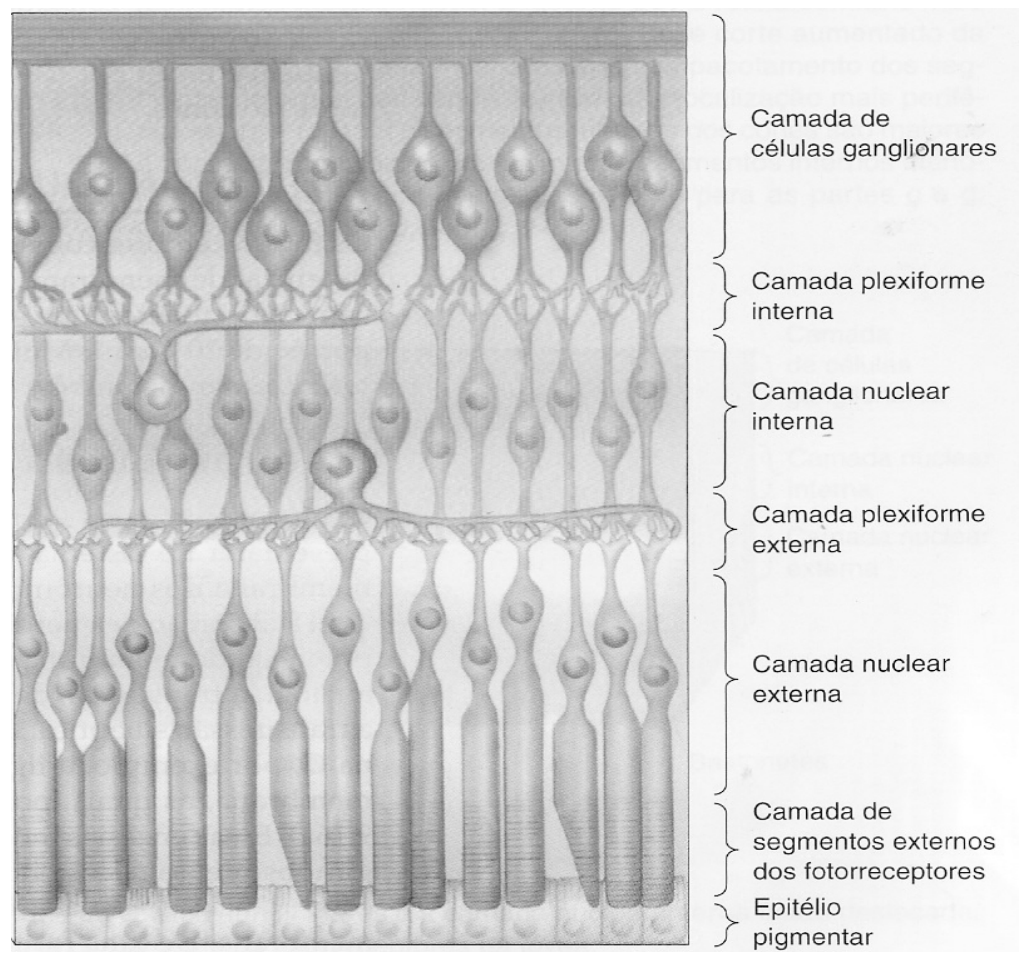


Figura 4. Organização laminar da retina. A luz que incide na retina atravessa todas as camadas até atingir o epitélio pigmentar, onde estão contidos os segmentos externos dos fotorreceptores. A única saída da retina é através da células ganglionares. Figura adaptada de BEAR et al., 2002.

Conforme representado na figura 4, os segmentos externos dos fotorreceptores estão contidos no epitélio pigmentar, responsável pela regulação iônica e por evitar a reflexão da luz no interior do globo ocular. Cada fotorreceptor converte o estímulo luminoso em sinais que são transmitidos para a camada nuclear interna, para os vários tipos de células bipolares ou horizontais. $\mathrm{Na}$ sinapse existente entre os receptores e as celulas bipolares também estão presentes contatos com as células horizontais, que juntamente com as células amácrinas são responsáveis pelas conexões laterais na retina.

\section{Camada nuclear externa}

A camada nuclear externa da retina de vertebrados é composta por pelo menos dois tipos de fotorreceptores, cones e bastonetes. A estrutura de ambos é bastante semelhante, sendo composta de um segmento externo com aproximadamente 900 discos membranosos responsáveis pela absorção da luz e o segmento interno com a organelas celulares (STERLING, 1998). Os bastonetes são os receptores adaptados para operar em condições de baixa intensidade luminosa enquanto os cones são adaptados para operar em condições de alta intensidade luminosa. Os mamíferos possuem, além de um único tipo de bastonete, dois tipos de cones especializados em faixas distintas do espectro luminoso e nomeados cones verdes ou azuis. Essa nomenclatura é relacionada com o comprimento de onda do pico da curva de absorção de cada um dos cones, 550 $\mathrm{nm}$ para o caso dos cones verdes e $450 \mathrm{~nm}$ para o caso dos cones azuis (JACOBS, 1993). Os primatas possuem ainda um terceiro tipo de cone, o cone vermelho relacionado com um pico de absorção na faixa de $570 \mathrm{~nm}$.

A principal função dos receptores é a de converter o estímulo luminoso e transmitir esse sinal para as células bipolares e horizontais. Cones e bastonetes respondem a um estímulo luminoso com uma hiperpolarização de membrana, o que provoca uma redução na concentração de glutamato liberado e uma despolarização de membrana em alguns tipos de células bipolares. A hiperpolarização de membrana gerada pela absorção dos fótons é resultante do fechamento dos canais iônicos no segmento externo dos receptores. Estes canais são fechados após uma complexa série de processos 
Estudo computacional sobre a influência de sinapses elétricas entre bastonetes na faixa dinâmica escotópica da retina de vertebrados

envolvendo a ativação do pigmento rodopsina no caso dos bastonetes e redução na concentração de guanosina monofosfato (cGMP) no segmento externo do bastonete (PUGH \& LAMB, 2000).

Em uma primeira aproximação, os dois tipos de fotorreceptores podem ser encontrados em toda a extensão da retina, com uma única exceção conhecida na região central da fóvea que não possui bastonetes (RODIECK, 1988). No caso dos primatas, imediatamente fora da região central da fóvea, a densidade espacial das células cai com o aumento da excentricidade, com exceção dos bastonetes cujo pico de densidade ocorre por volta de $20^{\circ}$ de excentricidade.

$\mathrm{Na}$ retina de vertebrados, os fotorreceptores estão acoplados entre si por sinapses elétricas mediadas por junções gap conforme indicado por diversas evidências experimentais (RAVIOLA \& GILULA, 1973; TESSIER-LAVIGNE \& ATTWELL, 1988; DEANS et al., 2002; ZHANG \& WU, 2005). Resultados mais recentes mostram que a intensidade do acoplamento existente entre cones e bastonetes e entre dois bastonetes é bastante semelhante, com condutâncias na faixa de 200-500 pS para os dois casos (ZHANG \& WU, 2005). A presença das sinapses elétricas na camada receptora possibilita a existência de diversos circuitos alternativos ao circuito primário de processamento escotópico, em que os bastonetes enviam sinais diretamente para as células bipolares. O acoplamento elétrico é responsável pelo aumento na relação sinal/ruído em algumas circunstâncias (TESSIER-LAVIGNE \& ATTWELL, 1988) e neste trabalho sua importância na faixa dinâmica da retina será discutida.

\section{Camada nuclear interna}

A camada nuclear interna da retina de vertebrados é composta por três grandes grupos celulares: células horizontais, células bipolares e células amácrinas. As células horizontais são divididas em dois grupos (HI e HII) nos primatas e em algumas espécies de mamíferos, realizando contatos sinápticos exclusivamente na camada plexiforme externa, onde coletam sinais dos fotorreceptores realizando um feedback negativo e transmitindo esses sinais para as células bipolares (STERLING, 1998).

Um dos papeis das células horizontais é o de controlar o nível de ativação das células bipolares através deste mecanismo de feedback negativo com os cones, ou seja, em resposta ao sinal recebido desses receptores as células horizontais realizam uma 
conexão inibitória. Este mecanismo inibitório pode ser transmitido lateralmente através das sinapses elétricas presentes entre células horizontais (WEILER et al., 2000), garantindo que qualquer redundância do sistema seja eliminada e somente a diferença entre o sinal local e a média seja transmitida. Além disso, as células horizontais contribuem para a formação do campo receptivo das células bipolares e amácrinas do tipo ON/OFF participando do circuito OFF, ou seja, realizam conexões com as células bipolares e transmitem lateralmente os sinais quando o estímulo é retirado do centro do campo receptivo e aplicado em sua região periférica (DACEY, 1996). Alguns trabalhos mostram também que esse grupo celular está relacionado com o antagonismo a cores, realizando contatos sinápticos seletivos com um ou mais dos três tipos de cones (KAMERMANS \& SPEKREIJSE, 1995). Como a modelagem feita neste trabalho só inclui a presença dos circuitos mediados pelos bastonetes que respondem a regiões luminosas sobre um fundo escuro (circuito $\mathrm{ON}$ ) e não inclui visão colorida, as células horizontais e as células que só participam do circuito responsável pela resposta a regiões escuras sobre um fundo claro (circuito OFF) não foram modeladas.

As celulas bipolares são os neurônios que ocupam a região intermediária da camada nuclear interna, mantendo um potencial de repouso na faixa de -30 a $-40 \mathrm{mV}$ e respondendo ao estímulo luminoso com alterações graduais no potencial de membrana, sem apresentar potenciais de ação (KANEKO et al., 1989). As células bipolares podem ser classificadas de acordo com a resposta apresentada durante a apresentação do estímulo ou após seu término (ON e OFF) e de acordo com os contatos sinápticos que realizam. Enquanto a maioria das células bipolares apresenta uma separação nítida recebendo sinais de cones ou de bastonetes, algumas evidências mostram que um tipo de célula bipolar pode receber contado de ambos os receptores (TSUKAMOTO et al., 2001).

As células bipolares mediadas pelos bastonetes, que serão chamadas de células bipolares dos bastonetes, sempre respondem a presença de estímulo com uma despolarização gradual de membrana (tipo $\mathrm{ON}$ ) e realizam conexões com os bastonetes e células amácrinas do tipo AII (STERLING et al., 1988). Diferentemente das células bipolares dos bastonetes, que pertencem a uma única classe, as células bipolares mediadas pelos cones, que serão chamadas de células bipolares dos cones, podem apresentar mais de 10 tipos distintos de morfologia (RODIECK, 1998). Além disso, cada tipo de célula bipolar dos cones pode responder tanto com uma despolarização ou 
Estudo computacional sobre a influência de sinapses elétricas entre bastonetes na faixa dinâmica escotópica da retina de vertebrados

com uma hiperpolarização de membrana em resposta a um estímulo luminoso (tipos ON e OFF). Neste trabalho, tanto as células bipolares dos bastonetes como as células bipolares dos cones são modeladas e utilizadas na construção dos circuitos primários e secundários da visão escotópica.

As células amácrinas representam o grupo de neurônios da retina com maior variedade funcional e morfológica. Não se sabe ao certo quanto tipos de células amácrinas existem, mas o número pode variar na faixa de 20 a 40 tipos distintos (RODIECK, 1998). As células amácrinas do tipo ON-OFF podem ser encontradas nos circuitos da retina mediados por cones ou bastonetes, ou seja, elas podem participar tanto do processamento de sinais sob condições de alta quanto de baixa intensidade luminosa. A resposta gerada por esse tipo de célula é caracterizada por potenciais de ação dependentes da concentração do íon $\mathrm{Na}^{+}$(DACHEUX \& RAVIOLA, 1995), que podem ser ativados mediante a apresentação do estímulo ou assim que este é retirado. Outra característica importante é a liberação de neurotransmissores do tipo GABA (KANEKO, 1970), gerando uma inibição nas células das camadas posteriores e anteriores da retina, como células ganglionares e bipolares.

Apesar de alguns tipos de células amácrinas apresentarem potenciais de ação (ELIASOF et al., 1987; MILLER et al., 2006), as células amácrinas AII que participam dos circuitos mediados pelos bastonetes geralmente respondem ao estímulo luminoso com uma variação gradual no potencial de membrana, gerando potenciais de ação somente sob condições específicas (SMITH \& VARDI, 1995). Nos circuitos mediados pelos bastonetes, as células amácrinas AII realizam conexões excitatórias com as células bipolares dos cones de tipo ON (DEANS et al., 2002). A alta convergência existente entre as camadas de receptores e de células bipolares e as células amácrinas AII (tabela 17) pode contribuir para um aumento na relação sinal/ruído da rede para estímulos de alta intensidade, mas esta mesma convergência pode diminuir a relação sinal/ruído para estímulos menos intensos. Para evitar que isso ocorra, alguns mecanismos como o acoplamento por sinapses elétricas e a presença de canais dependentes do potencial de membrana contribuem para um aumento nessa relação (FAMIGLIETTI \& KOLB, 1975; VARDI \& SMITH, 1996). Um aumento na relação sinal/ruído pode ser resultante de uma melhor discriminação entre ruído e sinais de baixa intensidade, sendo relacionado neste caso com um aumento na faixa dinâmica da rede devido ao aumento da sensibilidade. Todos os mecanismos presentes nas células 
amácrinas AII responsáveis pelo aumento na relação sinal/ruído estão presentes no modelo de retina descrito nos próximos capítulos, de modo a garantir que a faixa dinâmica da rede seja a maior possível.

\section{Camada das células ganglionares}

A última camada nuclear da retina é composta por uma única classe de célula que representa a saída da rede, enviando os potenciais de ação através dos axônios do nervo óptico. Assim como as células amácrinas, bipolares e horizontais, as células ganglionares também são classificadas de acordo com sua morfologia e como respondem à apresentação e à retirada de um estímulo luminoso. $\mathrm{O}$ número exato de células ganglionares com diferentes morfologias encontradas na retina de vertebrados ainda não é conhecido, as evidências experimentais sugerem um número próximo de 20 (KOLB et al., 1981; KOLB et al., 1992).

Cada tipo de célula ganglionar contribui enviando sinais para um região específica do cérebro, controlando o movimento dos olhos e cabeça de acordo com o movimento da imagem. No gato, cerca de $60 \%$ das células ganglionares enviam suas saídas para o núcleo geniculado lateral, que redireciona esses sinais para um processamento no córtex estriado (STERLING, 1998). Os tipos alfa e beta de células ganglionares se diferenciam pela morfologia e resposta ao estímulo, direcionando suas saídas para o núcleo geniculado lateral (STEIN et al., 1996). As células do tipo alfa apresentam uma árvore dendrítica mais esparsa quando comparada com a das células do tipo beta, enquanto as células beta apresentam uma árvore dendrítica mais compacta e um disparo contínuo de potenciais de ação em resposta ao estímulo luminoso.

Os campos receptivos das células ganglionares são determinados por seu padrão de conexão e apresentam duas sub-regiões circulares e concêntricas com propriedades antagônicas. As células ganglionares do tipo $\mathrm{ON}$, quando submetidas a iluminação na região central do seu campo receptivo, apresentam aumento de sua atividade e quando submetidos a iluminação na periferia do seu campo receptivo apresentam diminuição ou supressão da atividade. As células ganglionares do tipo OFF, quando submetidas a iluminação na periferia do seu campo receptivo apresentam aumento de sua atividade e 
Estudo computacional sobre a influência de sinapses elétricas entre bastonetes na faixa dinâmica escotópica da retina de vertebrados

quando submetidas a iluminação na região central de seu campo receptivo apresentam diminuição ou supressão da atividade (STERLING, 1998 ; BEAR et al., 2002).

Para o modelo da retina construído neste trabalho, foi utilizado apenas um modelo de célula ganglionar, que recebe conexões das células bipolares dos cones ou dos bastonetes e é do tipo ON, ou seja, de todos os possíveis circuitos de processamento escotópico na retina apenas a via $\mathrm{ON}$ composta por células bipolares e ganglionares do tipo ON foi simulada.

\section{Circuitos primário e secundário}

A retina de vertebrados é uma estrutura bastante complexa, composta por uma grande variedade de neurônios diferenciados em relação a sua morfologia e função. Esses neurônios estão conectados em padrões complexos que variam em função da camada em que se encontram e das populações de células envolvidas. Ao longo do dia, a retina deve responder a estímulos cujas intensidades podem variar por um fator da ordem de $10^{10}$ (STERLING, 1998). Para isso, são necessários diferentes circuitos que operam sob diferentes condições de luminosidade. Durante a luz do dia os cones são ativados, transmitindo sinais para as células bipolares dos cones. Após a despolarização das células bipolares do tipo $\mathrm{ON}$, esse sinal é enviado diretamente para as células ganglionares através de uma conexão excitatória baseada em glutamato (SIKORA et al., 2005). Quando a intensidade luminosa cai, durante o período de lusco-fusco do início da noite, o circuito mediado pelos bastonetes é ativado (STERLING, 1998).

A existência de diferentes circuitos para a transmissão de sinais escotópicos (figura 6) é confirmada por diversos estudos fisiológicos e psicofísicos (BLOOMFIELD \& DACHEUX, 2001). O circuito primário dos bastonetes na retina de mamíferos tem início com os bastonetes se conectando com as células bipolares dos bastonetes através de uma sinapse excitatória especializada chamada de sinapse ribbon (SIKORA et al., 2005). As células bipolares do tipo ON despolarizam em resposta ao estímulo luminoso de forma gradual, codificando informação durante todo o intervalo de tempo em que o estímulo é apresentado. 
A

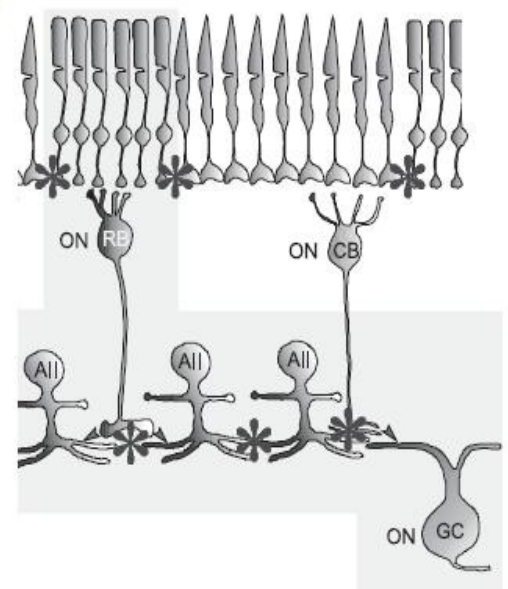

B

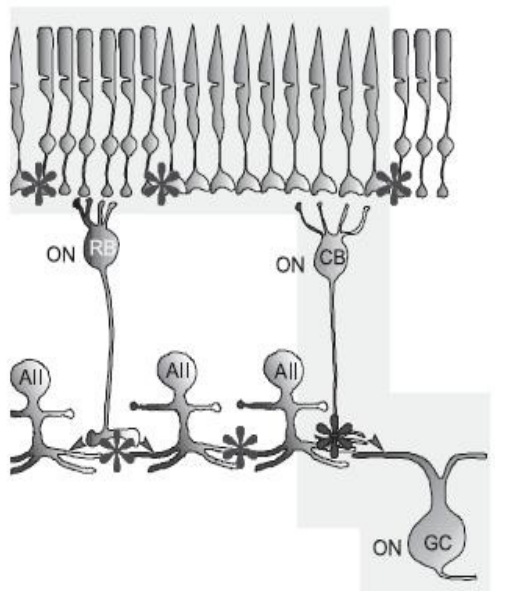

Figura 5. Circuitos primário e secundário mediados pelos bastonetes na retina de mamíferos. As sinapses elétricas estão representadas por estrelas. A. no circuito primário os bastonetes enviam sinais para as células bipolares dos bastonetes (RB) e em seguida para as células amácrinas do tipo AII (AII). As células amácrinas realizam sinapses elétricas entre si e com as células bipolares dos cones (CB), que transmitem os sinais para as células ganglionares (GC) através de uma sinapse química excitatória. B. no circuito secundário os sinais recebidos pelos bastonetes são transmitidos para os cones através das sinapses elétricas existentes entre os bastonete e os cones. Em seguida, os cones enviam os sinais para as células bipolares dos cones que realizam contatos sinápticos diretos com as células ganglionares. Figura adaptada de VOLGYI et al., 2004.

Quando as células bipolares despolarizam, as células amácrinas AII também despolarizam devido a presença de uma sinapse excitatória entre as duas células. A despolarização das células amácrinas é transmitida para as células bipolares dos cones através das sinapses elétricas existentes nessa camada (VARDI \& SMITH, 1996; DEANS et al., 2002; VOLGYI et al., 2004). Neste ponto, o sinal vindo do circuito primário mencionado anteriormente é somado ao sinal vindo do circuito secundário (Figura 5). A contribuição do circuito secundário se inicia na camada de receptores, com os cones sendo hiperpolarizados pelos sinais recebidos através das sinapses elétricas com os bastonetes. Após a hiperpolarização dos cones, estes enviam sinais para as células bipolares dos cones através de sinapses do tipo ribbon (SIKORA et al., 2005). Os sinais de ambos os circuitos convergem para as células bipolares dos cones do tipo $\mathrm{ON}$, que respondem com uma despolarização gradual de membrana ativando as células ganglionares do tipo ON-beta, que disparam potenciais de ação.

Neste trabalho, a contribuição de cada um dos circuitos descritos acima sobre a faixa dinâmica da retina é explorada através do bloqueio total ou parcial das sinapses elétricas presentes na camada receptora e na camada plexiforme interna. 
Estudo computacional sobre a influência de sinapses elétricas entre bastonetes na faixa dinâmica escotópica da retina de vertebrados

\section{Capítulo III}

\section{Modelo da Retina}

O processo de construção do modelo da retina foi realizado em diversas etapas até a obtenção de um modelo biologicamente plausível, ou seja, que possuísse características biológicas semelhantes àquelas observadas na retina de vertebrados. A etapa inicial correspondeu ao levantamento de dados experimentais utilizados na construção do modelo, como propriedades passivas e ativas de membrana de cada neurônio, além dos dados relativos ao padrão de conexão entre as células de uma mesma camada e de camadas diferentes.

As propriedades passivas se referem à morfologia do neurônio e a algumas propriedades independentes dos canais iônicos presentes na célula, como a resistência específica de membrana, a capacitância específica de membrana e a resistência axial. As propriedades ativas correspondem aos mecanismos cujo comportamento é variável, seja em função do tempo, do potencial de membrana, da concentração de um determinado íon ou de outra grandeza qualquer. Dentre as propriedades ativas de um neurônio estão a condutância e o potencial de reversão relativos a um determinado íon.

Para a construção de estruturas biologicamente plausíveis é necessário que se disponha de dados experimentais sobre os neurônios individuais e sobre os critérios de conectividade a ser utilizados na rede. Além disso, é necessário adotar um fator de escala para a redução do modelo já que o número de células na retina é muito superior ao número de células que poderiam ser modeladas de forma biologicamente plausível.

Neste capítulo é feita uma descrição completa de todas as propriedades ativas e passivas dos neurônios utilizados no modelo, bem como dos padrões de conexões e sinapses presentes em cada etapa da estrutura laminar da retina. As equações e parâmetros obtidos através dos dados experimentais disponíveis vêm de diversas espécies. Neste trabalho os dados utilizados foram obtidos de trabalhos realizados em larvas de salamandra tigre (Ambystoma tigrinum), gatos, e camundongos (BAYLOR et al., 1984; BARNES \& HILLE, 1989; KANEKO et al., 1989; VARDI \& SMITH, 1996; FOHLMEISTER \& MILLER, 1997). 
Muitos modelos compartimentais de neurônios são desenvolvidos a partir da reconstrução morfológica completa dos neurônios originais, dando origem a modelos com centenas de compartimentos elétricos representando o corpo celular e a árvore dendrítica (SHEASBY \& FOHLMEISTER, 1999). Os canais iônicos e outros mecanismos ativos presentes nos neurônios são distribuídos ao longo desses compartimentos de acordo com os dados experimentais. Cada compartimento possui duas resistências (axial e de membrana) e uma capacitância além dos canais iônicos dependentes do potencial de membrana ou da concentração de um íon. Um determinado grupo de compartimentos é simulado como como uma série de cabos cilíndricos acoplados, o que permite considerar a atenuação espacial e a temporal decorrentes da condução dos sinais através da membrana e ao longo de dendritos ou axônios (RALL, 1967; RALL et al., 1992; SEGEV, 1995; KOCH, 1999). Apesar desses modelos apresentarem resultados semelhantes aos obtidos experimentalmente, para este trabalho uma abordagem diferente foi utilizada.

Para todos os neurônios da rede, foram utilizados modelos de um único compartimento elétrico com uma densidade uniforme para um mesmo tipo de canal iônico. Ao utilizar esta abordagem, viabilizou-se a construção de uma rede em larga escala visando o estudo de mecanismos como sinapses elétricas, porém, em contrapartida, abriu-se mão do estudo da influência de fenômenos relacionados à morfologia da célula, como o processamento dendrítico. O balanço entre custo computacional e nível de realismo do modelo gera um debate até os dias atuais entre os cientistas e é feito de acordo com o objetivo de cada trabalho.

\section{Fotocorrente}

Apesar deste modelo se concentrar na visão mediada por bastonetes, é necessário modelar também os cones já que estes participam dos circuitos que operam em condições de baixa luminosidade, recebendo sinais dos bastonetes através de sinapses elétricas (VOLGYI et al., 2004). Todos os receptores utilizam o mesmo mecanismo mencionado no capítulo anterior para a conversão dos fótons absorvidos em sinais elétricos que serão transmitidos para outras células, respondendo com uma intensidade dependente do número de fótons capturados. Ao invés de simular todo o processo de transdução que ocorre nos segmentos externos do receptores, apenas a corrente gerada 
Estudo computacional sobre a influência de sinapses elétricas entre bastonetes na faixa dinâmica escotópica da retina de vertebrados

pela absorção de um fóton foi simulada. Essa fotocorrente foi modelada por uma equação ajustada para reproduzir as respostas experimentais (BAYLOR et al., 1984), representando o comportamento observado in vitro.

Antes da absorção do fóton pelo receptor, existe um fluxo de cargas constante formado por íons de cálcio e sódio entrando no segmento externo do receptor. Da mesma forma, existe um fluxo de íons de potássio entrando no segmento interno. $\mathrm{O}$ equilíbrio entre esses dois fluxos é chamado de corrente de escuro. Após a ativação das moléculas do pigmento visual há um fechamento dos canais seletivos a cálcio e sódio, enquanto o movimento de íons de potássio para o segmento interno continua. Quando um fóton atinge os discos membranosos do bastonete, a corrente de escuro que possui um fluxo constante entre os segmentos internos e externos é gradativamente bloqueada. A alteração na corrente de escuro causada pela absorção de um ou mais fótons é chamada de fotocorrente.

Um modelo realista para o processo de fototransdução (KAMIYAMA et al., 1996) que dá origem à fotocorrente teria como conseqüência um custo computacional inviável para os objetivos deste trabalho, dada a quantidade de células receptoras utilizadas no modelo. Sendo assim, uma abordagem computacionalmente mais barata foi adotada. A forma da fotocorrente foi reproduzida através de um ajuste dos parâmetros da equação 13 até que se produzisse uma resposta semelhante à observada em trabalhos experimentais e teóricos (BAYLOR et al., 1984 ; RISPOLI, 1998; LIU \& KOURENNYI., 2004). Desta forma, tem-se:

$$
I(t)=I_{\text {escuro }}(t)+A\left[\left(1-\mathrm{e}^{-t / \tau_{1}}\right)-\left(\frac{1}{1+\mathrm{e}^{-t+b / \tau_{2}}}\right)+\left(1-\mathrm{e}^{-t / \tau_{3}}\right)\right]
$$

onde $I_{\text {escuro }}$ representa a corrente na ausência de estímulos luminosos (corrente de escuro) e o segundo termo é chamado de fotocorrente (BAYLOR et al., 1984 ; LIU \& KOURENNYI., 2004). $A$ é a amplitude da fotocorrente e $\tau_{1}, \tau_{2}, \tau_{3}$ e $b$ são constantes de tempo em ms. As constantes utilizadas para este modelo são dadas por: $I_{\text {escuro }}=-0.04$ $\mathrm{nA}, \tau_{1}=50 \mathrm{~ms}, \tau_{2}=450 \mathrm{~ms}, \tau_{3}=800 \mathrm{~ms}$ e $b=3800 \mathrm{~ms}$. A amplitude da fotocorrente está representada na figura 6 . 


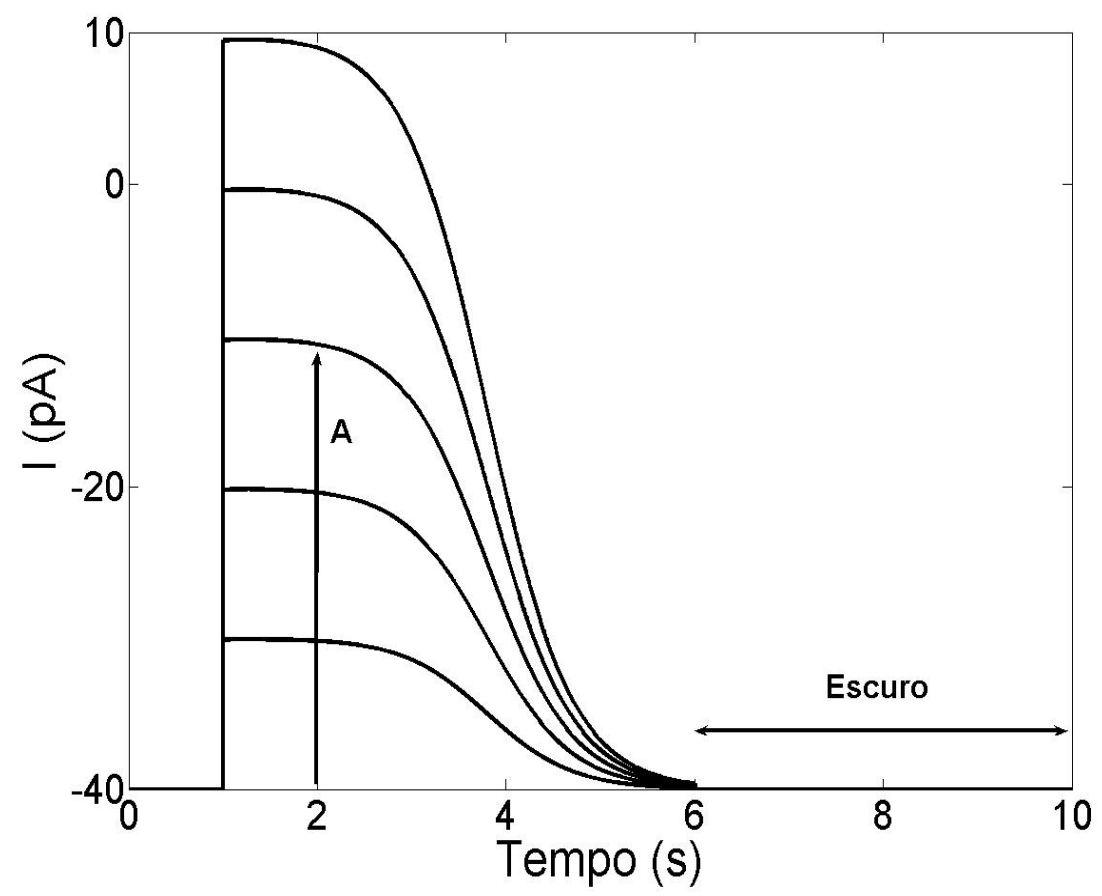

Figura 6. Relação entre o estímulo luminoso e a corrente que flui entre os compartimentos do bastonete. Na ausência de estímulo existe a corrente de escuro representada por Escuro na figura, cujo valor é de $40 \mathrm{pA}$. Na presença do estímulo luminoso, a corrente é parcialmente bloqueada, dando origem a uma corrente de nova amplitude (representada na figura por A). A figura mostra a resposta da fotocorrente a uma série de estímulos de intensidades crescentes.

Para todos os bastonetes a fotocorrente é injetada no compartimento, simulando a alteração na corrente de escuro provocada pelo processo de transdução luminosa. Por participar do circuito mediado pelos bastonetes apenas passivamente, recebendo estímulos destes através de sinapses elétricas (DEANS et al., 2002 ; VOLGYI et al., 2004), os cones não recebem nenhuma injeção de fotocorrente, apesar do processo de transdução ser semelhante nos dois receptores.

\section{Bastonetes}

O modelo de bastonete consiste de um único compartimento elétrico com propriedades passivas como resistência de membrana, resistência axial do citoplasma e capacitância de membrana, além de quatro canais iônicos dependentes do potencial de membrana e dois canais dependentes da concentração de cálcio. Os segmentos interno e externo do bastonete presentes nos vertebrados foram colapsados neste modelo dando origem a um único compartimento. Os resultados iniciais mostraram que não existe 
Estudo computacional sobre a influência de sinapses elétricas entre bastonetes na faixa dinâmica escotópica da retina de vertebrados

diferença significativa entre um modelo com dois compartimentos e um com um único compartimento colapsado (PUBLIO et al., 2006).

Todos os canais iônicos presentes no compartimento foram modelados de acordo com o formalismo de Hodgkin-Huxley, conforme a descrição no capítulo 2. Os parâmetros para cada canal são dados nas tabelas 1 e 3 enquanto que as equações referentes às taxas de variação e correntes iônicas são descritas na tabela 2. As equações relativas às variáveis de ativação e inativação são descritas no capítulo 1 pelas equações 6,7 e 8. Desta forma, serão apresentadas nas tabelas abaixo apenas as taxas $\alpha(V)$ e $\beta(V)$ necessárias para o cálculo das variáveis de ativação e inativação, obtidas a partir de trabalhos experimentais.

Tabela 1. Parâmetros passivos utilizados na construção do modelo do bastonete. A última coluna da tabela contém as referências de onde foram retirados os valores.

\begin{tabular}{l|r|l}
\hline Grandeza. & Valor. & Referência. \\
\hline Capacitância de membrana $(C)$. & $20 \mathrm{pF}$. & (OGURA et al., 2003) \\
\hline Potencial de repouso $\left(V_{\text {rep }}\right)$. & $-38 \mathrm{mV}$ & (BAYLOR et al., 1984) \\
\hline Diâmetro do compartimento. & $8 \mu \mathrm{m}$ & (STERLING, 1998) \\
\hline Comprimento do compartimento. & $8 \mu \mathrm{m}$ & (STERLING, 1998 \\
\hline
\end{tabular}

Os canais de potássio $K_{x}$ participam no estabelecimento do potencial de repouso do bastonete na ausência de estímulo luminoso além de acelerar a resposta da célula em resposta aos estímulos luminosos (BEECH \& BARNES, 1989; KOURENNYI et al., 2004).

Algumas evidências experimentais (MARICQ \& KORENBROT, 1990) mostram que o segmento interno dos fotorreceptores de vertebrados possuem uma corrente dependente do potencial com características retificadoras $\left(K_{v}\right)$. Apesar de alguns trabalhos mostrarem que podem existir mais de um tipo de corrente retificadora de potássio em um mesmo segmento, é possível ajustar grande parte dos dados com um único modelo de corrente (KAMIYAMA et al., 1996).

O último canal seletivo a íons de potássio no modelo do bastonete é o canal de potássio dependente do potencial de membrana e da concentração de cálcio $\left(K_{C a}\right)$. Esta corrente é ativada com a despolarização de membrana e atinge sua amplitude máxima quando o potencial de membrana tem valor por volta de $20 \mathrm{mV}$ (BARNES \& HILLE, 1989). 
Tabela 2. Equações para as taxas de variação e correntes iônicas utilizadas no modelo. A última coluna da tabela contém as referências de onde as equações foram retiradas ou adaptadas.

\begin{tabular}{|c|c|c|}
\hline Corrente Iônica. & Taxas $\alpha(\mathrm{V})$ e $\beta(\mathrm{V})$. & Referência. \\
\hline$I_{K x}=G_{K x} n\left(V-E_{K}\right)$ & $\alpha_{K x}=\alpha_{0} e^{\left(V-V_{0.5}\right) / 2 \mathrm{~S}} ; \beta_{K x}=\beta_{0} e^{-\left(V-V_{0.5}\right) / 2 \mathrm{~S}}$ & $\begin{array}{l}\text { (KOURENNYI et al., } \\
\text { 2002) }\end{array}$ \\
\hline$I_{K v}=G_{K v} n^{4}\left(V-E_{K}\right)$ & $\alpha_{K x}=a \frac{20-V}{e^{(20-V) / 22}-1} ; \beta_{K x}=b e^{-(V / 80)}$ & $\begin{array}{l}\text { (LIU \& } \\
\text { KOURENNYI., 2004) }\end{array}$ \\
\hline$I_{K C a}=G_{K C a} m\left(V-E_{K}\right)$ & $m=\frac{[C a]_{i}}{[C a]_{i}+12}$ & (OGURA et al., 2003) \\
\hline$I_{h}=G_{h}\left(1-(1+3 n)(1-n)^{3}\right)\left(V-E_{h}\right)$ & $\alpha_{h}=\frac{a}{1+e^{(V+98) / 10}} ; \beta_{h}=\frac{b}{1+e^{-(V+30) / 20}}$ & $\begin{array}{l}\text { (BARNES \& HILLE, } \\
\text { 1989;MAO et al., } \\
\text { 2003) }\end{array}$ \\
\hline$I_{C a}=G_{C a} m^{4}\left(V-E_{C a}\right)$ & $\alpha_{C a}=\frac{300(30-V)}{e^{(30-V) / 15}-1} ; \beta_{C a}=\frac{1000}{e^{(V+30) / 12.7}+1}$ & (OGURA et al., 2003) \\
\hline$I_{C l(C a)}=G_{C l(C a)} m\left(V-E_{C l}\right)$ & $m=\frac{[\mathrm{Ca}]_{i}}{[\mathrm{Ca}]_{i}+10}$ & (OGURA et al., 2003) \\
\hline
\end{tabular}

Diversos trabalho experimentais confirmam a presença de uma corrente ativada pela hiperpolarização de membrana nos bastonetes, geralmente denominada $I_{h}$ (BAYLOR et al., 1984 ; MAO et al., 2003). Essa corrente é composta de diversos íons que entram na célula e é produzida a partir de estímulos que hiperpolarizam a membrana. Além disso, essa corrente possui um papel importante na formação do transiente inicial da resposta do bastonete (KAMIYAMA et al., 1996). Devido à importância dessa corrente na resposta dos bastonetes, seu papel na faixa dinâmica da rede será investigado detalhadamente nos próximos capítulos.

Os fotorreceptores de vertebrados expressam uma corrente de cálcio $I_{C a}$ que entra em seus terminais através de canais de cálcio do tipo $L$ (longa duração) que permite uma liberação contínua do neurotransmissor glutamato na ausência de estímulos luminosos e uma redução gradual da liberação desse transmissor de acordo com o aumento na intensidade do estímulo luminoso (BEECH \& BARNES, 1989; LIU \& KOURENNYI., 2004). Essa corrente de cálcio é um dos mecanismos responsáveis pela alteração na concentração intracelular de cálcio, que interfere diretamente nas variáveis de ativação e inativação dos canais de potássio dependente de cálcio $\left(I_{K C a}\right)$ e de cloreto dependente de cálcio $\left(I_{C l C a}\right)$, que é ativado com a despolarização de membrana (KAMIYAMA et al., 1996; OGURA et al., 2003). 
Estudo computacional sobre a influência de sinapses elétricas entre bastonetes na faixa dinâmica escotópica da retina de vertebrados

Tabela 3. Parâmetros utilizados no modelo do bastonete para as taxas de variação, condutâncias máximas e correntes iônicas. A última coluna da tabela contém as referências de onde os parâmetros foram retirados ou adaptados.

\begin{tabular}{|c|c|c|}
\hline Corrente Iônica. & Parâmetros. & Referência. \\
\hline$I_{K x}$ & $\begin{array}{c}\alpha_{0}=\beta_{0}=0.6 \mathrm{~ms}^{-1} ; V_{0.5}=-50 \mathrm{mV} ; S=5.4 \mathrm{mV} \\
G_{K x}=0.85 \mathrm{nS} ; E_{K}=-80 \mathrm{mV}\end{array}$ & $\begin{array}{l}\text { (KOURENNYI et al., } \\
\text { 2002) }\end{array}$ \\
\hline$I_{K v}$ & $\begin{array}{c}a=0.005 \mathrm{~ms}^{-1} ; b=0.0625 \mathrm{~ms}^{-1} \\
G_{K v}=10 \mathrm{nS} ; E_{K}=-80 \mathrm{mV}\end{array}$ & $\begin{array}{l}\text { (LIU \& } \\
\text { KOURENNYI., 2004) }\end{array}$ \\
\hline$I_{K C a}$ & $G_{K C a}=5 \mathrm{nS} ; E_{K}=-80 \mathrm{mV}$ & $\begin{array}{l}\text { (LIU \& } \\
\text { KOURENNYI., 2004) }\end{array}$ \\
\hline$I_{\mathrm{Cl}(\mathrm{Ca})}$ & $G_{C l(C a)}=1.3 n S ; E_{C l}=-20 m V$ & $\begin{array}{l}\text { (LIU \& } \\
\text { KOURENNYI., 2004) }\end{array}$ \\
\hline$I_{\mathrm{Ca}}$ & $G_{C a}=1 n S$ & $\begin{array}{l}\text { (KOURENNYI et al., } \\
\text { 2004) }\end{array}$ \\
\hline$I_{h}$ & $\begin{array}{c}a=b=0.03 \mathrm{~ms}^{-1} \\
G_{h}=0.3 \mathrm{nS} ; E_{h}=-32 \mathrm{mV}\end{array}$ & $\begin{array}{l}\text { (KAMIYAMA et al., } \\
\text { 1996; MAO et al., } \\
\text { 2003) }\end{array}$ \\
\hline
\end{tabular}

A entrada de $\mathrm{Ca}^{2+}$ se dá através da corrente $I_{C a}$ enquanto a saída do íon é feita por um mecanismo ativo de bombeamento (DESTEXHE et al., 1994). O influxo de cálcio em uma região logo abaixo da membrana é descrito por:

$$
\frac{d[C a]_{i}}{d t}=\frac{-k}{2 \cdot \text { F.d }} I_{C a}
$$

onde k é uma constante adimensional igual a 0.1, F é a constante de Faraday e d é a profundidade na qual ocorre o influxo, neste caso $d=1 \mu \mathrm{m}$. A contribuição da bomba na alteração da concentração interna do íon pode ser dada por:

$$
\frac{d[\mathrm{Ca}]_{i}}{d t}=\frac{-K_{T}[\mathrm{Ca}]_{i}}{[\mathrm{Ca}]_{i}+K_{d}}
$$

onde $K_{T}=10^{-4} \mathrm{mM} / \mathrm{ms}^{-1}$ e $K_{d}=10^{-4} \mathrm{mM}$ são as taxas de remoção. Finalmente, o potencial de reversão é descrito pela equação de Nerst:

$$
E_{C a}=k \frac{R T}{2 \mathrm{~F}} \log \frac{[\mathrm{Ca}]_{e}}{[\mathrm{Ca}]_{i}}
$$


onde $k$ é uma constante adimensional igual a $1000, R=8.3144 \mathrm{~J} \cdot \mathrm{mol}^{-1} \cdot \mathrm{K}^{-1}$, $T=309,15 \mathrm{~K}$ e $[\mathrm{Ca}]_{\mathrm{e}}=5.10^{-5} \mathrm{mM}$ e $[\mathrm{Ca}]_{\mathrm{i}}$ representam as concentrações externas e internas de cálcio respectivamente. Esse mecanismo ativo utilizado no modelo de bastonete é utilizado também nos demais modelos compartimentais descritos neste capítulo que possuem correntes iônicas dependentes da concentração interna de cálcio.

O modelo responde a uma série de fotocorrentes de diferentes amplitudes com um comportamento bastante semelhante ao observado experimentalmente em diversos trabalhos, apresentando um pico de resposta inicial seguido de uma resposta constante abaixo do potencial de repouso (BAYLOR et al., 1984 ; SCHNEEWEIS \& SCHNAPF, 1999; LIU \& KOURENNYI., 2004). Ao final do estímulo o potencial de membrana do bastonete volta para um valor similar ao inicial, próximo a $-40 \mathrm{mV}$ conforme mostra a figura 7.

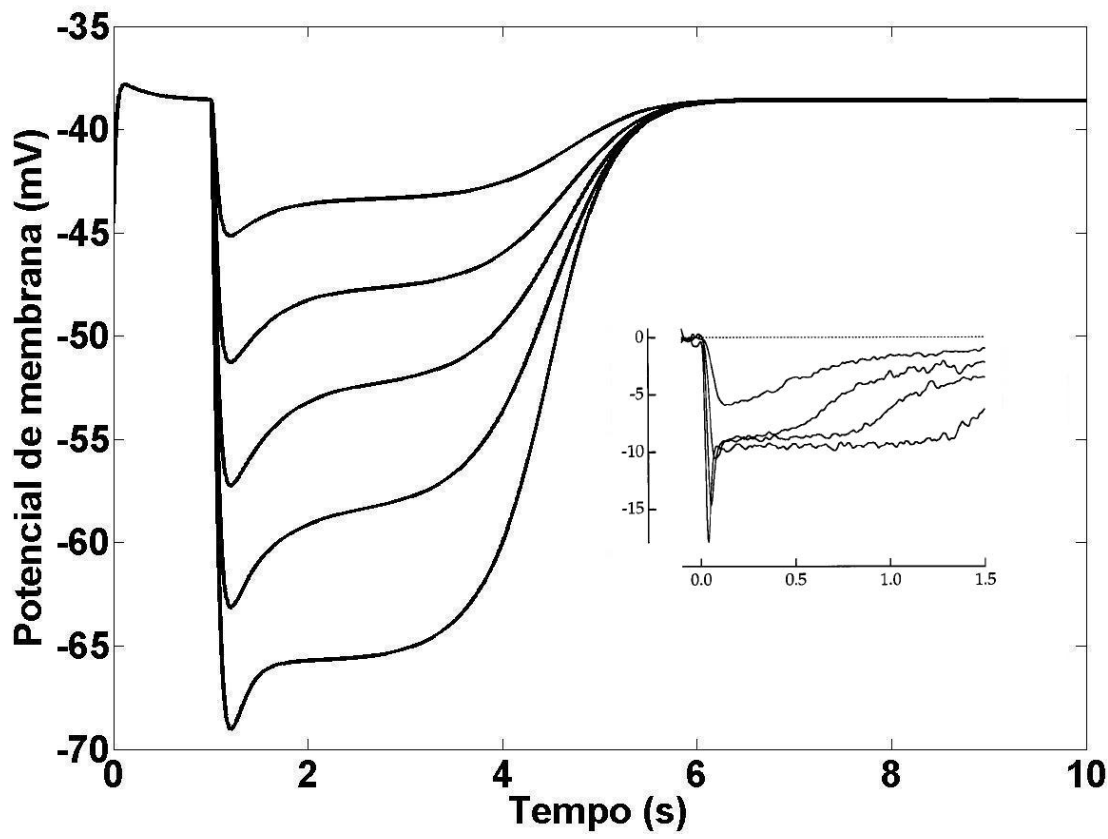

Figura 7. Respostas simuladas à fotocorrente. O gráfico mostra o potencial de membrana do bastonete em resposta ao estímulo para uma série de fotocorrentes (dadas na figura 6) de amplitude variando de $10 \mathrm{pA}$ a $50 \mathrm{pA}$ em passos de $10 \mathrm{pA}$ e duração $6 \mathrm{~s}$. A inserção à direita do gráfico representa a resposta experimental obtida para uma série de estímulos de amplitude crescente de 38 fótons $/ \mu^{2}$ a 2301 fótons $/ \mu^{2}$. Resposta experimental retirada de SCHNEEWEIS \& SCHNAPF, 1999. 
Estudo computacional sobre a influência de sinapses elétricas entre bastonetes na faixa dinâmica escotópica da retina de vertebrados

Apesar de existir uma boa concordância entre as respostas teórica e experimental para estímulos de maiores intensidades, o modelo não é capaz de reproduzir com fidelidade a resposta a estímulos de intensidades próximas a $1 \mathrm{pA}$, equivalentes à amplitude da fotocorrente produzida em resposta a estímulos com intensidades inferiores a 1 fóton $/ \mu \mathrm{m}^{2}$ (BAYLOR et al., 1984). Esta discrepância para valores mais baixos está diretamente relacionada com o modelo utilizado para a fotocorrente, capaz apenas de simular a forma da fotocorrente para intensidades luminosas superiores a este valor. Como neste trabalho nenhum estímulo inferior a 10 pA é utilizado, o modelo descrito consegue reproduzir os resultados observados experimentalmente para os estímulos utilizados no modelo de retina.

\section{Cones}

Os cones foram simulados neste modelo devido às evidências experimentais disponíveis que mostram a presença de sinapses elétricas entre cones e bastonetes (DEANS et al., 2002; VOLGYI et al., 2004), fazendo com que os cones também participem dos circuitos de processamento de sinais escotópicos.

Tabela 4. Equações para as taxas de variação e correntes iônicas utilizadas no modelo de cone. A última coluna da tabela contém as referências de onde as equações foram retiradas ou adaptadas.

\begin{tabular}{c|c|c}
\hline Corrente Iônica. & \multicolumn{1}{c}{ Taxas $\alpha(\mathrm{V})$ e $\beta(\mathrm{V})}$. & \multicolumn{1}{c}{ Referência. } \\
\hline$I_{K v}=G_{K v} m^{3} h\left(V-E_{K}\right)$ & $\alpha_{m K v}=a \frac{V-100}{1-e^{-(V-100) / 42}} ; \beta_{m K v}=b e^{(20-V / 40)}$ & $\begin{array}{l}\text { (KAMIYAMA et al., } \\
1996)\end{array}$ \\
\hline$I_{K C a}=G_{K C a} m^{2} h\left(V-E_{K}\right)$ & $\alpha_{h K v}=c e^{-V / 22} ; \beta_{h K v}=\frac{d}{1+e^{(10-V) / 7}}$ & \\
$h=\frac{0.5 I_{C a}}{0.3+0.5 I_{C a}}$ & $\alpha_{m K C a}=a \frac{V-80}{1-e^{-(V-80) / 40} ; \beta_{m K C a}=b e^{(-V / 35)}}$ & $\begin{array}{l}\text { (KOURENNYI et al., } \\
\text { 2004) }\end{array}$ \\
\hline$I_{h}=G_{h}\left(1-(1+3 n)(1-n)^{3}\right)\left(V-E_{h}\right)$ & $\alpha_{h}=\frac{a}{1+e^{(V+88) / 12}} ; \beta_{h}=\frac{b}{1+e^{-(V+18) / 19}}$ & $\begin{array}{l}\text { (BARNES \& HILLE, } \\
1989)\end{array}$ \\
\hline$I_{C a}=G_{C a} n\left(V-E_{C a}\right)$ & $\alpha_{C a}=\alpha_{0} e^{\left(V-V_{0.5}\right) / 2 S} ; \beta_{C a}=\beta_{0} e^{-\left(V-V_{0.5}\right) / 2 S}$ & $\begin{array}{l}\text { (KOURENNYI et al., } \\
\text { 2004) }\end{array}$ \\
\hline
\end{tabular}




\begin{tabular}{c|c|c}
\hline Corrente Iônica. & Taxas $\alpha(\mathrm{V})$ e $\beta(\mathrm{V})$. & \multicolumn{1}{c}{ Referência. } \\
\hline$I_{C l(C a)}=G_{C l(C a)} m\left(V-E_{C l}\right)$ & & (KOURENNYI et al., \\
$m=\frac{1}{1+e^{\left(0.37-0.5 I_{C a}\right) / 0.09}}$ & - & \\
\hline
\end{tabular}

Da mesma forma que o modelo de bastonete, o modelo de cone foi construído com um único compartimento, mesmas propriedades passivas do bastonete (tabela 1) e mesmos canais iônicos (descritos na tabela 4). Para as simulações envolvendo o cone, foi utilizado um modelo já disponível na literatura (KOURENNYI et al., 2004) cujos parâmetros e equações foram retiradas ou adaptadas de outros modelos teóricos e trabalhos experimentais dados pelas referências indicadas nas tabelas 4 e 5 .

Como os cones no presente modelo não recebem estímulos luminosos diretamente, mas apenas estímulos dos bastonetes mediados por junções gap, não foi necessária a utilização de um modelo de fotocorrente específico para os cones como foi feito com os bastonetes (KOURENNYI et al., 2004).

Tabela 5. Parâmetros utilizados no modelo de cone para as taxas de variação e correntes iônicas. A última coluna da tabela contém as referências de onde os parâmetros foram retirados ou adaptados.

\begin{tabular}{|c|c|c|}
\hline Corrente Iônica. & Parâmetros. & Referência. \\
\hline$I_{K C a}$ & $\begin{array}{c}a=15 \mathrm{~ms}^{-1} ; b=20 \mathrm{~ms}^{-1} \\
G_{K(C a)}=0.5 \mathrm{nS} ; E_{K}=-80 \mathrm{mV}\end{array}$ & $\begin{array}{l}\text { (KOURENNYI et al., } \\
\text { 2004) }\end{array}$ \\
\hline$I_{K v}$ & $\begin{array}{c}a=5 \mathrm{~ms}^{-1} ; b=9 \mathrm{~ms}^{-1} \\
c=0.15 \mathrm{~ms}^{-1} ; d=0.4125 \mathrm{~ms}^{-1} \\
G_{C l(\mathrm{Ca})}=2 \mathrm{nS} ; E_{K}=-80 \mathrm{mV}\end{array}$ & $\begin{array}{l}\text { (KOURENNYI et al., } \\
\text { 2004) }\end{array}$ \\
\hline$I_{\mathrm{Ca}}$ & $\begin{array}{c}\alpha_{0}=\beta_{0}=3.1 \mathrm{~ms}^{-1} ; V_{0.5}=-16.6 \mathrm{mV} ; S=5.7 \mathrm{mV} \\
G_{C a}=4.92 \mathrm{nS}\end{array}$ & $\begin{array}{l}\text { (KOURENNYI et al., } \\
\text { 2004) }\end{array}$ \\
\hline$I_{C l(C a)}$ & $G_{C l(C a)}=6.5 \mathrm{nS} ; E_{C l}=-20 \mathrm{mV}$ & $\begin{array}{l}\text { (KOURENNYI et al., } \\
2004 \text { ) }\end{array}$ \\
\hline$I_{h}$ & $\begin{array}{c}a=18 \mathrm{~ms}^{-1} ; b=18 \mathrm{~ms}^{-1} \\
G_{h}=3.5 \mathrm{nS} ; E_{h}=-32 \mathrm{mV}\end{array}$ & $\begin{array}{l}\text { (KOURENNYI et al., } \\
\text { 2004) }\end{array}$ \\
\hline
\end{tabular}


Estudo computacional sobre a influência de sinapses elétricas entre bastonetes na faixa dinâmica escotópica da retina de vertebrados

\section{Células Bipolares}

As células bipolares participam do circuito mediado pelos bastonetes recebendo conexões de cones e bastonetes e os enviando para as células amácrinas e ganglionares. Apesar das células bipolares serem divididas morfologicamente em 3 compartimentos simples que podem ser descritos como dendritos, corpo celular e axônio, neste modelo foram considerados apenas os canais presentes no corpo celular, de maneira que foi simulado apenas um único compartimento que recebe conexões dos receptores e envia sinais para as células amácrinas e ganglionares.

Além da aproximação para um único compartimento, as células bipolares dos cones e bastonetes foram simuladas por um único modelo, com a mesma dinâmica e apenas com alguns parâmetros distintos. A presença e o bloqueio de uma corrente de potássio $\left(\mathrm{I}_{\mathrm{A}}\right)$ no modelo é suficiente para a reproduzir os comportamentos respectivos das células dos bastonetes e dos cones sem a necessidade de modelos distintos (USUI et al., 1996). Os parâmetros passivos utilizados na construção do modelo da célula bipolar estão dados na tabela 6 .

Tabela 6. Parâmetros passivos utilizados na construção do modelo da célula bipolar. A última coluna da tabela contém as referências de onde foram retirados os valores.

\begin{tabular}{l|r|l}
\hline Grandeza. & Valor. & Referência. \\
\hline Capacitância de membrana $(C)$. & $10 \mathrm{pF}$. & (MAO et al., 2003) \\
\hline Potencial de repouso $\left(V_{\text {rep }}\right)$. & $-38 \mathrm{mV}$ & $\begin{array}{l}(\text { KANEKO \& TACHIBANA, } \\
1985)\end{array}$ \\
\hline Diâmetro do compartimento. & $8 \mu \mathrm{m}$ & $\begin{array}{l}\text { (KANEKO \& TACHIBANA, } \\
1985)\end{array}$ \\
\hline Comprimento do compartimento. & $8 \mu \mathrm{m}$ & $\begin{array}{l}\text { (KANEKO \& TACHIBANA, } \\
1985\end{array}$ \\
\hline
\end{tabular}

Apesar de todos os fotorreceptores liberarem somente glutamato como transmissor, as células bipolares podem responder de forma diferente a esse transmissor, dependendo do tipo de receptor presente. Células do tipo ON sofrem despolarização na presença de estímulo (figura 8), enquanto as células do tipo OFF sofrem uma hiperpolarização na presença de estímulo. Para o modelo da rede, foi utilizado somente o modelo para a célula bipolar do tipo ON, por ser justamente a célula que participa do circuito mediado pelos bastonetes sob condições escotópicas (BERTSON et al., 2004). 
Os trabalhos experimentais realizados com as células bipolares identificam quatro componentes principais de correntes: corrente de cálcio $\left(I_{C a}\right)$, correntes de potássio dependentes do potencial de membrana com características retificadoras e dependentes da concentração interna de cálcio $\left(I_{K v}\right.$ e $\left.I_{K C a}\right)$, uma corrente ativada pela hiperpolarização de membrana $\left(I_{h}\right)$ e uma corrente constituída basicamente de íons de potássio que não sofre alteração após a utilização do bloqueador de potássio TEA $\left(I_{A}\right)$ (KANEKO \& TACHIBANA, 1985; USUI et al., 1996).
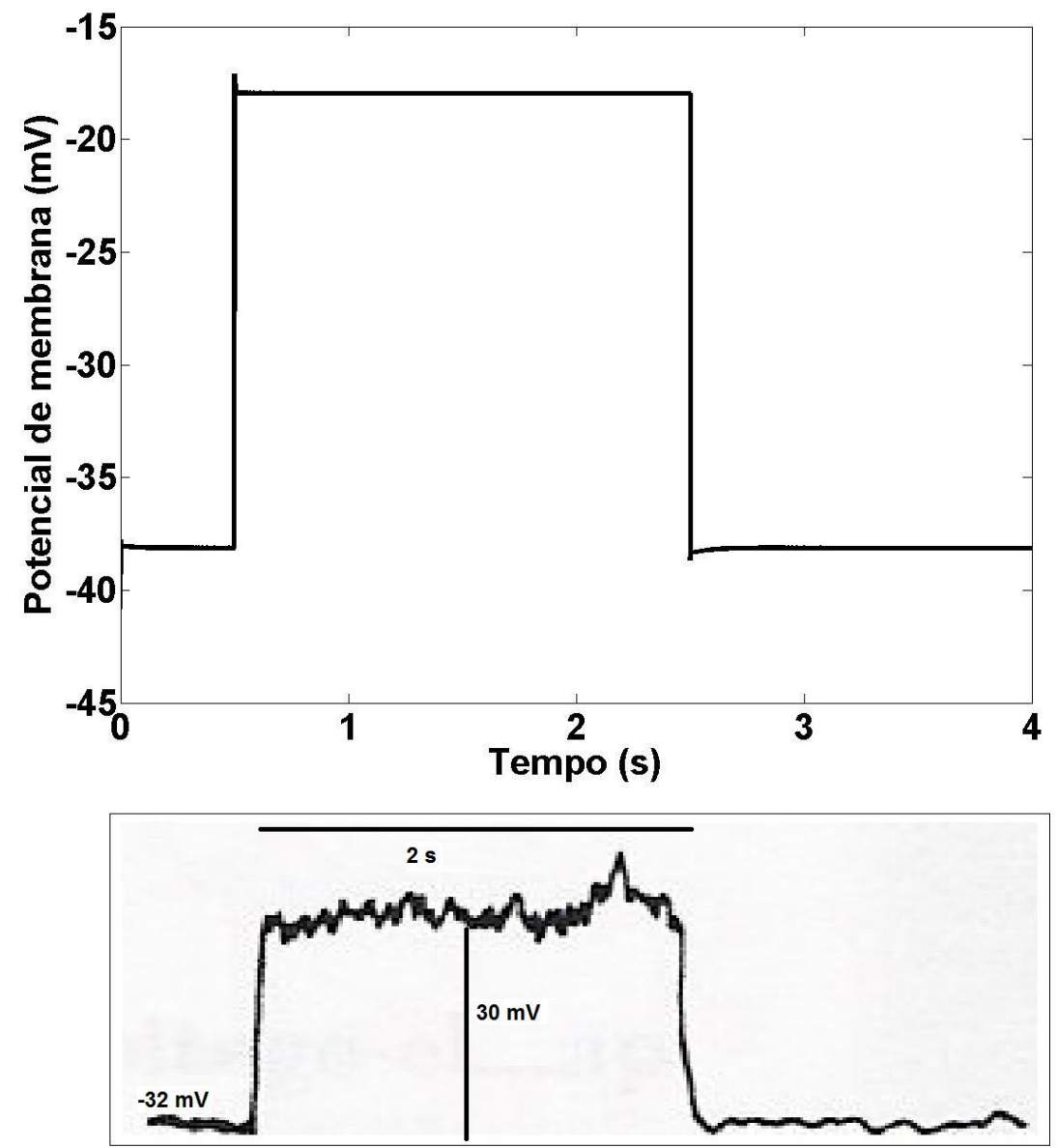

Figura 8. Respostas do modelo de célula bipolar a uma corrente injetada no compartimento. O gráfico mostra o potencial de membrana em resposta ao estímulo de amplitude de $20 \mathrm{pA}$ e duração $2 \mathrm{~s}$. A inserção abaixo do gráfico representa a resposta experimental obtida para um mesmo estímulo. Resposta experimental adaptada de KANEKO \& TACHIBANA, 1985.

Os resultados experimentais com injeção de corrente nas células bipolares (KANEKO \& TACHIBANA, 1985) mostram que o potencial de membrana mantém uma despolarização constante durante a aplicação do estímulo, principalmente devido a presença do canal de potássio dependente de cálcio. O potencial de membrana em 
Estudo computacional sobre a influência de sinapses elétricas entre bastonetes na faixa dinâmica escotópica da retina de vertebrados

resposta a uma corrente despolarizante de $2 \mathrm{pA}$, representado na figura 8 , mostra que o modelo é capaz de produzir um comportamento bastante semelhante ao observado experimentalmente, apresentando uma despolarização constante seguido de um rápido retorno ao potencial de repouso. Ao final do estímulo, o potencial de membrana da célula bipolar volta para um valor similar ao inicial, entre $-30 \mathrm{mV}$ e $-40 \mathrm{mV}$, conforme mostra a figura 8 .

Em resposta a uma corrente injetada no corpo celular, as células bipolares apresentam uma despolarização quase proporcional ao estímulo aplicado, com um potencial de repouso próximo a $-38 \mathrm{mV}$, conforme indicado na tabela 6 . Os demais parâmetros utilizados no modelo da célula bipolar estão indicados nas tabelas 7 e 8 .

Tabela 7. Equações para as taxas de variação e correntes iônicas utilizadas no modelo de célula bipolar. A última coluna da tabela contém as referências de onde as equações foram retiradas ou adaptadas.

\begin{tabular}{|c|c|c|}
\hline Corrente Iônica. & Taxas $\alpha(V)$ e $\beta(V)$ & Referência. \\
\hline$I_{K v}=G_{K v} m^{3} h\left(V-E_{K}\right)$ & $\begin{array}{c}\alpha_{m K v}=\frac{a}{e^{-(V-15) / 36}} ; \beta_{m K v}=b e^{(-V / 13)} \\
\alpha_{h K v}=c e^{-V / 7} ; \beta_{h K v}=\frac{d}{1+e^{-(V+115) / 15}}+0.02\end{array}$ & $\begin{array}{l}\text { (BARNES \& HILLE, } \\
\text { 1989;USUI et al., } \\
\text { 1996) }\end{array}$ \\
\hline $\begin{array}{c}I_{K C a}=G_{K C a} m_{1} m_{2}^{2}\left(V-E_{K}\right) \\
m_{1}=\frac{[C a]_{i}}{[C a]_{i}+0.3}\end{array}$ & $\alpha_{m K C a}=\frac{a(230-V)}{e^{(230-V) / 52}-1} ; \beta_{m K v}=b e^{(-V / 95)}$ & $\begin{array}{l}\text { (BARNES \& HILLE, } \\
\text { 1989; USUI et al., } \\
\text { 1996) }\end{array}$ \\
\hline$I_{h}=G_{h}\left(1-(1+3 n)(1-n)^{3}\right)\left(V-E_{h}\right)$ & $\alpha_{h}=\frac{a}{1+e^{(V+98) / 10}} ; \beta_{h}=\frac{b}{1+e^{-(V+30) / 20}}$ & $\begin{array}{l}\text { (BARNES \& HILLE, } \\
\text { 1989;MAO et al., } \\
\text { 2003) }\end{array}$ \\
\hline $\begin{array}{c}I_{C a}=G_{C a} m^{4} h\left(V-E_{C a}\right) \\
h=\frac{e^{-(V-50) / 11}}{e^{-(V-50) / 11}+1}\end{array}$ & $\alpha_{m C a}=\frac{a(120-V)}{e^{(V-120) / 25}-1} ; \beta_{m C a}=\frac{b}{e^{(V+68) / 25}+1}$ & $\begin{array}{l}\text { (BARNES \& HILLE, } \\
\text { 1989;USUI et al., } \\
\text { 1996) }\end{array}$ \\
\hline$I_{A}=G_{A} m^{3} h\left(V-E_{K}\right)$ & $\begin{array}{c}\alpha_{m A}=\frac{a}{e^{-(V-50) / 28}+1} ; \beta_{m A}=b e^{(-V / 10)} \\
\alpha_{h A}=c e^{-V / 13} ; \beta_{h A}=\frac{d}{1+e^{-(V-50) / 15}}\end{array}$ & $\begin{array}{l}\text { (BARNES \& HILLE, } \\
\text { 1989;USUI et al., } \\
\text { 1996) }\end{array}$ \\
\hline
\end{tabular}


Tabela 8. Parâmetros utilizados no modelo da célula bipolar para as taxas de variação, condutâncias máximas e correntes iônicas. A última coluna da tabela contém as referências de onde os parâmetros foram retirados ou adaptados.

\begin{tabular}{|c|c|c|}
\hline Corrente Iônica. & Parâmetros. & Referência. \\
\hline$I_{K v}$ & $\begin{array}{c}a=400 \mathrm{~ms}^{-1} ; b=1 \mathrm{~ms}^{-1} ; c=0.0003 \mathrm{~ms}^{-1} ; d=80 \mathrm{~ms}^{-1} \\
G_{K v}=2 n S ; E_{K}=-58 \mathrm{mV}\end{array}$ & (USUI et al., 1996) \\
\hline$I_{\mathrm{KCa}}$ & $\begin{array}{c}a=100 \mathrm{~ms}^{-1} ; b=120 \mathrm{~ms}^{-1} \\
G_{K C a}=8.5 \mathrm{nS} ; E_{K}=-58 \mathrm{mV}\end{array}$ & (USUI et al., 1996) \\
\hline$I_{A}$ & $\begin{array}{c}a=12000 \mathrm{~ms}^{-1} ; b=6 \mathrm{~ms}^{-1} ; c=0.45 \mathrm{~ms}^{-1} ; d=75 \mathrm{~ms}^{-1} \\
G_{A}=35 \mathrm{nS} ; E_{K}=-58 \mathrm{mV}\end{array}$ & (USUI et al., 1996) \\
\hline$I_{\mathrm{Ca}}$ & $\begin{array}{c}a=12000 \mathrm{~ms}^{-1} ; b=4000 \mathrm{~ms}^{-1} \\
G_{C a}=1.1 \mathrm{nS}\end{array}$ & (USUI et al., 1996) \\
\hline$I_{h}$ & $\begin{array}{c}a=b=0.3 \mathrm{~ms}^{-1} \\
G_{h}=2 n S ; E_{h}=-75 \mathrm{mV}\end{array}$ & $\begin{array}{l}\text { (KAMIYAMA et al., } \\
\text { 1996;MAO et al., } \\
\text { 2003) }\end{array}$ \\
\hline
\end{tabular}

\section{Células Amácrinas}

O terceiro neurônio do circuito mediato pelos bastonetes nos vertebrados é a célula amácrina do tipo AII, que na retina de gatos chega a receber sinais de aproximadamente 500 bastonetes (STERLING et al., 1988). Medidas experimentais mostram que a maioria das células amácrinas AII possuem canais de sódio e potássio dependentes do potencial de membrana e podem originar potenciais de ação em algumas circunstâncias in vitro (BOSS et al., 1993). Para o modelo de célula amácrina, foi utilizado um único compartimento com os canais de sódio e potássio observados experimentalmente, de forma semelhante a outros modelos disponíveis na literatura (BOSS et al., 1993 ; SMITH \& VARDI, 1995). Os parâmetros passivos utilizados no modelo compartimental da célula amácrina são dados na tabela 9. 
Estudo computacional sobre a influência de sinapses elétricas entre bastonetes na faixa dinâmica escotópica da retina de vertebrados

Tabela 9. Parâmetros passivos utilizados na construção do modelo da célula amácrina AII. A última coluna da tabela contém as referências de onde foram retirados os valores.

\begin{tabular}{l|r|l}
\hline Grandeza. & Valor. & Referência. \\
\hline Capacitância de membrana $(C)$. & $20 \mathrm{pF}$. & (ELIASOF et al., 1987) \\
\hline Potencial de repouso $\left(V_{\text {rep }}\right)$. & $-69 \mathrm{mV}$ & (SMITH \& VARDI, 1995) \\
\hline Diâmetro do compartimento. & $7 \mu \mathrm{m}$ & (SMITH \& VARDI, 1995 \\
\hline Comprimento do compartimento. & $7 \mu \mathrm{m}$ & (SMITH \& VARDI, 1995) \\
\hline
\end{tabular}

A corrente de sódio identificada experimentalmente na célula amácrina AII é ativada com uma despolarização de membrana por volta de $-30 \mathrm{mV}$ e atinge seu máximo em torno de $-10 \mathrm{mV}$, possuindo uma faixa bastante restrita de ativação de apenas $20 \mathrm{mV}$ (BOSS et al., 1993). A corrente de potássio utilizada no modelo é ativada com uma despolarização de membrana por volta de $-20 \mathrm{mV}$ e atinge seu máximo em torno de $+40 \mathrm{mV}$. Ambas as correntes foram modeladas com a mesma dinâmica dos canais de sódio e potássio utilizados no modelo de axônio de lula gigante (HODGKIN \& HUXLEY, 1952), enquanto os parâmetros utilizados em cada corrente foram ajustados de modo a produzir resultados semelhantes aos observados experimentalmente (BOSS et al., 1993). As equações e parâmetros utilizados no modelo compartimental da célula amácrina AII são descritos nas tabelas 10 e 11 .

Tabela 10. Equações para as taxas de variação e correntes iônicas utilizadas no modelo da célula amácrina AII. A última coluna da tabela contém as referências de onde as equações foram retiradas ou adaptadas.

\begin{tabular}{c|c|l}
\hline Corrente Iônica. & \multicolumn{1}{|c|}{ Taxas $\alpha(\mathrm{V})$ e $\beta(\mathrm{V})}$. & \multicolumn{1}{c}{ Referência. } \\
\hline$I_{N a}=G_{N a} m^{3} h\left(V-E_{N a}\right)$ & $\alpha_{m}=a \frac{25-V}{\left(e^{(25-V) / 10}-1\right)} ; \beta_{m K v}=b e^{(-V / 18)}$ & $\begin{array}{l}\text { (BOSS et al., 1993; } \\
\text { SMITH \& VARDI, } \\
1995)\end{array}$ \\
\hline$I_{K}=G_{K} n^{4}\left(V-E_{K}\right)$ & $\alpha_{h}=c e^{-V / 20} ; \beta_{h}=\frac{d}{1+e^{(30-V) / 10}}$ & $\begin{array}{l}\text { (BOSS et al., 1993; } \\
\text { SMITH \& VARDI, } \\
\text { 1995) }\end{array}$ \\
\hline
\end{tabular}

O modelo de célula amácrina foi construído com o objetivo de reproduzir a característica do potencial de membrana da célula em resposta ao glutamato liberado pelas célula bipolares, sem a necessidade de se modelar sua complexa árvore dendrítica. 
As células amácrinas AII apresentam uma despolarização de membrana semelhante a um potencial de ação único, seguido de uma manutenção da despolarização durante a aplicação do estímulo (ELIASOF et al., 1987 ; BOSS et al., 1993; SMITH \& VARDI, 1995). O modelo utilizado para a célula amácrina neste trabalho é o mesmo que o utilizado em outros modelos disponíveis na literatura (ELIASOF et al., 1987 ; SMITH \& VARDI, 1995), desta forma os parâmetros utilizados no modelo foram obtidos através do ajuste entre as curvas teóricas e experimentais para o potencial de membrana.

Tabela 11. Parâmetros utilizados modelo da célula amácrina AII para as taxas de variação, condutâncias máximas e correntes iônicas. A última coluna da tabela contém as referências de onde os parâmetros foram retirados ou adaptados.

\begin{tabular}{c|c|l}
\hline Corrente Iônica. & Parâmetros. & \multicolumn{1}{c}{ Referência. } \\
\hline$I_{N a}$ & $a=0.1 \mathrm{~ms}^{-1} ; b=4 \mathrm{~ms}^{-1} ; c=0.0014 \mathrm{~ms}^{-1} ; d=0.2 \mathrm{~ms}^{-1}$ & $\begin{array}{l}\text { (SMITH \& VARDI, } \\
1995)\end{array}$ \\
\hline$I_{K}$ & $G_{N a}=4 n S ; E_{K}=40 \mathrm{mV}$ & \\
\hline & $a=0.02 \mathrm{~ms}^{-1} ; b=0.025 \mathrm{~ms}^{-1}$ & $\begin{array}{l}\text { (SMITH \& VARDI, } \\
1995)\end{array}$ \\
\hline
\end{tabular}

\section{Células Ganglionares}

Estudos de grampeamento de potencial em células ganglionares da retina identificaram pelo menos cinco tipos diferentes de correntes iônicas responsáveis pela geração de potenciais de ação (LIPTON \& TAUCK, 1987 ; KANEDA \& KANEKO, 1991). Entre as correntes iônicas dependentes do potencial de membrana identificadas estão uma corrente de cálcio $\left(I_{C a}\right)$, correntes de potássio dependentes do potencial de membrana com características retificadoras e dependentes da concentração interna de cálcio $\left(I_{K v}\right.$ e $\left.I_{K C a}\right)$, uma corrente de sódio $\left(I_{N a}\right)$ e uma corrente constituída basicamente de íons de potássio que não sofre alteração após a utilização do bloqueador de potássio TEA $\left(I_{A}\right)$.

Para o modelo de célula ganglionar utilizou-se um modelo compartimental já disponível na literatura, construído a partir do ajuste dos parâmetros das equações com os dados experimentais e capaz de reproduzir a série de potenciais de ação gerados pelas células ganglionares quando a retina é submetida a estímulos luminosos 
Estudo computacional sobre a influência de sinapses elétricas entre bastonetes na faixa dinâmica escotópica da retina de vertebrados

(FOHLMEISTER \& MILLER, 1997). Esse modelo é capaz de responder em uma faixa larga de freqüências, com o número de disparos por segundo variando desde abaixo de 1 até acima de 100. A possibilidade da célula ganglionar responder nessa larga faixa permite explorar um grande conjunto de parâmetros da rede, analisando dessa forma os mecanismos que permitem aumentar a faixa dinâmica da retina. A tabela 12 indica as propriedades passivas do modelo compartimental da célula ganglionar.

Tabela 12. Parâmetros passivos utilizados na construção do modelo da célula ganglionar. A última coluna da tabela contém as referências de onde foram retirados os valores.

\begin{tabular}{l|r|l}
\hline Grandeza. & Valor. & Referência. \\
\hline Capacitância de membrana $(C)$. & $20 \mathrm{pF}$. & $\begin{array}{l}\text { (FOHLMEISTER \& } \\
\text { MILLER, 1997) }\end{array}$ \\
\hline Potencial de repouso $\left(V_{\text {rep }}\right)$. & $-65 \mathrm{mV}$ & $\begin{array}{l}\text { (FOHLMEISTER \& } \\
\text { MILLER, 1997) }\end{array}$ \\
\hline Diâmetro do compartimento. & $25 \mu \mathrm{m}$ & (STERLING, 1998) \\
\hline Comprimento do compartimento. & $25 \mu \mathrm{m}$ & (STERLING, 1998) \\
\hline
\end{tabular}

Ao contrário da corrente de sódio, a corrente de cálcio não possui variável de inativação (tabela 13). A redução da concentração de cálcio intracelular após um pico inicial ocorre exclusivamente devido ao fato de o potencial de reversão do cálcio ser dependente da concentração intracelular, conforme indicado anteriormente na equação 16. A alteração na concentração de cálcio intracelular na célula ganglionar é descrita pelo mesmo mecanismo utilizado nos bastonetes, sendo responsável pela regulação da corrente de potássio dependente de cálcio. As únicas diferenças entre os mecanismos de regulação da concentração interna de cálcio utilizados nos bastonetes e nas células ganglionares são os parâmetros $\mathrm{k}=3$ na equação $14 \mathrm{e}[\mathrm{Ca}]_{\mathrm{e}}=10^{-6} \mathrm{mM}$, ajustados para $\mathrm{o}$ modelo de célula ganglionar para reproduzir de maneira mais fiel os potenciais de ação observados experimentalmente (FOHLMEISTER \& MILLER, 1997). Os parâmetros utilizados para a modelagem das correntes iônicas presentes na célula ganglionar estão mostrados nas tabelas 13 e 14, assim como as referências de onde foram retirados. 
Tabela 13. Equações para as taxas de variação e correntes iônicas utilizadas no modelo de célula ganglionar. A última coluna da tabela contém as referências de onde as equações foram retiradas ou adaptadas.

\begin{tabular}{|c|c|c|}
\hline Corrente Iônica. & Taxas $\alpha(\mathrm{V})$ e $\beta(\mathrm{V})$ & Referência. \\
\hline$I_{K v}=G_{K v} n^{4}\left(V-E_{K}\right)$ & $\alpha_{n K v}=\frac{-a(V+40)}{e^{-(V+40) / 10}-1} ; \beta_{n K v}=b e^{-(V+50 / 80)}$ & $\begin{array}{l}\text { (FOHLMEISTER \& } \\
\text { MILLER, 1997) }\end{array}$ \\
\hline $\begin{array}{c}I_{K C a}=G_{K C a} m\left(V-E_{K}\right) \\
m=\frac{[C a]_{i}}{[C a]_{i}+1}\end{array}$ & -------" & $\begin{array}{l}\text { (FOHLMEISTER \& } \\
\text { MILLER, 1997) }\end{array}$ \\
\hline$I_{N a}=G_{N a} m^{3} h\left(V-E_{N a}\right)$ & $\begin{array}{c}\alpha_{m N a}=\frac{-a(V+30)}{e^{-(V+30) / 10}-1} ; \beta_{m N a}=b e^{-(V+55 / 18)} \\
\alpha_{h N a}=c e^{-(V+50) / 20} ; \beta_{h N a}=\frac{d}{1+e^{-(V+20)}}\end{array}$ & $\begin{array}{l}\text { (FOHLMEISTER \& } \\
\text { MILLER, 1997) }\end{array}$ \\
\hline$I_{C a}=G_{C a} c^{3}\left(V-E_{C a}\right)$ & $\alpha_{c C a}=\frac{-a(V+13)}{e^{-(V+13) / 10}-1} ; \beta_{c C a}=b e^{-(V+38) / 18}$ & $\begin{array}{l}\text { (FOHLMEISTER \& } \\
\text { MILLER, 1997) }\end{array}$ \\
\hline$I_{A}=G_{A} m^{3} h\left(V-E_{K}\right)$ & $\begin{array}{c}\alpha_{m A}=\frac{-a(V+90)}{e^{-(V+90) / 10}-1} ; \beta_{m A}=b e^{-(V+30 / 10)} \\
\alpha_{h A}=c e^{-(V+70) / 20} ; \beta_{h A}=\frac{d}{1+e^{-(V+40)}}\end{array}$ & $\begin{array}{l}\text { (FOHLMEISTER \& } \\
\text { MILLER, 1997) }\end{array}$ \\
\hline
\end{tabular}

A figura 9 mostra os potenciais de ação gerados pelo modelo compartimental da célula ganglionar em resposta a um estímulo de $10 \mathrm{pA}$, comparados com os resultados experimentais disponíveis na literatura (FOHLMEISTER \& MILLER, 1997). A inserção na figura 9 mostra os resultados experimentais para a aplicação de um estímulo de mesma intensidade. 
Estudo computacional sobre a influência de sinapses elétricas entre bastonetes na faixa dinâmica escotópica da retina de vertebrados

Tabela 14. Parâmetros utilizados no modelo da célula ganglionar para as taxas de variação, condutâncias máximas e correntes iônicas. A última coluna da tabela contém as referências de onde os parâmetros foram retirados ou adaptados.

\begin{tabular}{|c|c|c|}
\hline Corrente Iônica. & Parâmetros. & Referência. \\
\hline$I_{K v}$ & $\begin{array}{l}a=0.02 \mathrm{~ms}^{-1} ; b=0.4 \mathrm{~ms}^{-1} \\
G_{K v}=12 \mathrm{nS} ; E_{K}=-75 \mathrm{mV}\end{array}$ & $\begin{array}{l}\text { (FOHLMEISTER \& } \\
\text { MILLER, 1997) }\end{array}$ \\
\hline$I_{K C a}$ & $G_{K C a}=36 n S ; E_{K}=-75 \mathrm{mV}$ & $\begin{array}{l}\text { (FOHLMEISTER \& } \\
\text { MILLER, 1997) }\end{array}$ \\
\hline$I_{A}$ & $\begin{array}{c}a=0.006 \mathrm{~ms}^{-1} ; b=0.1 \mathrm{~ms}^{-1} ; c=0.04 \mathrm{~ms}^{-1} ; d=0.6 \mathrm{~ms}^{-1} \\
G_{A}=36 n S ; E_{K}=-75 \mathrm{mV}\end{array}$ & $\begin{array}{l}\text { (FOHLMEISTER \& } \\
\text { MILLER, 1997) }\end{array}$ \\
\hline$I_{\mathrm{Ca}}$ & $\begin{array}{c}a=0.3 \mathrm{~ms}^{-1} ; b=10 \mathrm{~ms}^{-1} \\
G_{C a}=2.2 \mathrm{nS}\end{array}$ & $\begin{array}{l}\text { (FOHLMEISTER \& } \\
\text { MILLER, 1997) }\end{array}$ \\
\hline$I_{N a}$ & $\begin{array}{c}a=0.6 \mathrm{~ms}^{-1} ; b=20 \mathrm{~ms}^{-1} ; c=0.4 \mathrm{~ms}^{-1} ; d=6 \mathrm{~ms}^{-1} \\
G_{\mathrm{Na}}=50 \mathrm{nS} ; E_{\mathrm{Na}}=35 \mathrm{mV}\end{array}$ & $\begin{array}{l}\text { (FOHLMEISTER \& } \\
\text { MILLER, 1997) }\end{array}$ \\
\hline
\end{tabular}

O modelo de célula ganglionar é capaz de reproduzir o seu comportamento de disparo de forma semelhante ao observado experimentalmente, porém existem algumas diferenças. Apesar de existir uma boa concordância entre as duas respostas, o modelo não é capaz de reproduzir o intervalo de tempo existente antes do primeiro potencial de ação, além de apresentar um diagrama de fase com forma um pouco diferente do observado experimentalmente (figuras 9 e 10). Essas discrepâncias entre os resultados experimentais e os obtidos com o modelo estão relacionadas com a limitação imposta pela configuração de um único compartimento (FOHLMEISTER \& MILLER, 1997).

Apesar de existirem modelos multi-compartimentais de células ganglionares na literatura (FOHLMEISTER \& SHEASBY, 1999), capazes de eliminar as discrepâncias observadas entre o modelo de um único compartimento e os dados experimentais, neste trabalho decidiu-se optar por um modelo de menor custo computacional. A utilização de modelos de neurônios com um único compartimento possibilita a construção de redes 
com um número maior de células ganglionares e a possibilidade de se investigar fenômenos coletivos, como sincronização de disparos na camada de saída da retina.
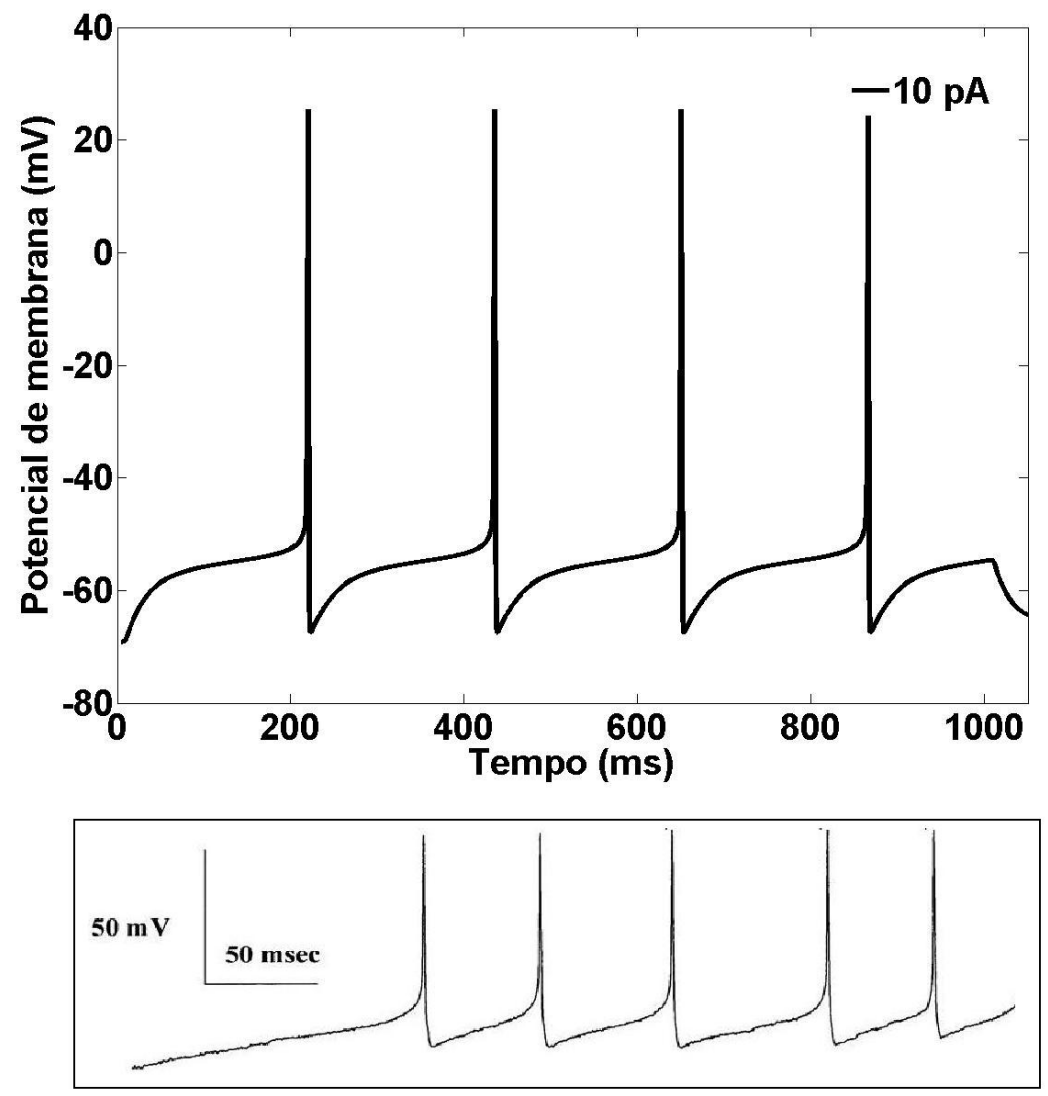

Figura 9. Potenciais de ação gerados pelo modelo compartimental da célula ganglionar para um estímulo de amplitude $10 \mathrm{pA}$ e duração de $1000 \mathrm{~ms}$. A inserção abaixo do gráfico representa a resposta obtida experimentalmente para a célula ganglionar a um estímulo de mesma amplitude. Resposta experimental retirada de FOHLMEISTER \& MILLER, 1997.

$\mathrm{Na}$ figura 10 estão representados os diagramas de fases do modelo de célula ganglionar para cinco valores de estímulo, indo de 10 pA a 50 pA em passos de 10 pA. $\mathrm{O}$ diagrama de fases dá o valor de $\mathrm{dV} / \mathrm{dt}$ em função do potencial de membrana. Neste diagrama é possível observar qual é o comportamento dos potenciais de ação para cada um dos estímulos, identificados por cores diferentes. As trajetórias no diagrama avançam do sentido horário, com picos dos potenciais de ação representados por $\mathrm{dV} /$ $\mathrm{dt}=0$. Através do diagrama construído é possível observar que a forma das curvas é bastante similar para cada uma das amplitudes de estímulo utilizadas, indicando que a 
Estudo computacional sobre a influência de sinapses elétricas entre bastonetes na faixa dinâmica escotópica da retina de vertebrados

forma dos potenciais de ação é conservada para toda a faixa de estímulos apesar da alteração na freqüência de disparos.

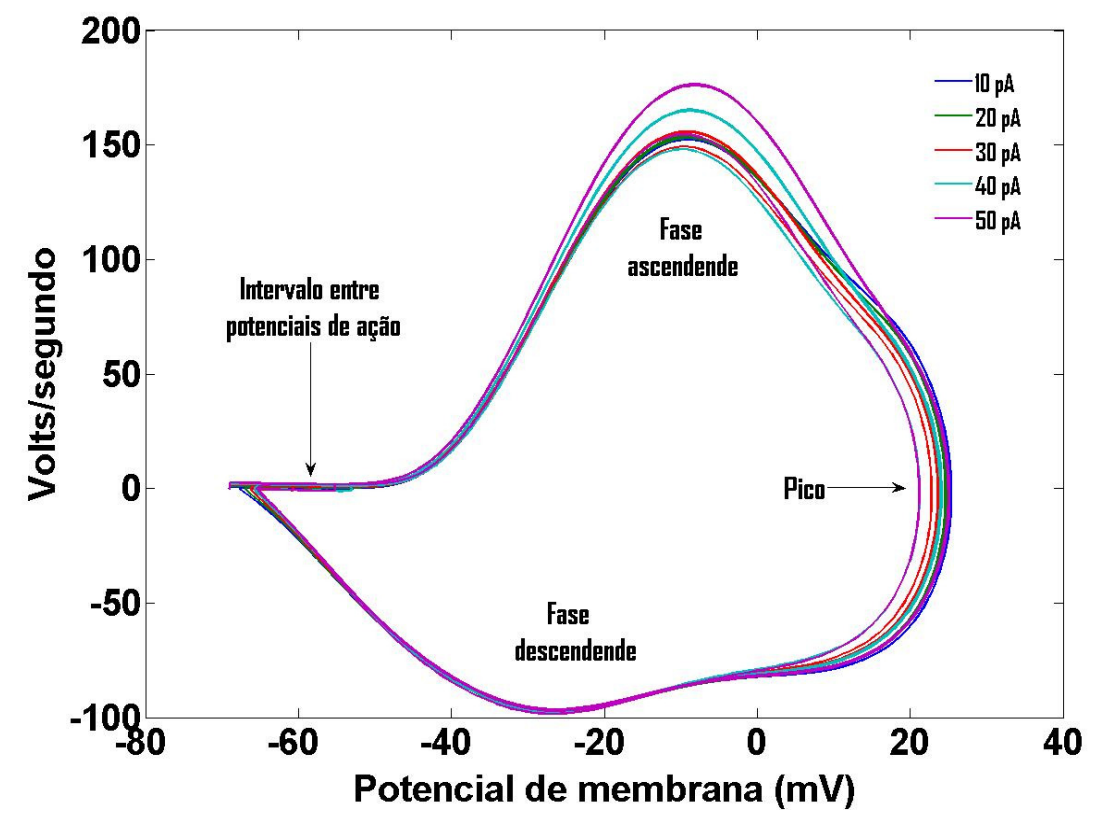

Figura 10. Diagrama de fase do modelo de célula ganglioar para os cinco valores indicados de amplitude do estímulo. As diferentes etapas de um potencial de ação estão indicadas no diagrama, onde cada cor representa a resposta obtida para uma determinada amplitude de estímulo.

O diagrama da figura 10 será utilizado como referência para a análise de como os diferentes mecanismos estudados neste trabalho, (1) a condutância do canal ativado pela hiperpolarização dos bastonetes e (2) o grau de conectividade entre os bastonetes, podem alterar a forma dos potencias de ação das células ganglionares e, como conseqüência, modificar a faixa dinâmica da retina.

\section{Receptores Sinápticos}

Os fotorreceptores e células bipolares da retina de vertebrados secretam glutamato como neurotransmissor. As sinapses responsáveis pela transmissão de sinais nos sistemas sensoriais através da liberação de glutamato, especificamente nos circuitos da visão e audição, são chamadas de sinapses ribbon. Esse tipo de sinapse transmite sinais analógicos cuja amplitude varia continuamente, assim como a taxa de liberação dos 
neurotransmissores nas vesículas pré-sinápticas. Em relação às sinapses convencionais, as sinapses ribbon possuem muito mais vesículas nos terminais para suportar a liberação continua de transmissores devido a mudanças graduais no potencial de membrana.

Ao invés de simular as conexões especializadas da retina de uma maneira dependente da concentração de cálcio (SIKORA et al., 2005), foi utilizado um modelo simplificado de sinapse analógica (BRIAM, 2003) com parâmetros ajustados para a retina de vertebrados. Esse modelo simplificado de sinapse ribbon foi adotado já que o custo computacional para a modelagem de uma única sinapse ribbon detalhada se mostrou elevado, sendo proibitivo para uma rede com pelo menos 1000 neurônios.

A implementação utilizada simula os dois receptores de glutamato presentes nos circuitos primário e secundário mediados pelos bastonetes: AMPA (Ácido $\alpha$-amino-3hidroxi-5-metilisoxazole-propriônico) e mGluR6. Os receptores metabotrópicos mGulR6 são encontrados nas células bipolares (AWATRAMANI \& SLAUGHTER, 2001), sendo ativados pelo glutamato liberado pelos receptores, enquanto os receptores AMPA são localizados nas células amácrinas e ganglionares (JACOBY \& WU, 2001; MUKAI et al., 2002). Esses dois receptores de glutamato foram modelados segundo a mesma estratégia, descrita a seguir.

A abertura de canais sinápticos é modelada por uma mudança na corrente sináptica dependente do tempo $\left(I_{\sin }(t)\right)$. Essa corrente possui uma condutância máxima $g_{\max }$ que está em série com uma bateria $E_{\sin }$ que gera o potencial e movimenta os íons envolvidos na ativação do canal. A corrente gerada pela ativação dos receptores é dada por:

$$
I_{\sin }(t)=g_{\max } S(t)\left(V(t)-E_{\text {sin }}\right)
$$

onde $g_{\max }$ é a condutância máxima da sinapse e $E_{\max }$ é o potencial de reversão da sinapse excitatória. A variável $S(t)$ determina o nível de ativação da sinapse. A sua variação com o tempo em função do potencial de membrana da célula pré-sináptica $V_{\text {pre }}$ é dada por:

$$
\frac{d S(t)}{d t}=\frac{S_{\infty}-S}{\left(1-S_{\infty}\right) \tau S} \quad \text { e } \quad S_{\infty}=\tanh \left(\frac{V_{p r e}-V_{t h}}{V_{\text {slope }}}\right)
$$


Estudo computacional sobre a influência de sinapses elétricas entre bastonetes na faixa dinâmica escotópica da retina de vertebrados

onde $V_{\text {th }}$ representa o limiar adotado em cada célula, ou seja, a partir de qual potencial de membrana o neurotransmissor será enviado enquanto $V_{\text {slope }}$ e $\tau$ são constantes dadas na tabela 15 .

Tabela 15. Parâmetros utilizados na modelagem dos canais sinápticos.

\begin{tabular}{l|l|l|l|l|l}
\hline Sinapse & $g_{\max }$ & $\tau$ & $V_{\text {slope }}$ & $E_{\text {sin }}$ & Referência \\
\hline AMPA e mGluR6 & $2.56 \mathrm{nS}$. & $10 \mathrm{~ms}$. & $10 \mathrm{mV}$. & $0,0 \mathrm{mV}$. & (SIKORA et al., 2005) \\
\hline
\end{tabular}

\section{Circuitos primário e secundário}

Os fotorreceptores respondem aos estímulos luminosos com uma hiperpolarização de membrana e essa resposta é transmitida até as células ganglionares do tipo ON-Beta através de circuitos paralelos, envolvendo as células bipolares dos cones e dos bastonetes. Ambos os circuitos convergem para as células ganglionares através das células bipolares dos cones, porém cada circuito opera em faixas distintas de intensidade luminosa. Para a construção da rede de neurônios simulando os circuitos primário e secundário mediados pelos bastonete, foi necessário, em uma primeira etapa, realizar uma ampla revisão bibliográfica com o objetivo de determinar quais dados são bem conhecidos sobre o padrão de conectividade na retina de vertebrados. Os dados coletados na literatura são apresentados no capítulo de revisão. Duas características importantes sobre o padrão de conectividade na retina que foram levadas em consideração para a construção do modelo são os fatores de convergência e divergência observados entre as camadas.

O alto número de bastonetes convergindo para cada célula ganglionar contribui para a extensão espacial de seu campo receptivo, além de contribuir para a resposta quase que contínua da célula ganglionar mesmo a baixas intensidades luminosas ou no escuro. A divergência do circuito contribui para criar novas cópias de um sinal captado por um único receptor, aumentando o número de sinapses químicas e amplificando o sinal (STERLING et al., 1988; VARDI \& SMITH, 1996). Um modelo realístico, cujo 
objetivo é simular os circuitos primário e secundário mediados pelos bastonetes, deve incorporar todos estes padrões de conectividade.

A rede foi construída a partir dos dados experimentais obtidos em um fragmento da retina de um gato adulto próximo a uma região cujo ponto central possui densidade máxima de cones e mínima de bastonetes, conhecida como area centralis, ou fóvea no caso dos primatas. A localização do fragmento retirado para análise está em torno de 0,4-0,5 mm de separação da area centralis, o que equivale a uma excentricidade de $2^{\circ}$ (STERLING et al., 1988). Apesar de muito próxima da area centralis, nessa região a densidade de cones já é bem inferior à densidade de bastonetes (RODIECK, 1988). As densidades de cada uma das células do circuito para a região analisada, bem como os fatores de convergência/divergência adotados, são dados nas tabelas 16 e 17.

Tabela 16. Densidades dos fotorreceptores para uma região a $2^{\circ}$ de excentricidade da area centralis. $\mathrm{O}$ número de neurônios indicado em cada caso é referente a uma região de $1 \mathrm{~mm}^{2}$. Dados retirados de STERLING et al., 1988.

\begin{tabular}{c|c|c|c|c|c}
\hline Cones & Bastonetes & $\begin{array}{c}\text { Bipolares } \\
\text { (Bastonetes) }\end{array}$ & $\begin{array}{c}\text { Bipolares } \\
\text { (Cones) }\end{array}$ & $\begin{array}{c}\text { Amácrinas } \\
\text { (AII) }\end{array}$ & Ganglionares (ON-Beta) \\
\hline 27000 & 450000 & 30300 & 6500 & 4100 & 2000 \\
\hline
\end{tabular}

Os fatores de convergência e divergência entre os neurônios de duas camadas distintas pode ser obtido a partir da razão entre as densidades de ambos os neurônios, considerando uma região específica da retina. Neste caso, a razão entre a convergência e divergência entre duas camadas pode ser dada por :

$$
\frac{A}{B}=\frac{\text { Convergência }}{\text { Divergência }}
$$

onde A é a densidade das células pré-sinápticas e B a densidade de células póssinápticas. O lado direito da igualdade representa a razão entre o número de células présinápticas conectadas com cada célula pós-sináptica e o número de células póssinápticas para uma pré-sináptica (FREED et al., 1987). É possível observar a partir dos dados apresentados na tabela 17 que o circuito primário mediado pelos bastonetes possui convergência e divergência bem maiores que o circuito mediado pelos cones. 
Estudo computacional sobre a influência de sinapses elétricas entre bastonetes na faixa dinâmica escotópica da retina de vertebrados

Uma das razões para essa diferença se deve à necessidade da amplificação da resposta dos bastonetes a estímulos de baixa intensidade luminosa.

Os valores de convergência apresentados na tabela 17 foram utilizados para determinar a dimensão da rede, ou seja, o número de células em cada camada foi determinado através dos valores apresentados nessa tabela. Dessa forma, a rede simulada contém 1500 bastonetes, 16 cones, 100 células bipolares dos bastonetes, 9 células amácrinas AII, 4 células bipolares dos cones e uma única célula ganglionar. Os valores de divergência foram utilizados para determinar o número conexões entre as camadas.

Tabela 17. Conexões estimadas nos circuitos primário e secundário para uma região a $2^{\circ}$ de excentricidade da area centralis. Dados adaptados de STERLING et al., 1988.

\begin{tabular}{c|c|c|c|c|c|c|c}
\hline & Bastonetes & Cones & $\begin{array}{c}\text { Bipolares } \\
\text { (Bastonetes) }\end{array}$ & $\begin{array}{c}\text { Amácrinas } \\
\text { (AII) }\end{array}$ & $\begin{array}{c}\text { Bipolares } \\
\text { (Cones) }\end{array}$ & $\begin{array}{c}\text { Ganglionares } \\
\text { (ON-Beta) }\end{array}$ \\
\hline $\begin{array}{c}\text { Circuito } \\
\text { Primário }\end{array}$ & Convergência & 1500 & ---- & 100 & 9 & 4 & 1 \\
\cline { 2 - 9 } & Divergência & 1 & ---- & 2 & 5 & 8 & 2 \\
\hline $\begin{array}{c}\text { Circuito } \\
\text { Secundário }\end{array}$ & Convergência & ---- & 16 & ---- & ---- & 4 & 1 \\
\cline { 2 - 9 } & Divergência & ---- & 1 & ---- & --- & 1 & 1 \\
\hline
\end{tabular}

Essas células foram arranjadas da seguinte maneira: os bastonetes foram organizados em uma rede retangular de 30x50 sítios, que será chamada de camada B; os cones foram dispostos em uma rede quadrada de $4 \times 4$ sítios, que será chamada de camada $\mathrm{C}$; as células bipolares dos bastonetes foram arranjados em uma rede quadrada de 10x10 sítios, que será denominada de camada BB; as células bipolares dos cones foram organizadas em uma rede quadrada de $2 \times 2$, que será denominada de camada $\mathrm{BC}$; e as células amácrinas AII foram arranjadas em uma rede quadrada de $3 \times 3$, que será chamada de camada AII. No caso dos receptores, os valores de convergência e divergência não estão representados na tabela 17 por serem neurônios pertencentes a uma mesma camada na retina de vertebrados.

O padrão de conexões entre as células dessas camadas está descrito a seguir (um diagrama mostrando o esquema de conexões do modelo da retina está mostrado na figura 11). 
Para as células da camada B, considerou-se que cada bastonete estabelece uma sinapse elétrica com cada um de seus quatro primeiros vizinhos com uma probabilidade $p$ que pode assumir os seguintes valores: $0,0,25,0,5,0,75$ e 1 . O primeiro e o último casos são deterministas e correspondem às situações em que os bastonetes estão, respectivamente, desacoplados ou totalmente acoplados a seus primeiros vizinhos. Os outros três casos correspondem às situações em que os bastonetes estão conectados em média a, respectivamente, um, dois ou três de seus primeiros vizinhos. Neste trabalho, o número médio de conexões por sinapses elétricas entre um neurônio e seus primeiros vizinhos em uma rede quadrada será indicado por um índice de conectividade ( $\kappa)$ cujos valores são $\kappa=0,1,2,3$ e 4 .

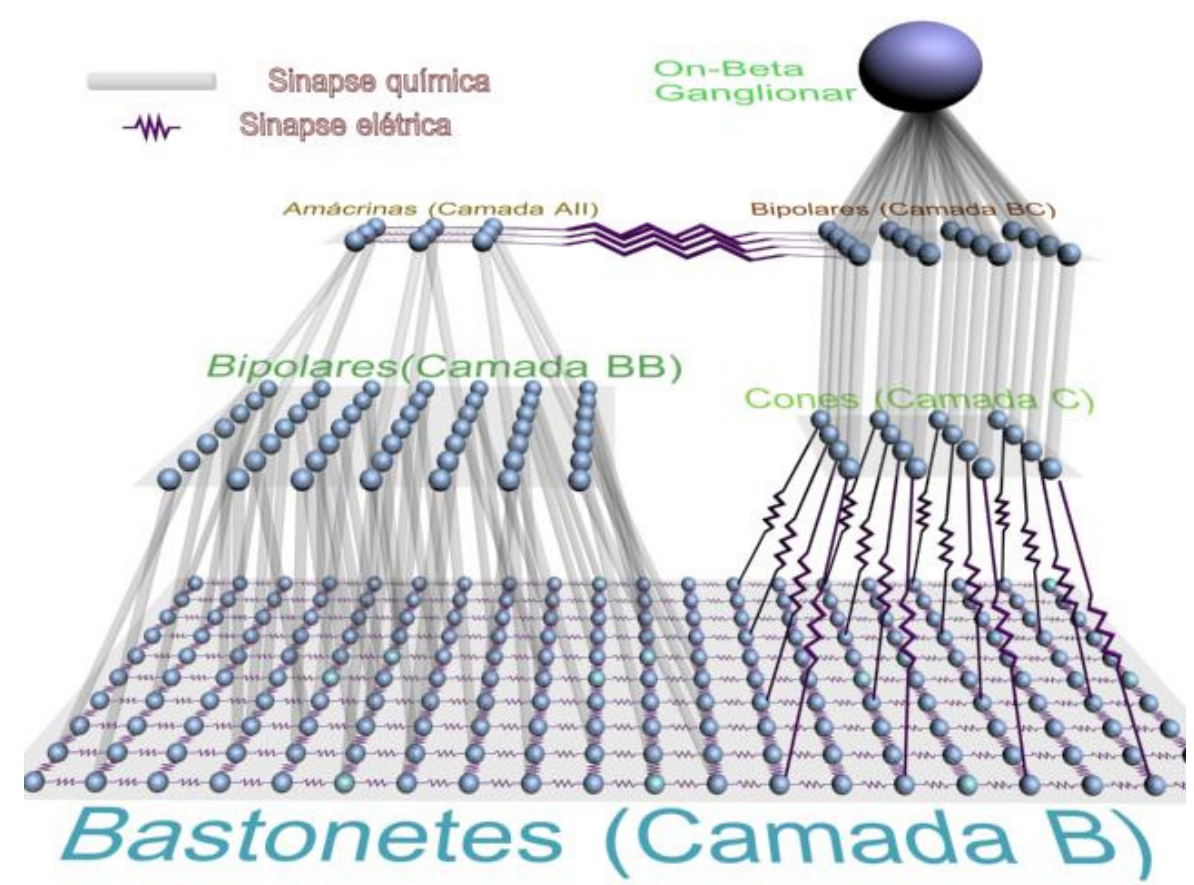

Figura 11. Estrutura do modelo de retina. Cada bastonete se conecta com os seus primeiros vizinhos de acordo com o valor do índice de conectividade $\mathrm{K}$. Ainda de acordo com este mesmo índice, cada cone se conecta, em média, com $\mathrm{k}$ bastonetes aleatórios da rede de bastonetes e cada célula amácrina AII se conecta, em média, com seus $\mathrm{K}$ primeiros vizinhos. Os valores de divergência entre as camadas são utilizado para determinar o número de sinapses químicas, e estão representados na tabela 17.

Para as sinapses elétricas entre os bastonetes e os cones, considerou-se que cada bastonete faz, em média, o mesmo número $\kappa$ de conexões com os cones do que com os seus primeiros vizinhos na rede B. Ou seja, cada bastonete pode realizar, em média, conexões com um número de cones, aleatoriamente selecionados, que pode variar de zero $(\kappa=0)$ até quatro $(\kappa=4)$. Por exemplo, para $\kappa=2$ cada bastonete realiza, em média, conexões com 2 cones aleatoriamente selecionados da camada $\mathrm{C}$. 
Estudo computacional sobre a influência de sinapses elétricas entre bastonetes na faixa dinâmica escotópica da retina de vertebrados

Este padrão de conectividade foi adotado pois não há motivos para supor que, caso um bastonete faça sinapses elétricas com células vizinhas, elas sejam feitas exclusivamente com outros bastonetes (ZHANG \& WU, 2005). Embora no modelo os bastonetes e os cones estejam em camadas distintas (B e C), isto foi feito assim apenas para simplificar sua implementação computacional. Na camada camada nuclear externa da retina, porém, bastonetes e cones compartilham o mesmo espaço e é natural supor que os bastonetes tenham junções gap com bastonetes e cones de forma indistinta. Em princípio, os índices de conectividade para as conexões entre bastonetes e entre bastonetes e cones são diferentes, mas aqui considerou-se o mesmo valor de $\kappa$ para os dois tipos de conexão por uma questão de simplificação do código computacional usado para a implementação do modelo.

O padrão de conectividade entre as células da camada AII foi determinado da mesma maneira que a feita para as células da camada $B$. Isto é, o número médio de conexões entre cada célula amácrina e seus primeiros vizinhos foi estabelecido por um índice de conectividade $\kappa$, não necessariamente igual ao utilizado na camada receptora.

Para as sinapses elétricas entre as células bipolares dos cones e as amácrinas AII, seguiu-se aproximadamente o fator de divergência apresentado na tabela 17. Para cada célula da camada AII, duas células da camada BC foram escolhidas aleatoriamente e sinapses elétricas foram estabelecidas entre elas.

De acordo com a topologia adotada em cada uma das camadas, as células pertencentes às fronteiras realizam um número de conexões por sinapses elétricas igual a $\kappa-1$.

Com relação às sinapses químicas, considerou-se que: (1) cada bastonete da camada B se conecta com duas células da camada BB escolhidas ao acaso; (2) cada cone da camada $\mathrm{C}$ se conecta com uma célula da camada BC escolhida aleatoriamente; (3) cada célula bipolar dos bastonetes da camada BB se conecta com três células amácrinas aleatoriamente selecionadas da camada AII; e (4) as quatro células bipolares do cone da camada $\mathrm{BC}$ se conectam com a célula ganglionar.

As condutâncias das sinapses elétricas foram ajustadas seguindo as referências experimentais disponíveis. Os valores das condutâncias sinápticas utilizadas no modelo são apresentados na tabela 18 , com as referências relativas a cada um dos parâmetros apresentadas na última coluna desta mesma tabela. 
Tabela 18. Condutâncias das sinapses elétricas presentes no modelo dos circuitos primário e secundário.

\begin{tabular}{c|c|c}
\hline & Condutância (nS) & Referências \\
\hline Bastonetes-Bastonetes & 0,5 & (ZHANG \& WU, 2005) \\
\hline Bastonetes-Cones & 0,2 & (ZHANG \& WU, 2005) \\
\hline Amácrinas-Amácrinas & 0,2 & (SMITH \& VARDI, 1995) \\
\hline $\begin{array}{c}\text { Amácrinas-Bipolares dos } \\
\text { cones }\end{array}$ & 0,2 & (SMITH \& VARDI, 1995) \\
\hline
\end{tabular}

Os resultados mais recentes mostram que as intensidades dos acoplamentos elétricos entre cones e bastonetes e entre bastonetes são bem semelhantes (ZHANG \& WU, 2005), indicando um acoplamento fraco na camada receptora. Esse acoplamento fraco pode ser desejável, já que isso garante que apenas uma pequena fração de um dado sinal recebido por um receptor será transmitida para os seus vizinhos permitindo que cada célula continue a responder aos estímulos luminosos sem apresentar saturação (ZHANG \& WU, 2005). Além do acoplamento elétrico na camada receptora, as sinapses elétricas estão presentes entre as células amácrinas AII e entre as células amácrinas AII e células bipolares dos cones (SMITH \& VARDI, 1995; DEANS et al., 2002; VOLGYI et al., 2004). No caso das sinapses elétricas presentes entre as células amácrinas, foram utilizados valores para as condutâncias ajustados para se obter a melhor relação sinal/ruído (SMITH \& VARDI, 1995). Em todos os casos, o acoplamento elétrico foi simulado conectando as células vizinhas através de uma resistência elétrica igual em ambas as direções.

No modelo, o índice de conectividade pode ser alterado, tanto na camada receptora quanto na camada de células amácrinas de forma independente, possibilitando uma análise do papel das sinapses elétricas em cada etapa do sistema visual periférico. No próximo capítulo são apresentados os resultados referentes a simulações, primeiramente, de partes do modelo completo contendo apenas partes de algumas de suas camadas, e, posteriormente, do modelo completo. 
Estudo computacional sobre a influência de sinapses elétricas entre bastonetes na faixa dinâmica escotópica da retina de vertebrados

\section{Capítulo IV}

\section{Resultados}

O modelo de retina descrito no capítulo anterior foi implementado utilizando o neurosimulador NEURON 6.0 (HINES \& CARNEVALE, 1997; CARNEVALE \& HINES., 2006) rodando em sistema LINUX (kernel 2.6.22). Os experimentos descritos neste capítulo foram rodados em um cluster de microcomputadores (PC) com 10 nós equipados com processador Pentium Intel $4^{\mathrm{TM}}, 3 \mathrm{GHz}$, com $2 \mathrm{~Gb}$ de memória RAM. O método numérico padrão do NEURON utilizado para a resolução do sistema de equações diferenciais é o método de Crank-Nicolson com passo de integração de $10^{-5} \mathrm{~s}$. Os potenciais de membrana dos bastonetes, células bipolares e ganglionares foram registrados para todas as diferentes configurações da rede possibilitando a análise da faixa dinâmica em diferentes etapas do processamento visual.

Neste capítulo, os resultados obtidos com o modelo em vários experimentos são comparados a dados retirados da literatura. $\mathrm{O}$ primeiro e o segundo experimentos têm como objetivo principal investigar como a condutância do canal ativado pela hiperpolarização de membrana e a presença de sinapses elétricas entre os bastonetes podem alterar a faixa dinâmica medida para um bastonete isolado e para a camada receptora de bastonetes. No segundo experimento observa-se que a faixa dinâmica é maximizada na camada receptora quando o índice de conectividade entre os receptores é igual ao valor crítico para que haja percolação de ligação em uma rede quadrada, $\kappa=$ 2 (GRIMMETT, 1999).

No terceiro experimento, os mesmos mecanismos investigados na camada receptora foram também investigados na camada de células bipolares dos bastonetes, considerando os padrões de convergência e divergência entre as camadas. Quando a faixa dinâmica é medida na camada $\mathrm{BB}$, observa-se o valor máximo para um índice de conectividade entre os bastonetes inferior ao valor crítico para percolação de ligação. Estes resultados sugerem que um alto valor para o índice de conectividade na camada receptora pode elevar o nível de excitação médio dos bastonetes, causando uma saturação antecipada das sinapses químicas entre receptores e células bipolares e reduzindo a faixa dinâmica desses últimos. 
O quarto experimento se refere aos resultados obtidos através de medidas realizadas na célula ganglionar, considerando o modelo completo com os circuitos primário e secundário descritos no capítulo anterior. Neste experimento a mesma variação no índice de conectividade e na condutância do canal $\mathrm{I}_{\mathrm{h}}$ foi utilizada para a camada receptora e para a camada de células amácrinas AII. Os resultados obtidos mostram que é possível maximizar a faixa dinâmica da retina quando os receptores estão acoplados com um índice de conectividade subcrítico igual a 1. Além disso, os resultados sugerem que alterações na faixa dinâmica podem ser causadas por uma combinação de mecanismos intracelulares e por diferentes padrões de conectividade.

\section{Experimento I: Faixa Dinâmica do Bastonete}

O modelo compartimental do bastonete possui 6 tipos de correntes iônicas com dinâmicas distintas umas das outras, conforme a descrição no capítulo anterior. Algumas evidências experimentais e teóricas (BAYLOR et al., 1984 ; KAMIYAMA et al., 1996) mostram que a corrente $I_{h}$ pode alterar significativamente a amplitude e a forma do potencial de membrana da célula em resposta a um estímulo. Em condições normais, a corrente $I_{h}$ é ativada à medida que a membrana se torna hiperpolarizada, moldando o transiente inicial do potencial de membrana. Na presença do bloqueador da corrente $\mathrm{I}_{\mathrm{h}}$ (césio) o bastonete deixa de apresentar o transiente inicial característico de sua resposta, mostrando uma resposta constante para estímulos de alta intensidade. Além disso, o bloqueio da corrente $\mathrm{I}_{\mathrm{h}}$ provoca um deslocamento temporal no pico de resposta e um aumento na sua amplitude. A maioria desses resultados são reproduzidos pelo modelo do bastonete descrito anteriormente e apresentados na figura 12.

É possível observar ainda que a ausência da corrente $I_{h}$ faz com que a amplitude da resposta máxima para estímulos de alta intensidade aumente em relação ao caso em que nenhum tipo de bloqueio é utilizado. Para verificar como diferentes condutâncias do canal ativado pela hiperpolarização podem influenciar na amplitude de resposta do bastonete e, conseqüentemente, em sua faixa de resposta, uma nova simulação foi feita, desta vez variando-se a condutância desse canal em passos de $0,5 \mathrm{nS}$. Os resultados dessa simulação estão apresentados na figura 13. No modelo do neurônio isolado, o bloqueio total ou parcial da corrente $\mathrm{I}_{\mathrm{h}}$ só começa a alterar significativamente o pico de resposta para estímulos a partir de $40 \mathrm{pA}$, resultado compatível com as evidências 
Estudo computacional sobre a influência de sinapses elétricas entre bastonetes na faixa dinâmica escotópica da retina de vertebrados

disponíveis na literatura, em que a amplitude máxima da fotocorrente observada experimentalmente situa-se na faixa de 40 pA a 50 pA (BAYLOR et al., 1984).
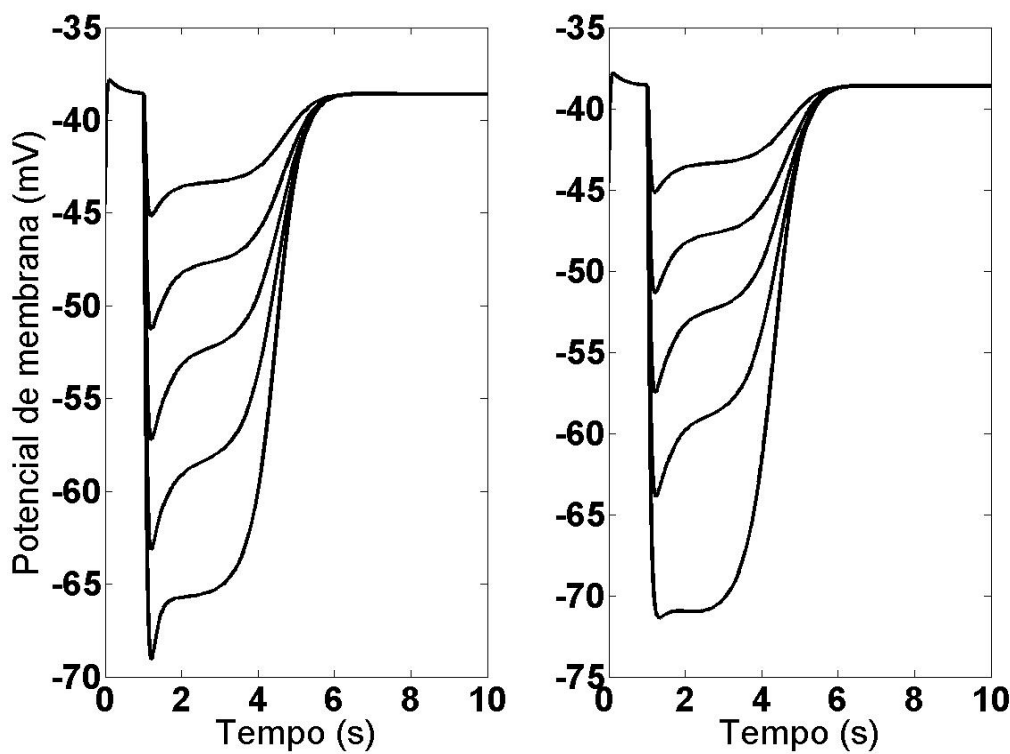

Figura 12. Respostas simuladas à fotocorrente. O gráfico da esquerda mostra o potencial de membrana do bastonete em resposta ao estímulo na presença da corrente $I_{h}$, enquanto o gráfico da direita mostra o potencial de membrana do bastonete em resposta ao estímulo com a corrente $I_{h}$ completamente bloqueada. Para ambos os casos uma série de fotocorrentes (figura 6) de amplitude variando de $10 \mathrm{pA}$ a $50 \mathrm{pA} \mathrm{em}$ passos de 10 pA e duração 6 s foi aplicada.

A presença da corrente $I_{h}$ está diretamente relacionada a uma alteração significativa no pico de resposta do modelo de bastonete para estímulos na faixa de $40 \mathrm{pA}$ a $50 \mathrm{pA}$, reduzindo o pico máximo de resposta, conforme mostrado na figura 13 , e tendo como conseqüência a possível prevenção da saturação das sinapses feitas pelo bastonete. Esse resultado sugere que mecanismos intracelulares, como a corrente ativada pela hiperpolarização, podem contribuir para um aumento da faixa dinâmica de neurônios isolados prevenindo a saturação de suas respostas a estímulos de alta intensidade. Para testar como a condutância do canal $\mathrm{I}_{\mathrm{h}}$ pode alterar a faixa dinâmica do bastonete, sua faixa dinâmica foi calculada pelas equações 11 e 12 e os resultados apresentados na figura 14. 


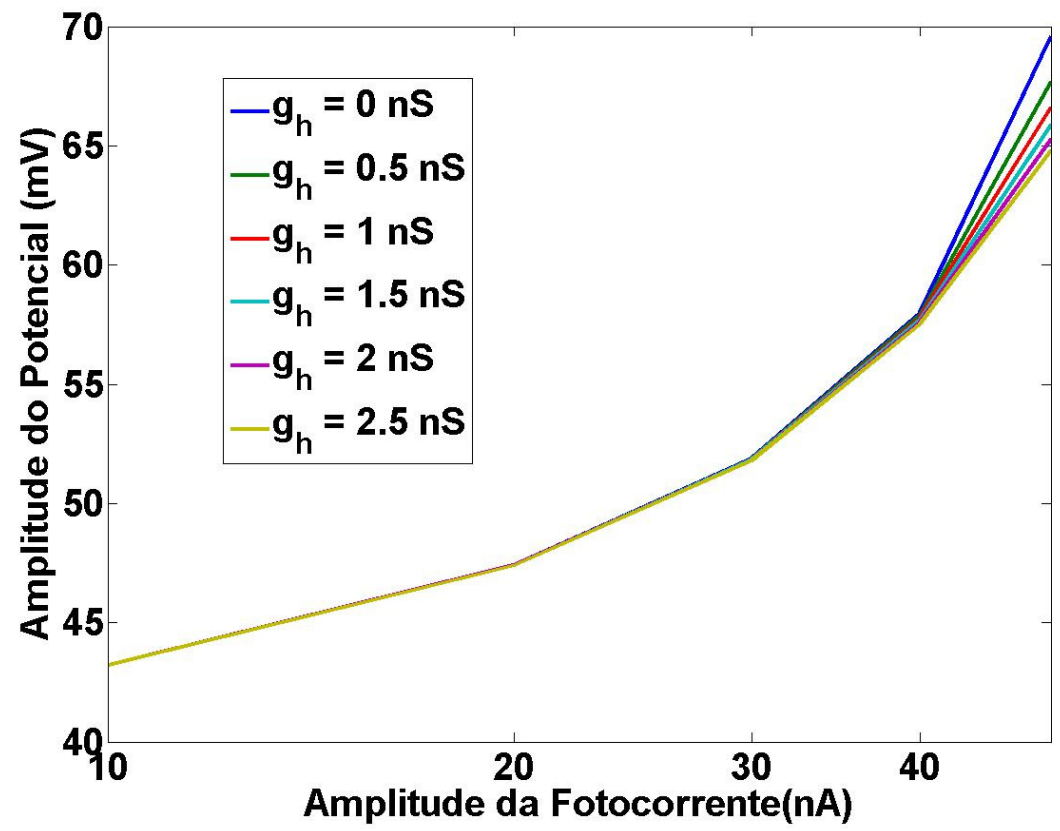

Figura 13. Gráfico em escala linear-log do pico de resposta do potencial de membrana do modelo de bastonete para diferentes níveis de bloqueio do canal ativado pela hiperpolarização $\mathrm{I}_{\mathrm{h}}$ em função da amplitude da fotocorrente aplicada ao bastonete.

A presença da corrente $I_{h}$ no modelo do bastonete isolado possibilitou um aumento na sua faixa dinâmica. Apesar dos resultados sugerirem a possibilidade de um mecanismo intracelular participar no aumento da faixa dinâmica do receptor isolado, é possível observar que a variação na faixa dinâmica é muito pequena. Apesar disso, o acoplamento elétrico e a presença de outras camadas de neurônios podem potencializar o papel desta corrente na faixa dinâmica da retina. A única forma de determinar o efeito desse mecanismo em uma rede de larga escala é por outras simulações computacionais que levem em consideração os diferentes circuitos mediados pelos bastonetes. Nos próximos experimentos, o papel da corrente $I_{h}$ na amplificação da faixa dinâmica dos neurônios estudados será investigado em paralelo com o papel do índice de conectividade $\kappa$ entre as células. 
Estudo computacional sobre a influência de sinapses elétricas entre bastonetes na faixa dinâmica escotópica da retina de vertebrados

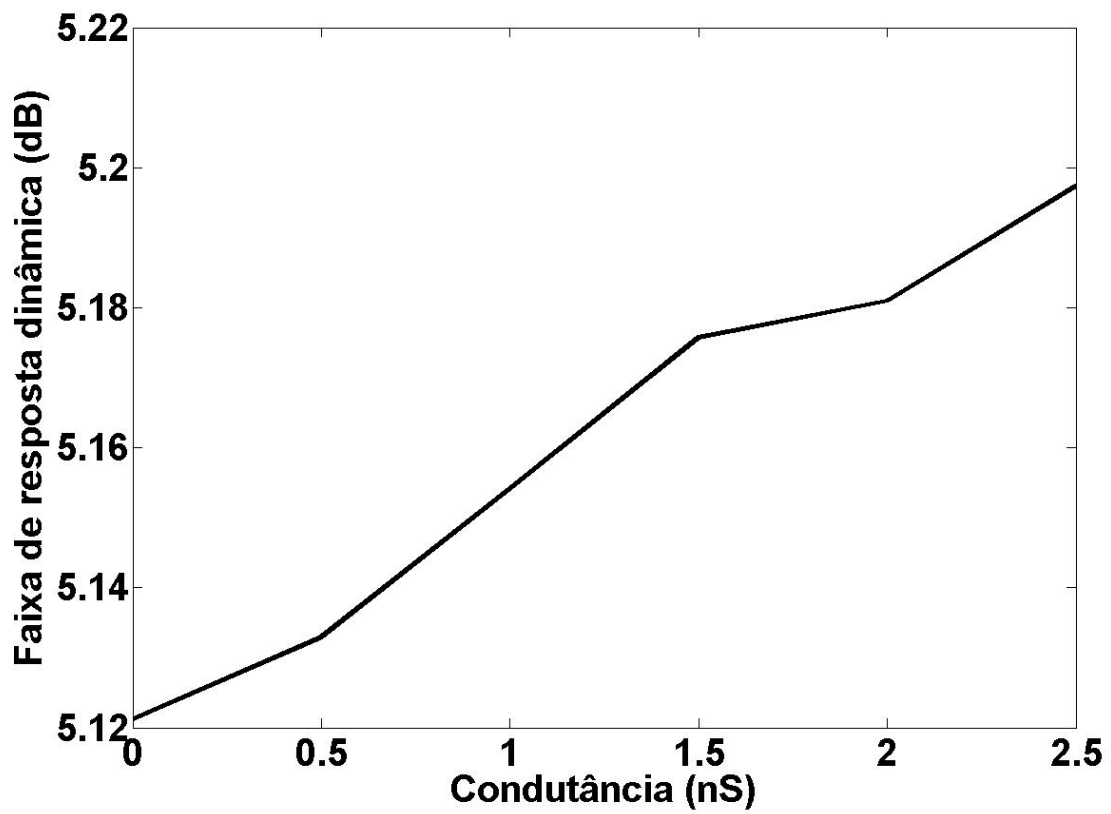

Figura 14. Faixa de resposta dinâmica do bastonete isolado em função da condutância do canal ativado pela hiperpolarização $\mathrm{I}_{\mathrm{h}}$ da membrana.

\section{Experimento II: Rede de Bastonetes}

Neste experimento considerou-se apenas um pedaço da rede de bastonetes descrita no capítulo anterior, composto por 144 bastonetes distribuídos em uma rede quadrada de $12 \times 12$ sítios. Com exceção das fronteiras, cada bastonete se conecta por sinapses elétricas, em média, com até 4 de seus primeiros vizinhos de acordo com um índice de conectividade $\kappa$. Todas as sinapses elétricas têm resistências iguais a $2000 \mathrm{M} \Omega$ (ZHANG \& WU, 2005).

Ao início de cada simulação, considera-se que todas as células da rede encontram-se em suas condições de equilíbrio. O modelo utilizado para o estímulo luminoso representa um flash apresentado para toda a rede, onde o número mínimo de bastonetes que efetivamente absorvem o estímulo corresponde a $25 \%$ do total de receptores e o número máximo corresponde a $50 \%$ do total. A fração de bastonetes que absorvem o estímulo foi escolhida nessa faixa por ela ser semelhante à probabilidade de absorção de um fóton pelos fotorreceptores, considerando o comprimento do segmento externo dos bastonetes na salamandra tigre (PUGH \& LAMB, 2000). Nas simulações considerou-se que para cada bastonete que absorve o estímulo uma fotocorrente descrita pela equação 13, cuja amplitude é dependente da intensidade do estímulo, é inserida em seu compartimento. 


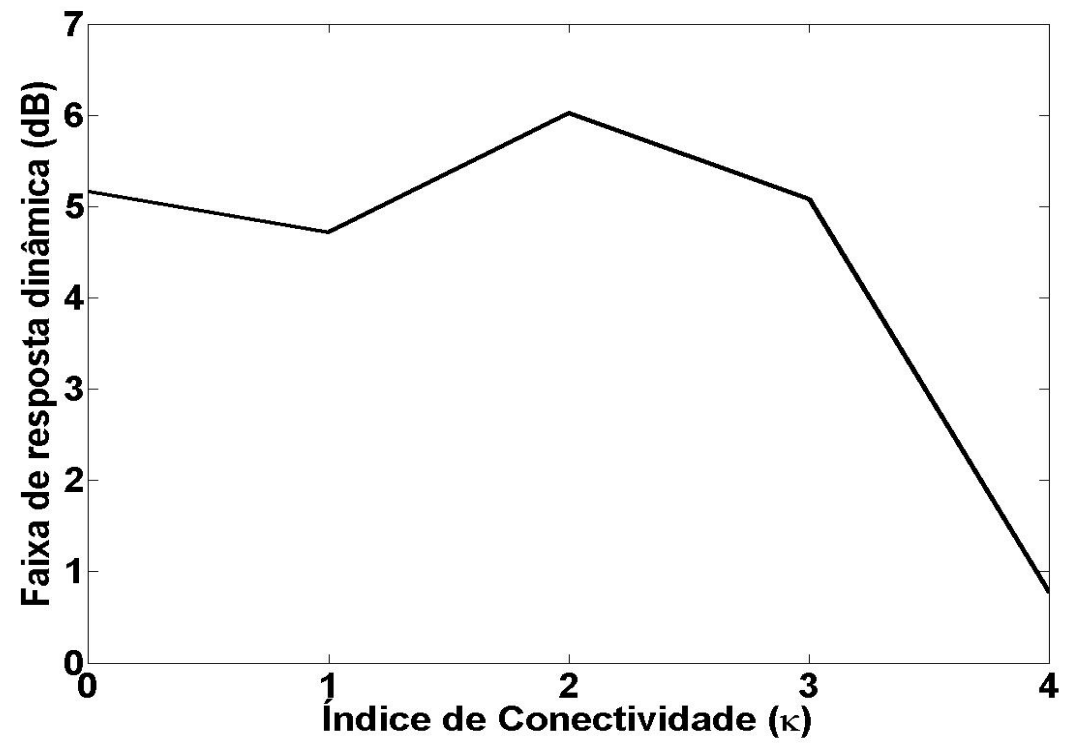

Figura 15. Faixa dinâmica da rede de bastonetes em função do índice de conectividade da rede. Para todos os casos uma condutância de 0.5 nS para o canal $I_{h}$ foi adotada.

A faixa dinâmica do modelo da rede de bastonetes está apresentada na figura 15 . Para a construção desse gráfico, a amplitude da fotocorrente variou de 10 a 50 pA em passos de $10 \mathrm{pA}$ e a correspondente resposta da rede foi determinada pelo cálculo da média do pico do potencial de membrana de todos os bastonetes na rede. Esse procedimento foi repetido para valores do índice de conectividade $\kappa$ da rede entre 0 e 4 , permitindo a avaliação do papel desse índice sobre a faixa dinâmica da rede. Em todas as simulações, a condutância $\mathrm{g}_{\mathrm{ih}}$ do canal $\mathrm{I}_{\mathrm{h}}$ dos bastonetes foi mantida em $0,5 \mathrm{nS}$.

Os resultados da figura 15 mostram que a faixa dinâmica só é amplificada quando comparada ao caso desacoplado para o caso $\kappa=2$, que corresponde ao grau de acoplamento crítico para que haja percolação de ligação em uma rede quadrada (GRIMMETT, 1999).

Para verificar o efeito combinado do índice de conectividade $\kappa$ e da condutância $g_{\text {ih }}$ do canal $\mathrm{I}_{\mathrm{h}}$ sobre a faixa dinâmica da rede de bastonetes, o experimento descrito acima foi repetido para todas as combinações possíveis entre $\kappa$ e valores de $g_{i h}$ dentro de uma faixa de valores que está de acordo com os dados disponíveis na literatura (KAMIYAMA et al., 1996 ; MAO et al., 2003; LIU \& KOURENNYI., 2004). O resultado está dado no diagrama da figura 16. 
Estudo computacional sobre a influência de sinapses elétricas entre bastonetes na faixa dinâmica escotópica da retina de vertebrados

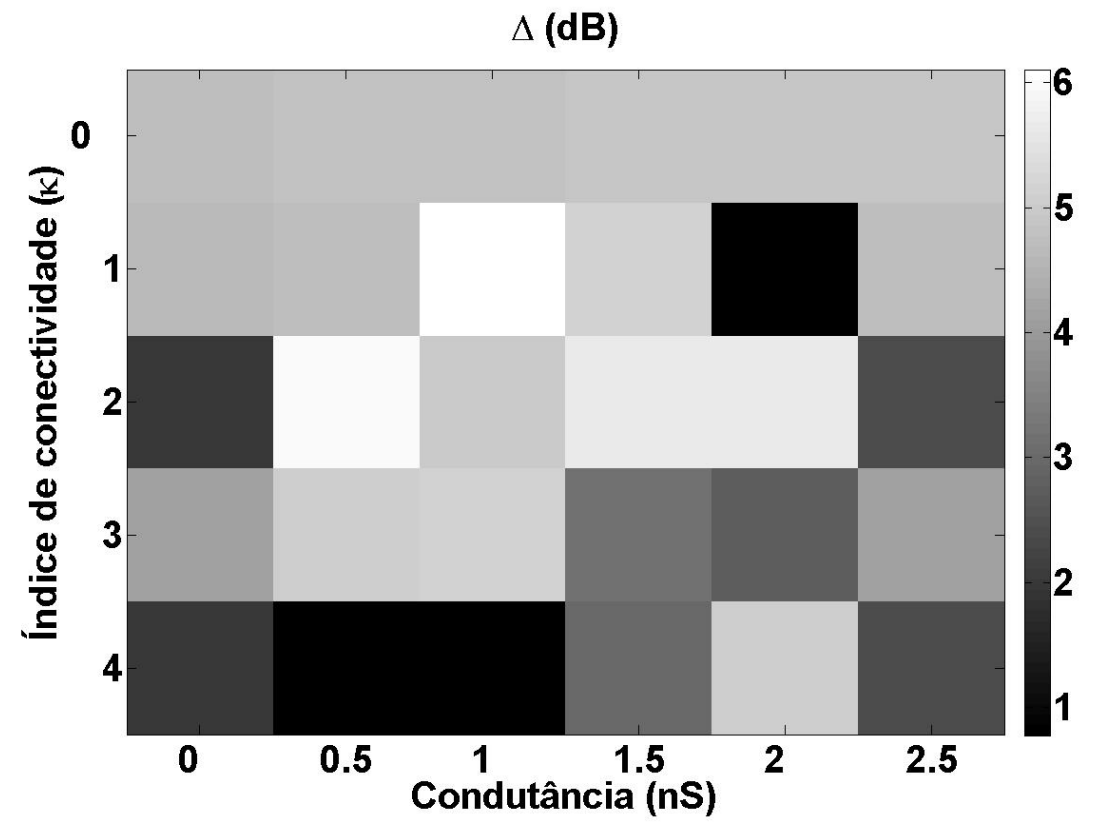

Figura 16. Faixa dinâmica da rede de bastonetes em função do índice de conectividade $\kappa$ da rede e da condutância $\mathrm{g}_{\text {ih }}$ do canal ativado pela hiperpolarização de membrana.

Os resultados das simulações com as diferentes combinações entre $\kappa$ e $g_{\text {ih }}$ mostram que existe uma região restrita de parâmetros em que a faixa dinâmica da rede de bastonetes é maximizada. Especificamente, os picos na faixa dinâmica ocorrem para apenas dois casos: (1) $\kappa=1$ e $g_{i h}=1 \mathrm{nS}$ e (2) $\kappa=2$ e $g_{\text {ih }}=0,5 \mathrm{nS}$.

Esses resultados sugerem que o sistema trabalha com uma combinação bem ajustada de parâmetros para maximizar a sua faixa dinâmica. Nos dois casos, pequenas variações na condutância do canal $I_{h}$ reduzem a faixa dinâmica da rede de bastonetes. Em particular, o bloqueio do canal $\mathrm{I}_{\mathrm{h}}$ dos bastonetes reduz a faixa dinâmica. Os resultados também mostram que é possível que a rede de bastonetes tenha uma faixa dinâmica máxima para um índice a conectividade subcrítico $(\kappa=1)$, desde que a condutância do canal $\mathrm{I}_{\mathrm{h}}$ tenha um valor apropriado.

Os resultados sugerem, portanto, que um mecanismo intracelular que já havia se mostrado relevante em modelar o potencial de membrana dos bastonetes isolados pode interagir com o padrão de conectividade da rede para permitir uma modulação da sua faixa dinâmica, possibilitando a ocorrência do valor ótimo dessa faixa dinâmica tanto para a condição crítica como para uma condição subcrítica. 
A alta convergência da camada receptora para as células bipolares e a presença de sinapses elétricas em outras camadas da retina podem ser outros fatores que possam alterar a faixa dinâmica da retina. Para testar o efeito desses fatores foram realizados outros dois experimentos apresentados a seguir.

\section{Experimento III: Rede Bastonete-Bipolar.}

Neste experimento o modelo utilizado é novamente apenas uma parte do modelo completo descrito no capítulo anterior. Ele é formado apenas por duas camadas de células, uma de bastonetes e a outra de células bipolares dos bastonetes. A rede de bastonetes é a mesma do experimento 2, composta por 144 células arranjadas em uma rede quadrada, e a rede de células bipolares dos bastonetes é constituída por 9 células arranjadas em uma rede quadrada de $3 \times 3$ sítios. Esses números de células preservam de forma aproximada o fator de convergência da tabela 17 . O padrão de divergência também foi mantido, de maneira que cada bastonete realiza conexão por sinapses químicas com 2 células bipolares (STERLING et al., 1988).

O mesmo padrão de conectividade utilizado no experimento anterior para a camada receptora é utilizado neste experimento, onde o número de bastonetes que efetivamente absorvem o estímulo está entre $25 \%$ e $50 \%$ do total de receptores. No início de cada simulação, cada um dos bastonetes selecionados aleatoriamente recebe a fotocorrente usada para o experimento.

Os potenciais de membrana de um bastonete e de uma célula bipolar do bastonete que recebe uma sinapse química do primeiro estão mostrados na figura 17, para diferentes valores de fotocorrente aplicados ao bastonete. Os resultados da figura 17 mostram uma saturação da resposta da célula bipolar para estímulos de amplitude acima de $40 \mathrm{pA}$, valor muito próximo dos encontrados na literatura para a amplitude da fotocorrente quando os receptores são submetidos a flashs de alta intensidade luminosa (BAYLOR et al., 1984 ; JONES, 1995), o que justifica a utilização desse valor como a máxima amplitude utilizada em todas as simulações. 
Estudo computacional sobre a influência de sinapses elétricas entre bastonetes na faixa dinâmica escotópica da retina de vertebrados
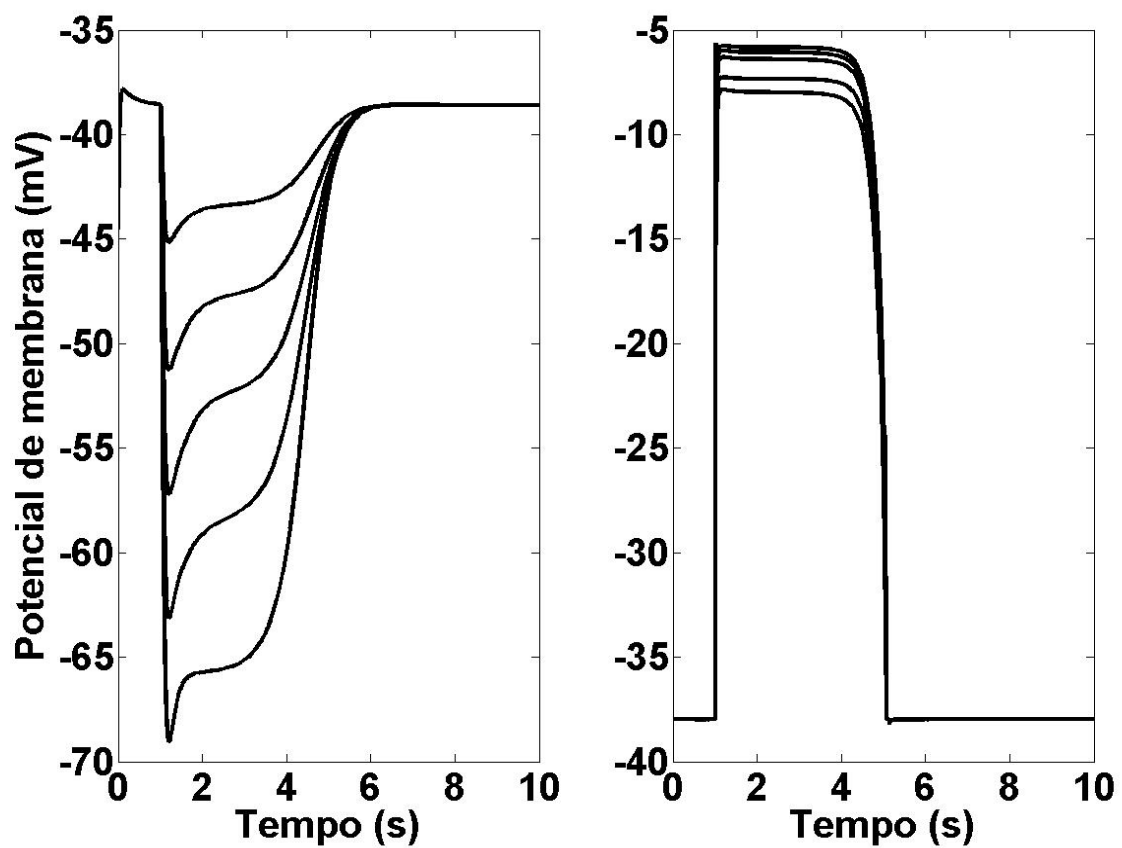

Figura 17. Potencial de membrana em função da amplitude da fotocorrente de entrada (mesmas fotocorrentes da figura 6 , com amplitudes variando de $10 \mathrm{pA}$ a $50 \mathrm{pA}$ em passos de $10 \mathrm{pA}$ ) para um bastonete (esquerda) e uma célula bipolar do bastonete (direita). O bastonete faz uma sinapse química sobre a célula bipolar.

Para verificar a influência do padrão de conectividade da rede de bastonetes e da condutância do canal $I_{h}$ dos bastonetes sobre a faixa dinâmica da rede de células bipolares dos bastonetes, uma busca extensiva no espaço de parâmetros $\left(\kappa, \mathrm{g}_{\text {ih }}\right)$ foi realizada. Para cada valor utilizado para a amplitude da fotocorrente, a resposta da rede de células bipolares foi determinada pelo cálculo da média do pico do potencial de membrana das células bipolares. Os resultados estão mostrados no diagrama da figura 18, que dá a faixa dinâmica da rede de células bipolares em função das diferentes combinações de $\kappa$ e $g_{\text {ih }}$.

Segundo esses resultados, a faixa dinâmica das células bipolares é máxima somente para o caso de acoplamento subcrítico $(\kappa=1)$ entre os bastonetes, tanto para $\mathrm{g}_{\mathrm{ih}}=0,5 \mathrm{nS}$ como para $g_{\text {ih }}=1 \mathrm{nS}$. Diferentemente do caso da rede de bastonetes, em que a redução de $g_{\text {ih }}$ de $1 \mathrm{nS}$ para $0,5 \mathrm{nS}$ forçava a conectividade $\kappa$ da rede para a criticalidade $(1 \rightarrow 2)$ para que a faixa dinâmica continuasse no máximo, neste caso a mesma redução em $\mathrm{g}_{\mathrm{ih}}$ não requer qualquer alteração na conectividade para manter a faixa dinâmica no máximo. Pelo contrário, o aumento de $\kappa$ em direção ao valor crítico provoca agora uma redução na faixa dinâmica das células bipolares. 


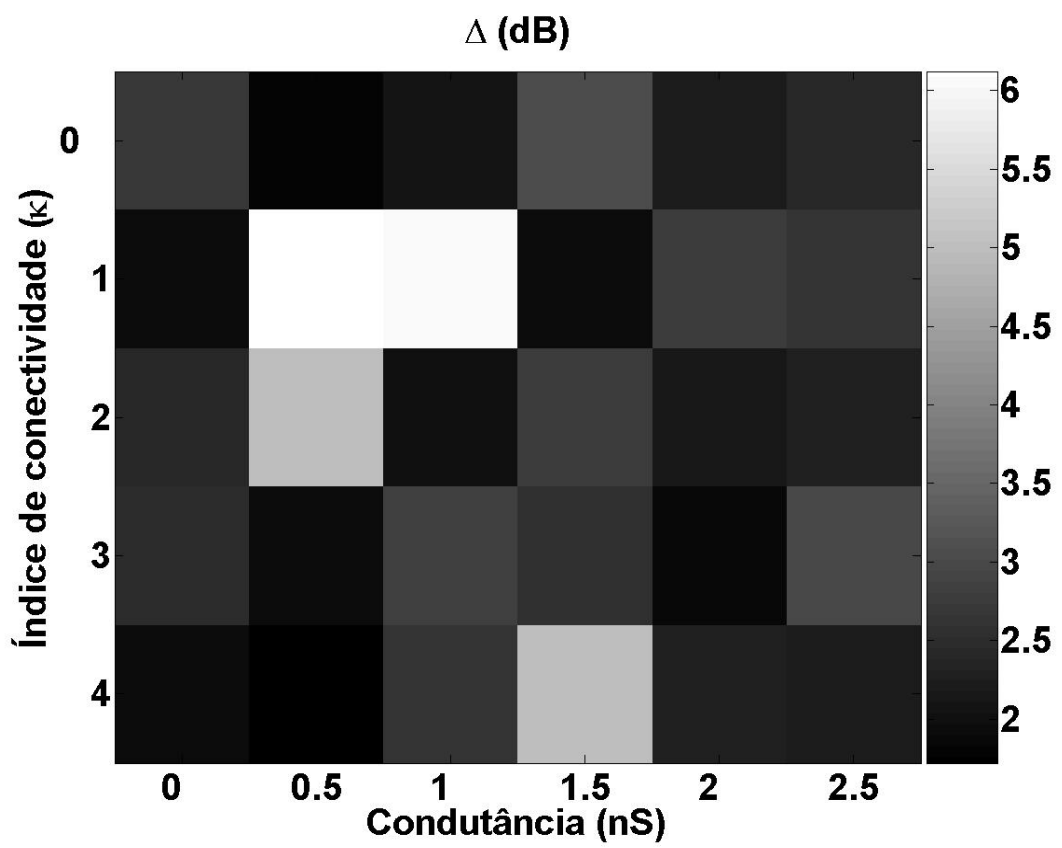

Figura 18. Faixa dinâmica da rede de células bipolares dos cones em função do índice de conectividade da rede de bastonetes e da condutância do canal $\mathrm{I}_{\mathrm{h}}$ dos bastonetes.

Para melhor visualizar o efeito do índice de conectividade da camada de bastonetes sobre a faixa dinâmica da camada de células bipolares dos bastonetes para os dois casos de interesse com relação à condutância do canal $\mathrm{I}_{\mathrm{h}}\left(\mathrm{g}_{\mathrm{h}}=0,5 \mathrm{nS}\right.$ e $\left.1 \mathrm{nS}\right)$, foram construídos os gráficos da figura 19. Esses gráficos permitem observar a existência de um pico pronunciado no valor da faixa dinâmica quando $\kappa=1$ para os dois valores de condutância indicados.

No caso desacoplado $(\kappa=0)$ o número de bastonetes ativados é pequeno, uma vez que o sinal não irá se espalhar por toda camada receptora, reduzindo a eficácia da alta convergência que existe entre as duas primeiras camadas do circuito primário. Dessa forma, a faixa dinâmica da segunda camada também será reduzida, pois a rede torna-se menos sensível a estímulos de baixa intensidade luminosa. Entre os casos acoplados $(\kappa>0)$, o pico na faixa dinâmica observado quando cada bastonete está conectado em média com apenas um de seus primeiros vizinhos pode estar relacionado com o fato de que uma antecipação na saturação das células bipolares pode ser provocada se a maioria dos bastonetes forem ativados, como será o caso quando $\kappa>1$. Com muitos bastonetes ativados, o alto grau de convergência da camada receptora para as células bipolares pode provocar a saturação dos receptores sinápticos nas células bipolares. 
Estudo computacional sobre a influência de sinapses elétricas entre bastonetes na faixa dinâmica escotópica da retina de vertebrados
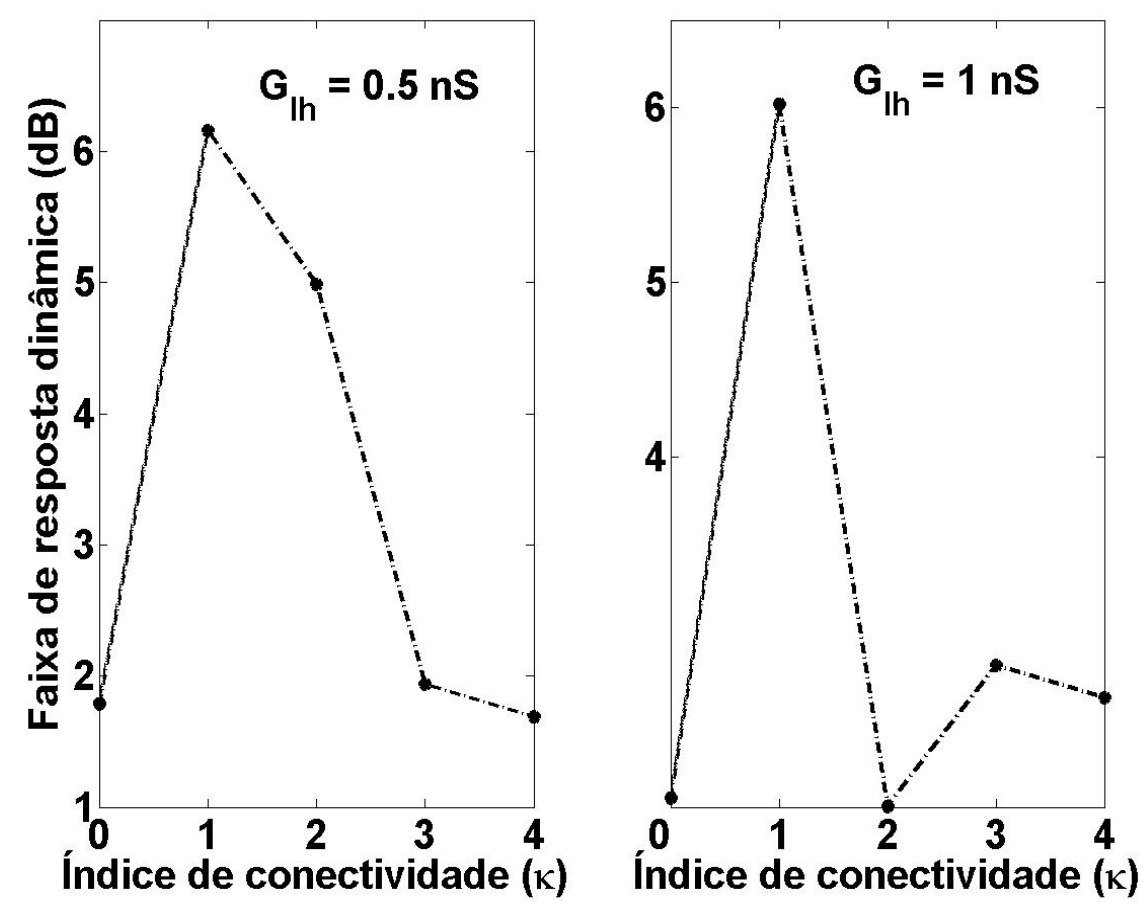

Figura 19. Faixa dinâmica da rede de células bipolares em função do índice de conectividade da rede de bastonetes. Cada figura indica a faixa dinâmica medida nas células bipolares quando a condutância do canal $I_{h}$ dos bastonetes assume $o$ valor indicado em cada gráfico.

Para testar a hipótese de que o alto grau de convergência da camada receptora para a camada de células bipolares juntamente com um grande número de bastonetes ativados pode provocar a saturação dos receptores sinápticos nas células bipolares, a inclinação da curva de saturação da sinapse química entre as células das duas camadas foi modificada pela alteração do parâmetro $V_{\text {slope }}$ da equação 18 . Especificamente, as mesmas simulações descritas acima foram refeitas com o valor de $V_{\text {slope }}$ alterado para 20 $\mathrm{mV}$, correspondendo a uma redução na inclinação da curva. Os novos resultados estão mostrados no diagrama da figura 20.

Comparando as linhas e colunas dos diagramas das figuras 18 e 20, pode-se observar que houve uma alteração nos máximos da faixa dinâmica. Com a redução no ganho (inclinação) da curva de saturação da sinapse, mais receptores são ativados sem provocar uma saturação antecipada na camada de células bipolares. Dessa forma, os picos da faixa dinâmica foram deslocados para a faixa onde o acoplamento é crítico, ou seja, $\kappa=2$. 


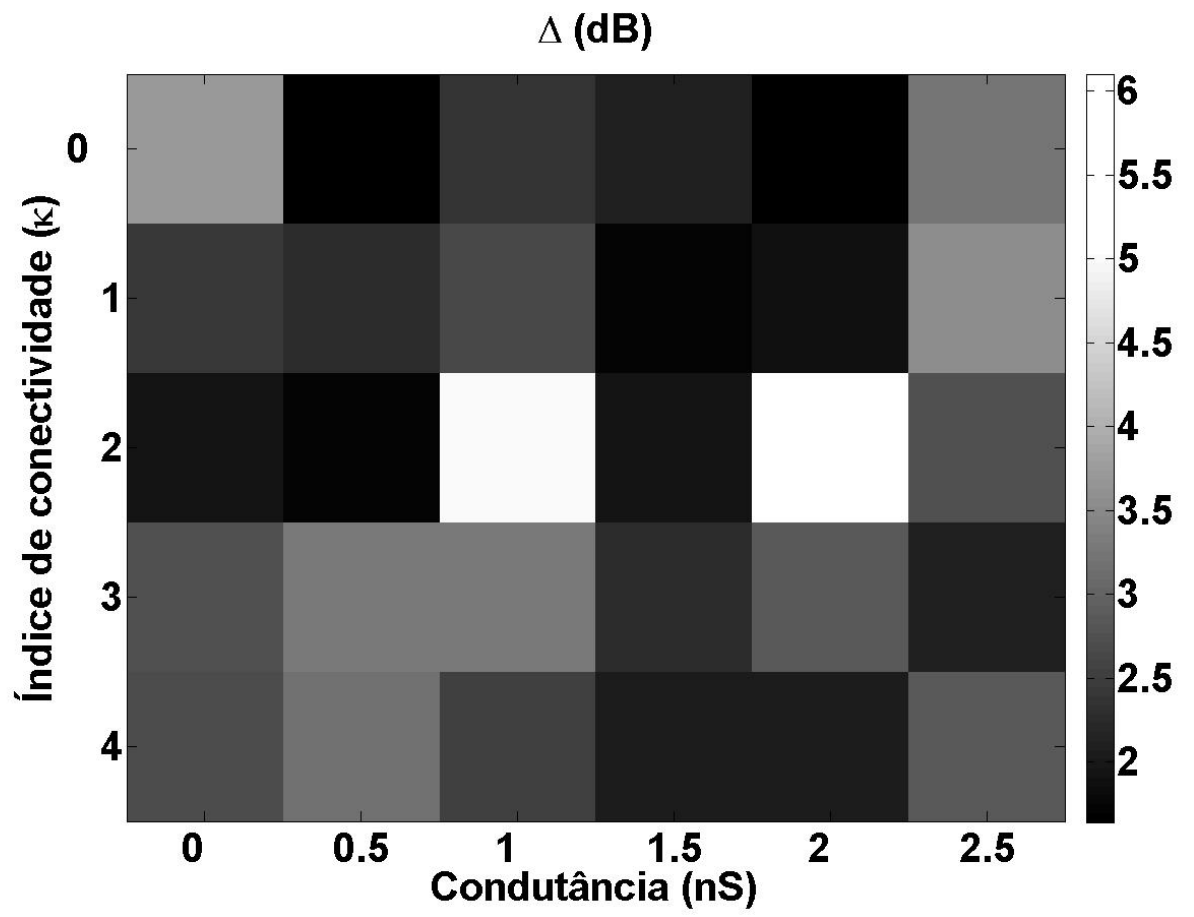

Figura 20. Faixa dinâmica da rede de células bipolares que recebe sinapses químicas com ganho reduzido dos bastonetes, em função do índice de conectividade da rede de bastonetes e da condutância do canal $\mathrm{I}_{\mathrm{h}}$ dos bastonetes. Para todas as combinações de parâmetros do diagrama, foi utilizado $V_{\text {slope }}=20$ mV na equação 18.

Diferentemente do observado na camada de bastonetes, a camada de células bipolares possui um comportamento semelhante ao de um filtro passa-alta para a faixa dinâmica, privilegiando os sinais que produzem uma faixa dinâmica máxima, conforme destacado nos diagramas das figuras 18 e 20.

A redução na inclinação da curva de saturação da sinapse química entre um bastonete e uma célula bipolar permitiu a obtenção de um máximo da faixa dinâmica quando $g_{\text {ih }}=2 \mathrm{nS}$ e $\kappa=2$. Esse resultado está de acordo com as evidências obtidas no experimento I de que um alto valor de condutância do canal $I_{h}$ reduz a amplitude de resposta do bastonete, evitando uma saturação antecipada e contribuindo para aumentar a faixa dinâmica das células bipolares. 
Estudo computacional sobre a influência de sinapses elétricas entre bastonetes na faixa dinâmica escotópica da retina de vertebrados

\section{Experimento IV: Circuito primário e secundário da retina}

Para as simulações relativas a este experimento utilizou-se a rede completa com os dois circuitos de processamento de sinas escotópicos descritos no capítulo anterior. $\mathrm{O}$ objetivo foi explorar o efeito dos diferentes padrões de conectividade nas camadas da retina que possuem sinapses elétricas e do canal ativado pela hiperpolarização dos bastonetes sobre a faixa dinâmica da única célula ganglionar do modelo, representando a saída da rede.

Em todas as simulações somente os bastonetes recebem o estímulo, simulando assim a visão periférica responsável pelo processamento de sinais escotópicos. Para isso, foi utilizado o mesmo padrão de estímulo descrito anteriormente, onde o número de bastonetes que efetivamente absorvem o estímulo está entre $25 \%$ e $50 \%$ do total de receptores, aleatoriamente selecionados.

No primeiro conjunto de simulações considerando o modelo completo da retina, apenas a condutância do canal $\mathrm{I}_{\mathrm{h}}$ nos bastonetes e o valor do índice de conectividade $\kappa$ na camada receptora foram alterados. Para todos os resultados a seguir, $\kappa$ se refere ao padrão de conexão utilizado para o acoplamento elétrico entre dois receptores, sejam eles cones ou bastonetes. A mesma faixa de valores para a condutância do canal $I_{h}$ utilizada nos experimentos anteriores foi utilizada neste caso. Os resultados das simulações, variando-se apenas o valor de $\kappa$ na camada receptora e fixando em $\kappa=2 \mathrm{o}$ índice de conectividade entre as células amácrinas AII, são apresentados no diagrama da figura 21. Nas simulações que resultaram neste diagrama, a intensidade do acoplamento elétrico entre as células amácrinas AII e entre células amácrinas AII e bipolares dos cones é igual a $5000 \mathrm{M} \Omega$ (SMITH \& VARDI, 1995).

Assim como no caso da rede composta apenas por bastonetes e células bipolares, valores máximos da faixa dinâmica da rede completa ocorrem quando os receptores estão acoplados com um índice de conectividade subcrítico igual a 1. Os valores para a condutância do canal $I_{h}$ correspondentes aos picos na faixa dinâmica, porém, são maiores que os do caso anterior, mas ainda são compatíveis com valores reportados na literatura (MAO et al., 2003; LIU \& KOURENNYI., 2004).

Esse resultado sugere que, à medida que novos estágios de processamento de informação são adicionados à retina, deve ocorrer um reajuste dos parâmetros intrínsecos dos bastonetes (condutância do canal $\mathrm{I}_{\mathrm{h}}$ ) para manter a faixa dinâmica da 
última camada no máximo. Um reajuste no índice de conectividade $\kappa$ também seria possível teoricamente, mas os resultados mostram que a mudança de $\kappa=1$ para $\kappa=2$ reduz a faixa dinâmica para todos os valores de $\mathrm{g}_{\text {ih }}$. Isto talvez seja assim porque o impacto do aumento no índice de conectividade sobre a saturação das sinapses feitas pelos receptores deve ser maior que o impacto do aumento em $g_{\text {ih }}$. Conforme mostrado na figura 13, aumentos em $\mathrm{g}_{\text {ih }}$ têm efeitos pequenos sobre o pico do potencial de membrana do bastonete.

Além do suporte às evidências das simulações anteriores de que o máximo da faixa dinâmica escotópica da retina ocorre para um valor subcrítico de conectividade entre os fotorreceptores, outro resultado importante pode ser observado na figura 21. Quando $\kappa=0$ não existe acoplamento elétrico entre os receptores, o que significa que o circuito secundário representado na figura 5 está desativado e que o circuito primário só está ativado pelas sinapses químicas entre os bastonetes e as células bipolares dos bastonetes. A redução na faixa dinâmica neste caso é superior a $40 \%$ quando comparada ao valor máximo para $\kappa=1$ (figura 25 , esquerda). Isto significa que o acoplamento elétrico entre receptores é o principal fator responsável pelo aumento na faixa dinâmica da retina. Um grau de acoplamento muito grande, porém, com $\kappa>1$, implica em um aumento subótimo da faixa dinâmica, sendo que o valor ótimo da faixa dinâmica ocorre para o caso do acoplamento subcrítico com $\kappa=1$.

Considerando apenas o conjunto de parâmetros que produz o pico na faixa de reposta dinâmica da rede $\left(\mathrm{g}_{\mathrm{ih}}=2,5 \mathrm{nS}\right.$ e $\left.\kappa=1\right)$, pode-se observar o comportamento da célula ganglionar por sua curva $f x i$ mostrada na figura 22. A curva desta figura não possui qualquer região plana, que poderia indicar uma saturação antecipada. Pelo contrário, a curva possui uma inclinação praticamente constante, indicando um início de saturação por volta de 40 pA. Esse comportamento é bastante semelhante ao observado em célula ganglionares do tipo $\mathrm{ON}$ na retina de camundongos quando as células receptoras absorvem estímulos luminosos (DEANS et al., 2002). 
Estudo computacional sobre a influência de sinapses elétricas entre bastonetes na faixa dinâmica escotópica da retina de vertebrados

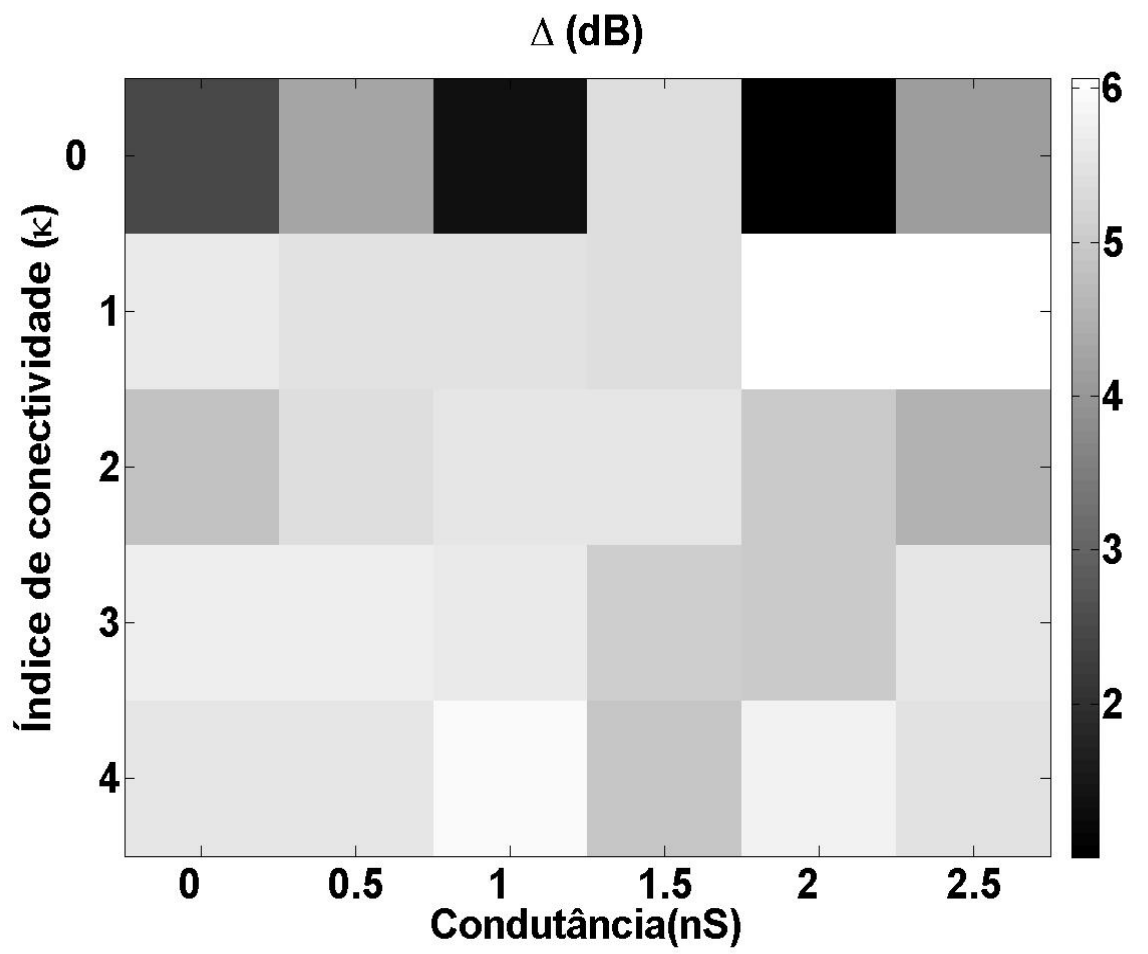

Figura 21. Faixa dinâmica da célula ganglionar do modelo de retina em função do índice de conectividade da camada receptora e da condutância do canal $\mathrm{I}_{\mathrm{h}}$ dos bastonetes. Neste caso, o índice de conectividade da camada de células amácrinas AII foi fixado em $\mathrm{k}=2$.

O comportamento dos potenciais de ação da célula ganglionar para esse conjunto ótimo de parâmetros, $\mathrm{g}_{\mathrm{ih}}=2.5 \mathrm{nS}$ e $\kappa=1$, pode ser estudado com o auxílio de um diagrama de fase semelhante ao mostrado na figura 10. Esse diagrama de fase para a célula ganglionar foi construído e está mostrado na figura 23. O diagrama construído permite observar que a forma das curvas é bastante similar para cada uma das amplitudes de estímulo utilizadas, indicando que a forma dos potenciais de ação é conservada para toda a faixa de estímulos, apesar da alteração na freqüência de disparos. Além disso, as curvas são bastante semelhantes às apresentadas na figura 10, apesar do aumento da corrente total na célula ganglionar representada no eixo y pela relação Volts/segundo. A semelhança entre as figuras 10 e 23 indica que as diferentes configurações da rede interferem na faixa de resposta dinâmica sem alterar a forma dos potenciais de ação, comparados com a resposta produzida pelo modelo de célula ganglionar isolada (figura 9). 


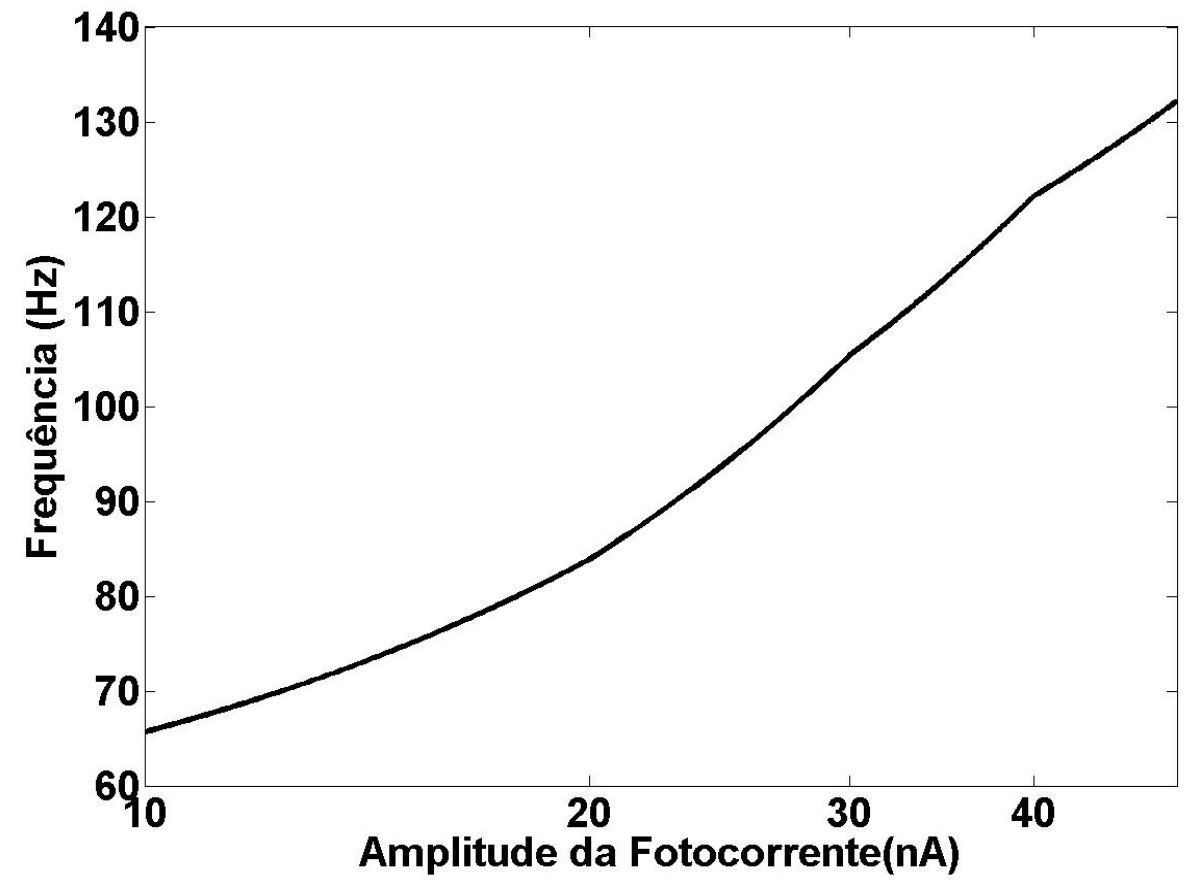

Figura 22. Freqüência de disparos da célula ganglionar em função da amplitude do estímulo na camada receptora em escala linear-log. Curva teórica obtida para o modelo completo de retina com $g_{i h}=2.5 \mathrm{nS}$ e $\mathrm{K}=1$.

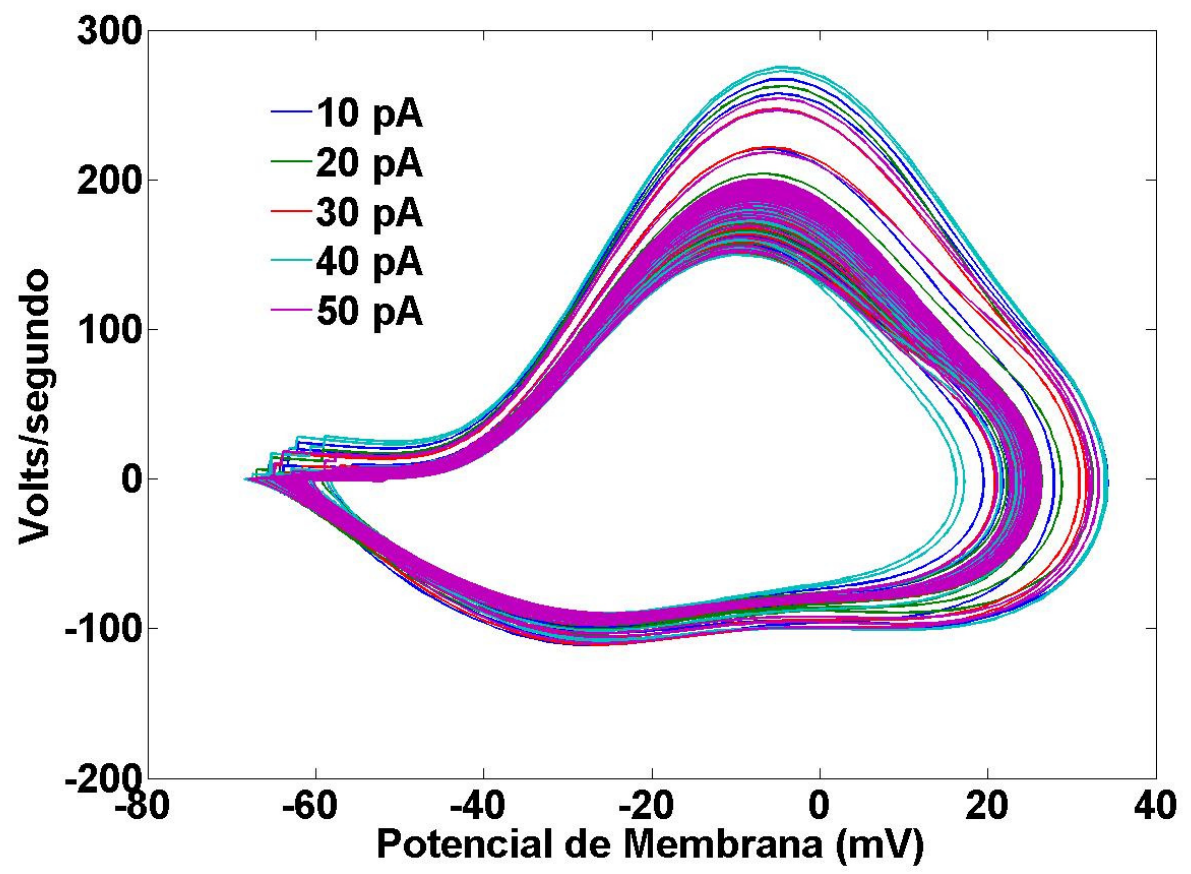

Figura 23. Diagrama de fase da célula ganglionar para os cinco valores de amplitude do estímulo indicados na figura. Cada cor representa a resposta medida na célula ganglionar para uma determinada amplitude de estímulo. Todas as curvas foram obtidas considerando o modelo completo de retina com $g_{\text {ih }}$ $=2 n S$ e $\mathrm{K}=1$. 
Estudo computacional sobre a influência de sinapses elétricas entre bastonetes na faixa dinâmica escotópica da retina de vertebrados

Para explorar os efeitos do índice de conectividade entre as células amácrinas, um segundo conjunto de simulações foi executado com o modelo completo. Desta vez, apenas o índice $\kappa$ da camada de células AII foi variado, fixando-se em $\kappa=2$ o índice de conectividade entre as células receptoras. Os resultados deste novo conjunto de simulações são apresentados na figura 24, dando a faixa dinâmica da célula ganglionar em função do índice $\kappa$ da camada de células AII e da condutância do canal $I_{h}$ dos bastonetes. É possível observar que, diferentemente do observado nas simulações anteriores, não existe nenhum valor acima de $6 \mathrm{~dB}$ para a faixa de resposta dinâmica, com a faixa dinâmica variando numa estreita faixa entre 4,5 e 5,9 dB. Isto é uma conseqüência do fato de se usar o valor $\kappa=2$ para o índice de conectividade entre as células receptoras, pois, como visto no experimento anterior, este valor de $\kappa$ não fornece o máximo da faixa dinâmica da célula ganglionar.

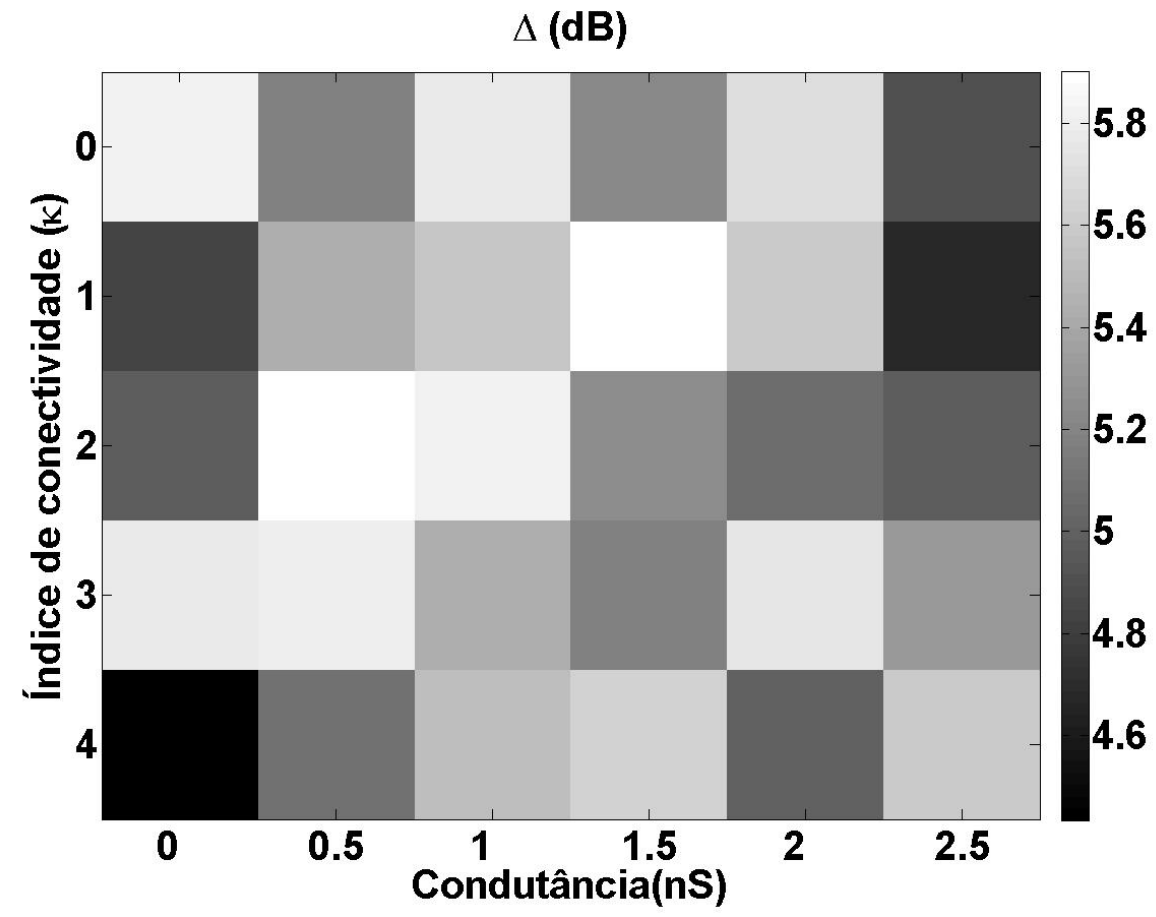

Figura 24. Faixa dinâmica do modelo de célula ganglionar da retina em função do índice de conectividade da camada de células amácrinas AII e da condutância do canal $\mathrm{I}_{\mathrm{h}}$ dos bastonetes. Neste caso, o índice de conectividade na camada de células receptoras foi fixado em $K=2$.

A idéia de se usar esse valor subótimo de $\kappa$ para as células receptoras era testar se alterações no nível de acoplamento entre as células amácrinas poderiam ter um papel compensatório neste caso, que é o caso crítico do ponto de vista da conectividade da rede de receptores, otimizando a faixa dinâmica. Os resultados, porém, indicam que isso 
não ocorre e o fato de $\kappa$ ser igual a 2 para a camada de fotorreceptores impede que a faixa dinâmica seja máxima (isto é, acima de $6 \mathrm{~dB}$ ), independentemente do valor de $\kappa$ para as células amácrinas e da condutância do canal $\mathrm{I}_{\mathrm{h}}$ dos bastonetes.

Assim como feito no primeiro conjunto de simulações deste experimento, a variação percentual da faixa dinâmica em relação ao seu máximo foi calculada para cada um dos valores de índice de conectividade da camada de células amácrinas AII e o resultado está mostrado a figura 25 (direita). A variação percentual $(\delta)$ da faixa dinâmica foi definida como:

$$
\delta=\frac{\Delta_{\max }-\Delta_{m}}{\Delta_{\max }}
$$

onde $\Delta_{\max }$ é o valor máximo da faixa dinâmica obtido entre as médias $\Delta_{m}$. Os valores de $\Delta_{m}$ foram calculados pelas médias aritméticas dos valores da faixa dinâmica para cada linha dos diagramas representados nas figuras 21 e 24 . Desta forma, ao se tomar a média da faixa dinâmica para os diferentes valores de $g_{\text {ih }}$ é possível analisar isoladamente o papel do índice de conectividade na amplificação ou redução dessa faixa.
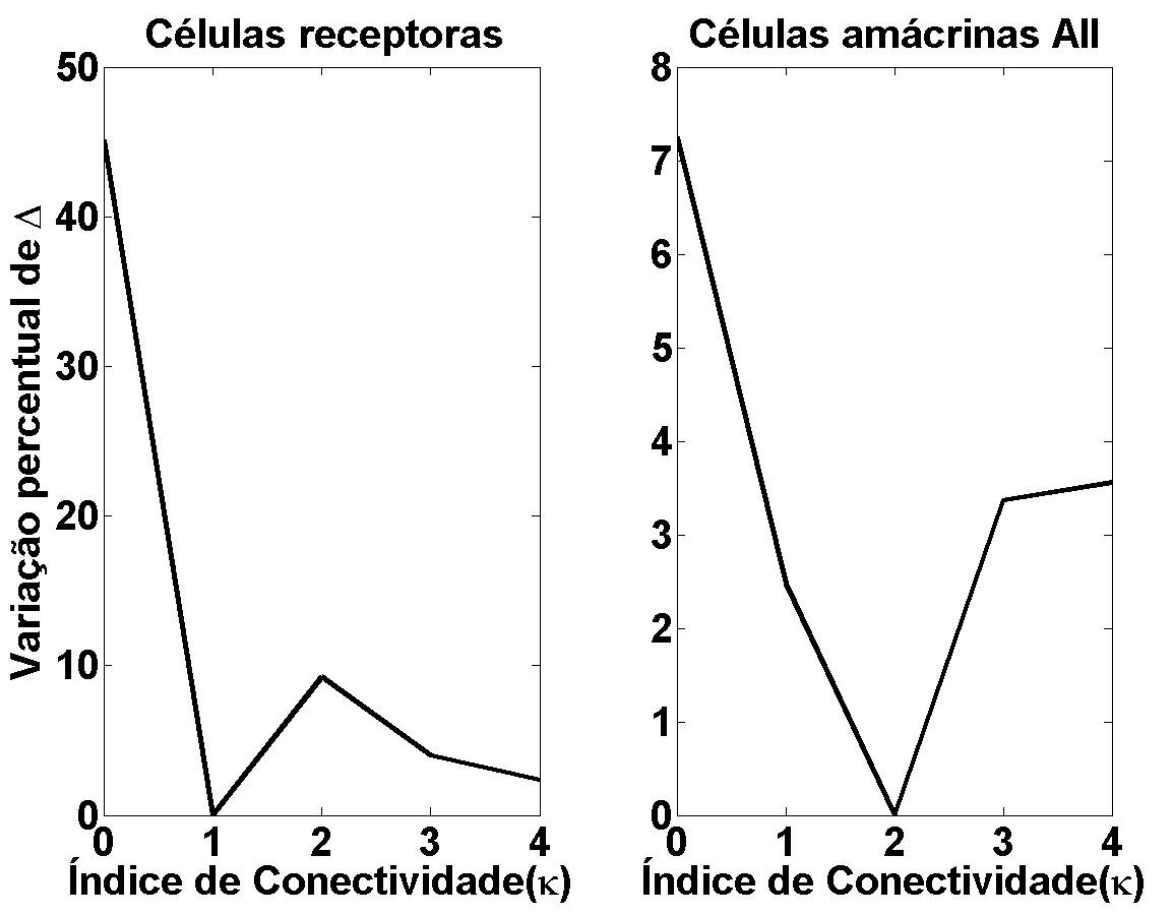

Figura 25. Variação percentual da faixa dinâmica em relação ao seu máximo valor em função do índice de conectividade, para diferentes camadas do modelo. A figura à esquerda representa os resultados obtidos através da média calculada para cada uma das linhas do diagrama da figura 21. A figura à direita representa os resultados obtidos para cada uma das linhas do diagrama da figura 24. 
Estudo computacional sobre a influência de sinapses elétricas entre bastonetes na faixa dinâmica escotópica da retina de vertebrados

Nos resultados apresentados na figura 25, a variação percentual na faixa dinâmica é muito maior quando se altera o índice de conectividade da camada receptora do que quando se altera o índice de conectividade da camada de células amácrinas AII. Este resultado sugere que o acoplamento elétrico na camada receptora possui um papel importante na amplificação da faixa dinâmica, enquanto que a presença de sinapses elétricas entre as células amácrinas possui um papel secundário na amplificação dessa faixa. O acoplamento elétrico entre células amácrinas pode estar mais relacionado com outros fenômenos, como, por exemplo, o mecanismo de seletividade direcional das células ganglionares (FRIED et al., 2003). 


\section{Capítulo VI}

\section{Discussão dos resultados e aproximações do modelo}

Neste capítulo são discutidos os principais resultados obtidos em cada um dos quatro experimentos realizados bem como as principais aproximações e limitações do modelo. Além disso, a relevância dos resultados é analisada através das predições que o modelo pode realizar. Possíveis experimentos futuros são sugeridos, uma vez que o grande número de detalhes biológicos do modelo permite o estudo de diversos mecanismos de processamento de sinais na retina de vertebrados.

\section{Discussão dos resultados}

Conforme descrito anteriormente em outros trabalhos experimentais e teóricos (BAYLOR et al., 1984, KAMIYAMA et al., 1996, PUBLIO et al., 2006), a presença da da corrente $I_{h}$ nos bastonetes da retina de vertebrados altera de forma significativa $o$ pico de resposta deste receptor, reduzindo sua amplitude máxima conforme o valor da condutância $g_{\text {ih }}$ aumenta (figura 13). No experimento $\mathrm{I}$, o bloqueio da corrente $\mathrm{I}_{\mathrm{h}}$ reduziu a faixa de resposta dinâmica do modelo do bastonete isolado. Este resultado se torna ainda mais relevante quando analisado em conjunto com os resultados obtidos com a rede acoplada e nas camadas posteriores.

No segundo experimento, foi possível observar que o canal $I_{h}$ possui um papel modulatório na faixa dinâmica medida na camada de bastonetes. Diferentemente do observado em trabalhos teóricos (COPELLI et al., 2005, KINOUCHI \& COPELLI, 2006) com uma rede bidimensional de elementos excitáveis, a faixa dinâmica não é maximizada apenas na criticalidade. Dependendo da condutância do canal $\mathrm{I}_{\mathrm{h}}$, a faixa dinâmica da rede de bastonetes é maximizada para um índice de conectividade critico ou subcrítico.

Quando se consideram mais camadas no modelo, como nos casos dos experimentos III (redes de bastonetes e de células bipolares dos bastonetes) e IV (modelo completo), a condutância do canal $I_{h}$ já não possui um efeito tão forte sobre a rede a ponto de permitir, para diferentes valores de $\mathrm{g}_{\mathrm{ih}}$, índices de conectividade entre os bastonetes 
Estudo computacional sobre a influência de sinapses elétricas entre bastonetes na faixa dinâmica escotópica da retina de vertebrados

tanto crítico como subcrítico capazes de produzir máximos na faixa dinâmica. Em tais casos, apenas o índice subcrítico $(\kappa=1)$ produz o máximo da faixa dinâmica.

Comparado os resultados dos experimentos III e IV com os obtidos no experimento II, onde a redução da condutância $g_{\text {in }}$ permitiu a obtenção da faixa dinâmica máxima na criticalidade, os resultados referentes às camadas posteriores mostram que a alta convergência existente entre as camadas faz com que uma redução no valor de $\mathrm{g}_{\text {ih }}$ provoque uma saturação antecipada das sinapses para índices de conectividade maiores que um, reduzindo a faixa dinâmica da rede.

Desta forma, o efeito modulatório do canal $\mathrm{I}_{\mathrm{h}}$ só é relevante quando se considera a rede de bastonetes isolada do resto da retina, desprezando-se sua conexão com outras camadas com altos fatores de convergência. Por este motivo, somente na camada receptora foi possível uma maximização da faixa dinâmica na criticalidade. Os resultados obtidos neste trabalho sugerem que em sistemas com múltiplas camadas a obtenção de uma faixa dinâmica máxima acontece somente para índices de conectividade subcríticos, devido a alta convergência entre as camadas e à necessidade de se evitar a saturação durante os primeiros estágios do processamento dos estímulos sensoriais.

Considerando a variação do padrão de conectividade por sinapses elétricas na camada receptora e na camada de células amácrinas, observa-se que, devido à alta convergência entre bastonetes e células bipolares, a variação percentual na faixa dinâmica é aproximadamente 5 vezes maior quando se varia o índice de conectividade na camada receptora do que quando se varia o índice de conectividade na camada de células amácrinas. Isto sugere que o acoplamento elétrico entre as células amácrinas não tem um efeito muito importante sobre a faixa dinâmica das células ganglionares da retina.

Ainda não há um estudo teórico sobre o efeito do acoplamento elétrico entre elementos excitáveis em um sistema composto por mais de uma camada desses elementos, similar ao feito por Kinouchi \& Copelli (2006) para uma única camada. Desta forma, o resultado obtido com este trabalho experimental (in silico) fornece uma previsão sobre o que deve ocorre neste caso: a faixa dinâmica da camada de saída é maximizada para um valor subcrítico de acoplamento entre os elementos da camada receptora. 


\section{Aproximações e Limitações do modelo}

Neste trabalho, um modelo biologicamente plausível da retina de vertebrados foi construído, incorporando os principais circuitos responsáveis pela transmissão de sinais de baixa intensidade luminosa. Uma grande quantidade de detalhes biológicos foi incluída no modelo, tanto referente aos mecanismos intracelulares como referente à arquitetura da rede. Os circuitos primário e secundário responsáveis pela visão periférica, mediados pelos bastonetes, foram incluídos após a construção dos modelos dos neurônios individuais que compõem ambos os circuitos (STERLING et al., 1988 ; DEANS et al., 2002).

A motivação principal para a construção de um modelo com um grande número de características biológicas, foi o de se investigar os mecanismos utilizados pela retina que permitem aos vertebrados se adaptar a condições tão distintas de luminosidade, com estímulos variando por um fator de $10^{10}$ (STERLING, 1998). Grande parte desses mecanismos não poderiam ser investigados com a construção de modelos mais abstratos, que não levassem em consideração a dinâmica de cada canal iônico presente nos neurônios da retina. Apesar de não se ter conhecimento de um modelo disponível na literatura com tantas características biológicas incorporadas, existem várias aproximações consideradas na construção. As principais aproximações e limitações decorridas disso são apresentadas a seguir.

Uma das aproximações mais importantes feitas neste modelo se refere ao processo de transdução da luz que ocorre nos segmentos externos de cones e bastonetes. A principal conseqüência da fototransdução nos receptores é a supressão transiente da corrente que existe entre os segmentos externo e interno de cones e bastonetes. Um modelo realista para o processo de fototransdução deve englobar os processos bioquímicos que resultam no fechamento dos canais dependentes de guanosina monofosfato cíclico (GMPc) no segmento externo dos receptores, dando origem à supressão transiente da corrente mencionada anteriormente (PUGH \& LAMB, 2000). A simulação deste processo, porém, acarretaria em um custo computacional muito alto para a quantidade de células receptoras utilizadas no modelo.

A fotocorrente, descrita em detalhes no capítulo II exibe várias características bem conhecidas, como o crescimento monotônico de sua amplitude em função da intensidade do flash e um pico na amplitude por volta de 1s (PUGH \& LAMB, 2000 ; LIU \& KOURENNYI., 2004). Tendo em vista a restrição computacional e o grande 
Estudo computacional sobre a influência de sinapses elétricas entre bastonetes na faixa dinâmica escotópica da retina de vertebrados

número de informações disponíveis sobre a fotocorrente, neste trabalho apenas o produto final da transdução foi modelado e utilizado como estímulo da rede. A vantagem dessa abordagem é permitir a utilização de uma rede em larga escala que reproduza os critérios de convergência observados experimentalmente (STERLING et al., 1988). A principal restrição provocada pela utilização de um modelo de fotocorrente ao invés de um modelo completo de transdução (KAMIYAMA et al., 1996) está relacionada à saturação observada experimentalmente na fotocorrente em resposta a estímulos de intensidades superiores a 40 ou 50 pA (JONES, 1995 ; PUGH \& LAMB, 2000). Não existe no modelo nenhum mecanismo de saturação dos bastonetes em resposta a estímulos de amplitudes superiores a 50 pA. Para contornar essa limitação, apenas estímulos cujas amplitudes estão na faixa de 10 a 50 pA foram utilizados em todas as simulações.

Os terminais sinápticos de cones, bastonetes e células bipolares da retina de vertebrados possuem uma conexão especializada chamada de sinapse ribbon. Esse tipo de sinapse é utilizada para a transmissão de sinais analógicos, ou seja, é responsável pela transmissão de sinais nas células da retina que não disparam potenciais de ação. Devido à grande presença de vesículas sinápticas, esse tipo de sinapse permite a liberação contínua de glutamato nos terminais de receptores e células bipolares (SIKORA et al., 2005). O modelo disponível na literatura para essa sinapse é complexo em detalhes, simulando inclusive a difusão do neurotransmissor na fenda sináptica (SIKORA et al., 2005). Este modelo foi testado inicialmente nas simulações, mas o elevado custo computacional necessário para a implementação de cada sinapse inviabilizou sua inclusão no modelo final.

Neste trabalho um modelo bastante simplificado de sinapse analógica foi utilizado, incorporando um mecanismo de saturação artificial (BRIAM, 2003). A utilização de um modelo mais simplificado é vantajosa por ser viável sua utilização em uma rede onde a convergência entre bastonetes e células bipolares é muito alta. Em contrapartida, o modelo simplificado não possui uma liberação de neurotransmissores dependente da concentração interna de cálcio, um fator que pode ser determinante no comportamento da sinapse (SIKORA et al., 2005). Além disso, recentes trabalhos mostram que sob condições de baixa luminosidade um mecanismo de depressão sináptica nas sinapses ribbon entre células bipolares e amácrinas pode contribuir para o aumento da faixa dinâmica da retina (DUNN \& RIEKE, 2008). Um possibilidade é a de que os futuros 
experimentos envolvendo o modelo de retina proposto neste trabalho possam incluir um mecanismo sináptico dependente da concentração interna de cálcio com baixo custo computacional, incorporando mais uma característica biológica ao modelo.

Outra aproximação do modelo é a utilização de modelos de neurônios com um único compartimento elétrico ao invés de modelos com uma reconstrução morfológica mais realística. Um fator determinante para a utilização desta abordagem foi a falta de dados sobre a reconstrução morfológica das células que participam dos circuitos primário e secundário mediados pelos bastonetes. Foram encontradas na literatura apenas as informações necessárias para a reconstrução morfológica de diversos tipos de células ganglionares (FOHLMEISTER \& SHEASBY, 1999) e alguns tipo de células amácrinas que não participam dos circuitos primário e secundário (FRIED et al., 2003). Se, por um lado, a utilização de modelos com um único compartimento reduz o custo computacional, o modelo não pode simular processos que só ocorrem em árvores dendríticas complexas, como as presentes em células amácrinas e ganglionares (FOHLMEISTER \& SHEASBY, 1999 ; FRIED et al., 2003).

Como o objetivo principal do trabalho é o de investigar o papel dos mecanismos intracelulares e das sinapses elétricas na amplificação da faixa dinâmica da retina, a utilização dos modelos simplificados não compromete os resultados obtidos. As células bipolares, os cones e os bastonetes possuem uma morfologia bastante simples, que pode ser facilmente aproximada por um único compartimento (STERLING, 1998). Já as células amácrinas e ganglionares necessitariam de uma morfologia mais realista se um dos objetivos do trabalho fosse relacionado, por exemplo, com uma investigação dos mecanismos responsáveis pela seletividade direcional nas células ganglionares (FRIED et al., 2003).

\section{Comentários finais e possíveis experimentos futuros}

A construção de um modelo de retina com múltiplas camadas e diversas características biológicas incorporadas possibilita a realização de futuros experimentos, utilizando como base os resultados e parâmetros obtidos neste trabalho, visando o melhor entendimento de fenômenos que ainda não foram muito bem explorados. Todos os modelos de neurônios utilizados neste trabalho possuem modelos de canais iônicos construídos com base nos dados experimentais disponíveis na literatura. Além disso, a 
Estudo computacional sobre a influência de sinapses elétricas entre bastonetes na faixa dinâmica escotópica da retina de vertebrados

construção de um modelo de rede que incorpora os principais critérios de convergência e divergência observados experimentalmente (STERLING, 1998) possibilita uma ampla investigação de mecanismos intracelulares e da rede através de um ajuste de parâmetros mais refinado e de bloqueios de canais iônicos e sinapses. Este nível de modelagem permite ainda a realização de experimentos de difícil execução em neurônios reais, possibilitando predições a partir de um conjunto de simulações.

Um experimento adicional que poderia ser realizado para testar a estabilidade do modelo seria o de realizar um busca mais fina de parâmetros, utilizando passos menores para os valores de condutância do canal $\mathrm{I}_{\mathrm{h}}$, para encontrar um valor que também maximize a faixa de resposta dinâmica mas que seja mais próximo ao encontrado em outros trabalhos (KAMIYAMA et al., 1996 ; MAO et al., 2003 ; LIU \& KOURENNYI., 2004).

Dada a semelhança entre a estrutura do modelo e a retina de vertebrados, ambos compostos pelas camadas paralelas de receptores, células bipolares, células amácrinas e ganglionares realizando conexões laterais e diretas, um fenômeno que pode ser investigado futuramente é o atraso na percepção de objetos. Esse atraso na percepção é conhecido na literatura como flash-lag, e acontece quando o observador compara as posições de um objeto em movimento e um flash estacionário, ambos apresentados simultaneamente (BALDO \& CATICHA, 2005). Nesses casos, o observador tem a percepção de que o objeto em movimento se encontra a frente do objeto estacionário, apesar de ambos terem sido apresentados lado a lado. Para a investigação desse fenômeno no modelo proposto neste trabalho seria necessário apenas o reescalonamento da rede seguindo os padrões de convergência para uma determinada excentricidade. Esse reescalonamento se faz necessário, pois o modelo precisa de um número maior de células ganglionares para que se meça a diferença entre as posições em que o estímulo é aplicado e a resposta da rede é obtida.

Um tipo específico de célula ganglionar apresenta um mecanismo de seletividade direcional, ou seja, respondendo com uma alta freqüência para estímulos que se movimentam na sua direção preferencial e respondendo com baixas freqüências a estímulos que se movem na direção oposta, ou nula (BARLOW et al., 1964). Esse tipo de célula ganglionar realiza um acoplamento indireto com as células vizinhas mediado por sinapses elétricas feitas com um subtipo de célula amácrina (XIN \& BLOOMFIELD, 1997). Recentes resultados experimentais mostram que pares desse 
tipo de célula ganglionar apresentam sincronia de resposta quando a retina é submetida a estímulos em todas as direções, com exceção da direção nula (ACKERT et al., 2006). Quando o estímulo se move na direção nula, a sincronia entres os pares é desfeita devido à presença de sinapses inibitórias entre células amácrinas e ganglionares deste tipo.

Esse mecanismo de sincronia em células ganglionares que apresentam seletividade direcional, poderia ser investigado no modelo proposto neste trabalho com a adição de mais algumas células ganglionares e um modelo mais realístico de célula amácrina. $O$ objetivo de um estudo desse tipo seria o de investigar quais mecanismos estão envolvidos na seletividade direcional observada nas células ganglionares e na sincronia de resposta em pares dessas células. Recentes evidências mostram que o mecanismo de seletividade direcional observado em um tipo de célula ganglionar pode surgir já na camada de células amácrinas do tipo ON-OFF (MILLER et al., 2006). A influência de cada um desses mecanismos na seletividade direcional pode ser investigada no modelo de retina proposto neste trabalho, após pequenas alterações na camada de células amácrinas e no padrão de estimulação utilizado na rede. 
Estudo computacional sobre a influência de sinapses elétricas entre bastonetes na faixa dinâmica escotópica da retina de vertebrados

\section{Capítulo VI}

\section{Conclusão}

Este estudo computacional teve como objetivo principal uma investigação sobre os mecanismos responsáveis pela amplificação da faixa dinâmica na retina de vertebrados. Especificamente, foram analisados o papel das sinapses elétricas presentes nas primeiras etapas do processamento visual periférico e o papel da condutância do canal $\mathrm{I}_{\mathrm{h}}$ dos bastonetes. A segregação do sinal em diversas vias convergindo para as células ganglionares e a presença de sinapses elétricas entre os neurônios receptores e entre células amácrinas foram simuladas no modelo segundo as principais evidências experimentais (DEANS et al., 2002; VOLGYI et al., 2004).

Os resultados obtidos nos primeiros experimentos deste trabalho estão de acordo com recentes trabalhos teóricos, que sugerem que o acoplamento por sinapses elétricas pode aumentar a faixa dinâmica de uma camada de neurônios acoplados, em comparação com a faixa dinâmica da rede desacoplada (COPELLI et al., 2002; COPELLI et al., 2005).

Pelos resultados obtidos no experimento II, observa-se que o acoplamento elétrico provoca uma amplificação máxima na faixa dinâmica quando estas estão acopladas segundo o índice de conectividade crítico $(\kappa=2$ para a rede quadrada, como é o caso do modelo) para que haja percolação de ligação (GRIMMETT, 1999). Este resultado é compatível com um recente estudo teórico que mostra que a faixa dinâmica de uma rede de elementos excitáveis é maximizada quando os elementos têm um índice crítico de acoplamento (KINOUCHI \& COPELLI, 2006).

Os resultados do terceiro e quarto experimentos mostram que para sistemas com múltiplas camadas de processamento, como é o caso da retina, a maximização da faixa dinâmica da camada de saída ocorre para um acoplamento subcrítico dos receptores da camada de entrada, com $\kappa=1$. Isto ocorre por causa da alta convergência que existe entre os bastonetes e as células bipolares.

No experimento III foi mostrado que essa alta convergência faz com que exista uma saturação antecipada na camada de células bipolares quando muitos bastonetes são excitados $(\kappa>1)$, reduzindo a faixa dinâmica da retina. Quando a sinapse química 
presente entre bastonetes e células bipolares é alterada, reduzindo-se a inclinação da sua curva de saturação, é possível obter um valor máximo para a faixa dinâmica (acima de 6 dB) quando $\kappa=2$.

Outras importantes conclusões do trabalho dizem respeito ao papel da condutância do canal $I_{h}$ dos bastonetes (um mecanismo intracelular) sobre a faixa dinâmica dos bastonetes e da retina e sobre como ela pode interagir com a conectividade da camada de bastonetes (um mecanismo de rede) para amplificar a faixa dinâmica da retina.

Os resultados mostram que altos valores da condutância do canal $\mathrm{I}_{\mathrm{h}}$ produzem uma redução no pico de resposta do bastonete isolado, evitando sua saturação antecipada das sinapses químicas e amplificando a faixa dinâmica da rede. Com relação à rede, a condutância do canal $I_{h}$ possui um papel modulatório sobre a faixa dinâmica dos bastonetes. Dependendo do valor dessa condutância, o valor do índice de conectividade dos bastonetes que produz o máximo da faixa de resposta dinâmica nesta camada crítico ou subcrítico. Porém, quando mais camadas são consideradas, como é o caso do modelo completo descrito no experimento IV, o efeito da condutância do canal $\mathrm{I}_{\mathrm{h}}$ dos bastonetes não tem o mesmo impacto, pois mesmo um forte aumento de $\mathrm{g}_{\text {ih }}$ não é capaz de fazer com que o acoplamento crítico entre os bastonetes produza o valor máximo da faixa dinâmica das células ganglionares.

Apesar desses resultados estarem de acordo com as previsões feitas sobre o efeito do canal $\mathrm{I}_{\mathrm{h}}$ sobre a faixa dinâmica por trabalhos experimentais e teóricos (BAYLOR et al., 1984 ; KAMIYAMA et al., 1996), um estudo mais detalhado no espaço de parâmetros necessita ser feito para se determinar o real papel deste canal na faixa dinâmica. É possível ainda que outros mecanismos intracelulares não investigados neste trabalho possam contribuir para uma amplificação da faixa dinâmica.

O modelo proposto possui uma grande quantidade de parâmetros que ainda não foram devidamente explorados, principalmente no que se refere aos mecanismos intracelulares presentes em cada um dos modelos de neurônios utilizados. Uma melhor investigação nesses parâmetros pode definir em quais configurações o modelo é capaz de reproduzir os mesmos resultados, ou se existem outras configurações da rede que permitem a obtenção de uma maior faixa dinâmica, considerando uma faixa de parâmetros biologicamente restrita.

Por enquanto, com base nos resultados deste trabalho, pode-se concluir que existe uma fina combinação de parâmetros celulares e de rede, como a condutância do canal $\mathrm{I}_{\mathrm{h}}$ 
Estudo computacional sobre a influência de sinapses elétricas entre bastonetes na faixa dinâmica escotópica da retina de vertebrados

e o índice de conectividade dos fotorreceptores por sinapses elétricas, que fornece o máximo da faixa dinâmica da retina. Além disso, pelo resultado da simulação com o modelo completo de retina, este trabalho prevê que o grau ótimo de acoplamento entre os bastonetes para maximizar a faixa dinâmica das células ganglionares é subcrítico. 


\section{Referências Bibliográficas}

ACKERT, J.M.; WU, H.S.; LEE, J.C.; ABRAMS, J.; HU, E.H.; PERLMAN, I.; BLOOMFIELD,

S.A. Light-Induced Changes in Spike Synchronization between Coupled ON Direction Selective Ganglion Cells in the Mammalian Retina. Journal of Neuroscience, v.26, p.42064215, 2006.

AWATRAMANI, G.B.; SLAUGHTER, M.M. Intensity-dependent, rapid activation of presynaptic metabotropic glutamate receptors at a central synapse. Journal of Neuroscience, v.21, p.741-749, 2001.

BALDO, M.V.C.; CATICHA,N. Computational neurobiology of the flash-lag effect. Vision Research, v.45, p.2620-2630, 2005.

BARLOW, H. B. Summation and inhibition in the frog's retina. Journal of Physiology, v.1191, p.69-88, 1953.

BARLOW, H.B.; HILL, R.M.; LEVICK, W.R. Retinal ganglion cells respondingselectively to direction and speed of image motion in the rabbit. Journal of Physiology, v.177, p.377- 407, 1964.

BARNES, S.; HILLE, B. Ionic channels of the inner segment of tiger salamander cone photoreceptors. Journal of General Physiology, v.94, p.719-743, 1989.

BAYLOR, D.A.; MATTHEWS, G.; NUNN, B.J.; JACK, J.B.; REDMAN, S.J.; SEGEV, I. Location and function of voltage-sensitive conductances in retinal rods of the salamander. Journal of Physilogy, v.354, p.203-223, 1984.

BEAR, M.F.; CONNORS, B.W.; PARADISO, M.A. NEUROCIÊNCIAS - Desvendando o sistema Nervoso. 2.ed. São Paulo, , 2002.

BEECH, D.J.; BARNES, S. Characterization of a voltage gated $\mathrm{K}+$ channel that accelerates the rod response to dim light. Neuron, v.3, p.573-581, 1989.

BENNETT, M.V. Gap junctions as electrical synapses. Journal of Neurocytology, v.266, P.349-366, 1997.

BENNETT, M.V. Electrical synapses, a personal perspective (or history). Brain Research Reviews, v.321, p.16-28, 2000.

BERTSON, A.; SMITH, R.G.; TAYLOR, W.R. Postsynaptic calcium feedback between rods and rod bipolar cells in the mouse retina. Visual Neuroscience, v.21, p.913-924, 2004.

BLOOMFIELD, S.A.; DACHEUX, R.F. Rod vision: pathways and processing in the mammalian retina. Progress in Retinal and Eye Research, v.203, p. 351-384, 2001. 
BOSS, R.; SCHNEIDER, H.; WASSLE, H. Voltage and transmitter gated currents of AII amacrine cells in a slice preparation of the rat retina. Journal of Neuroscience, v.13, p.2874-2888, 1993.

BRIAM, M. During Fictive Locomotion, Graded Synaptic Currents Drive Bursts of Impulses in Swimmeret Motor Neurons. Journal of Neuroscience, v.23, p.595-596, 2003.

CARNEVALE, N.T; HINES, M.L. The NEURON Book. 1.ed.. Cambridge, UK, , 2006.

COPELLI, M. Physics of Psychophysics: it is critical to sense. Cooperative Behavior in Neural Systems: Ninth Granada Lectures, v.887, p.13-20, 2007.

COPELli, M.; OLIVEIRA, R.F.; ROQUE, A.C.; KINOUCHI, O. Signal compression in the sensory periphery. Neurocomputing, v.65-66, p.691-696, 2005.

DACEY, D.M. Circuitry for color coding in the primate retina. Proceedings of the National Academy of Sciences, v.932, p. 582-588, 1996.

DACHEUX, R.F.; RAVIOLA, E. Light responses from one type of ON-OF amacrine cells in the rabbit retina. Journal of Neurophysiolgy, v.74, p.2460-2468, 1995.

DEANS, M.R.; VOLGYI, B.; GOODENOUGH, D.A.; BLOOMFIELD L.A.; PAUL D.A. Connexin36 is essential for transmission of rod-mediated visual signals in the mammalian retina. . Neuron, v.36, p, 703-712, 2002.

DESTEXHE, A.; CONTRERAS, D.; SEJNOWSKI, T.J.; STERIADE, M. A model of spindle rhythmicity in the isolated thalamic reticular nucleus. Journal of Neurophysiology, v.72, p.803-818, 1994.

DOWLING, J.E. The Retina: An Approachable Part of the Brain.. . Cambridge, , 1987.

DUDEL, J. Fisiologia geral dos órgão dos sentidos. In: SMITH, R. F., (Ed.). Fisiologia Sensorial. São Paulo, EDUSP, 1977. cap. 1, p.1-26.

DUNN, F.A.; RIEKE, F. Single-Photon Absortions Evoke Synaptic Depression in the Retina to Extended the Operational Range of Rod Vision. Neuron, v.57, 894-904, 2008.

ELIASOF, S.; BARNES, S.; WERBLIN, F. The interaction of ionic currents mediating single spike activity in retinal amacrine cells of the tiger salamander. Journal of Neuroscience, v.711, p.3512-3524, 1987.

FAMIGLIETTI, E.V.; KOLB, H. A bistratified amacrine cell and synaptic circuitry in the inner plexiform layer of the retina. Brain Research, v.841, p.293-300, 1975.

FOHLMEISTER, J.F.; MILLER, R.F. Impulse Encoding Mechanisms of Ganglion Cells in the Tiger Salamander Retina. Journal of Neurophysiology, v.78, p.1395-1947, 1997.

FOHLMEISTER, J.F.; SHEASBY, B.W. Impulse encoding across the dendritic morphologies of retinal ganglion cells. Journal of Neurophysiology, v.81, p.1685-1698, 1999. 
FREED, M.A.; SMITH, R.G.; STERLING, P. The rod bipolar array in cat retina: Pattern of input from rods and GABA-accumulating amacrine cells. Journal of Comparative Neurology, v.266, p.445-455, 1987.

FRIED, S.I.; MUNCH, T.A.; WERBLIN, F.S. Mechanisms and circuitry underlying directional selectivity in the retina. Journal of Neurophysiology, v.89, p. 2449-2458, 2003.

FURSHPAN, E.J.; POTTER,D.D. Transmission at the giant motor synapse of the crayfish. Journal of Physilogy, v.145, p.289- 325, 1959.

GRIMMETT, G. Percolation. 2. Berlin, Springer-Verlag, 1999.

HARTLINE, H. K. The response of single optic nerve fibers of the vertebrate eye to illumination of the retina. American Journal of Physiology, v.121, p.400-415, 1938.

HENNIG, M.; FUNKE, K.; WRGTTER, F. The Influence of Different Retinal Subcircuits on the Nonlinearity of Ganglion Cell Behavior. Journal of Neuroscience, v.2219, p.8726-8738, 2002.

HILLE, B. Ion Channels of Excitable Membranes. 3. ed. Sunderland, Sinauer, 2001.

HINES, M.L.;CARNEVALE, N.T. The NEURON simulation environment. Neural Computation, v.9, p.1179-1209, 1997.

HODGKIN, A. L.; HUXLEY, A. F. A quantitative description of membrane current and its application to conduction and excitation in nerve. Journal of Physiology, v.1174, p.500-544, 1952.

IZHIKEVICH, E. M. Dynamical systems in neuroscience: the geometry of excitability and bursting. 1.ed. London, MIT Press, .

JACOBS, G.H. The distribution and nature of colour vision among the mammals. Biological Reviews, v.683, p.413-471, 1993.

JACOBY, R.A.; WU,S.M. AMPA-preferring receptors mediate excitatory non-NMDA responses of primate retinal ganglion cells. Visual Neuroscience, v.18, p.703-710, 2001.

JONES, G.J. Light adaptation and the rising phase of the flash photocurrent of salamander retinal rods. Journal of Physiology, v.487, p.441-451, 1995.

KAMERMANS, M.; SPEKREIJSE, H. Spectral behavior of cone-driven horizontal cells in teleost retina. Progress in Retinal and Eye Research, v.141, p. 1-46, 1995.

KAMIYAMA, Y.; OGURA, T.; USUI S.; BLOOMFIELD L.A. Ionic current model of the vertebrate rod photoreceptor. Vision Research, v.36, p.4059-4068, 1996.

KANEDA, M.; KANEKO, A. Voltage-gated sodium currents in isolated retinal ganglion cells of the cat: relation between the inactivation kinetics and the cell type. Neuroscience Research, v.11, p.261-275, 1991. 
KANEKO, A. Physiological and morphological identification of horizontal, bipolar and amacrine cells in goldfish retina. Journal of Physiology, v.207, p.623-633, 1970.

KANEKO, A.; PINTO, L.H.; TACHIBANA, M. Transient Calcium current of retinal bipolar cells of the mouse. Journal of Physiology, v.410, p.613-629, 1989.

KANEKO, A.; TACHIBANA, M. A voltage-clamp analysis of membrane currents in solitary bipolar cells dissociated from carassius auratus.. Journal of Physiology, v.358, p.132-152, 1985.

KINOUCHI, O.; COPELLI, M. Optimal dynamical range of excitable networks at criticality. Nature Physics, v.2, p. 348-351, 2006.

KOCH, C. Biophysics of Computation. 1.ed. Oxford, Oxford University Press, 1999.

KOLB, H.; LINBERG, K.A., FISHER, S.K. Neurons of the human retina: a Golgi study. Journal of Comparative Neurology, v.3182, p. 147-87, 1992.

KOLB, H.; NELSON, R.; MARIANI, A. Amacrine, bipolar and ganglion cells of the cat retina: a Golgi study. Vision Research, v.217, p. 1081-1114, 1981.

KOURENNYI, D.E.; LIU, X.; BARNES, S. Modulation of Rod Photoreceptor Potassium Kx Current by Divalent Cations. Annals of Biomedical Engineering, v.30, p.1196-1203, 2002.

KOURENNYI, D.E.; LIU, X.D.; HART, J.; MAHMUD, F.; BALDRIDGE, W.H.; BARNES, S. Reciprocal modulation of calcium dynamics at rod and cone photoreceptor synapses by nitric oxide. Journal of Neurophysiology, v.92, p.477-483, 2004.

LETTVIN, J.Y.; MATURANA, H.R.; MCCULLOCH, W.S.; PITTS, W.H. What the frog's eye tells the frog's brain. Proceedings of the IRE, v.4711, p.1940-1951, 1959.

LIPTON, S.A.; TAUCK, D.L. Voltage-dependent conductances of solitary ganglion cells dissociated from the rat retina. Journal of Physiology (London), v.385, p.361-391, 1987.

LIU, X.D.; KOURENNYI, D.E.; Effects of tetraethylammonium on Kx channels and simulated light response in rod photoreceptors. Annals of Biomedical Engineering, v.32, p.1428-1442, 2004.

MAO ,BQ.; MACLEISH, P.R.; VICTOR, J.D.2003 Role of Hyperpolarization-Activated Currents for the Intrinsic Dynamics of Isolated Retinal Neurons. Biophysical Journal, v.84, p.27562767, .

MARICQ, A.V.; KORENBROT, J.I. Potassium currents in the inner segment of single retinal cone photoreceptors. Journal of Neurophysiology, v.64, p.1929-1940, 1990.

MILLER, R.F.; STAFF, N.P.; VELT, T.J. Form and Function of ON-OFF Amacrine Cells in the Amphibian Retina. Journal of Nuerophysiology, v.955, p.3171-3190, 2006. 
MILLS, S.L.; MASSEY, S.C. A series of biotinylated tracers distinguishes three types of gap junction in retina. Journal of Neuroscience, v.2022, p.8629-8636, 2000.

MUKAI S.; MISHIMA, H.K.; SHOGE, K.; SHINYA, M.; ISHIHARA, K.; SASA M. Existence of ionotropic glutamate receptor subtypes in cultured rat retinal ganglion cells obtained by the magnetic cell sorter method and inhibitory effects of 20-hydroxyecdysone, a neurosteroid, on the glutamate response. Japanese Journal of Pharmacology, v.89, p.44-52, 2002.

NIZAMI, L. Estimating auditory neuronal dynamic range using a fitted function. Hearing Research, v.1671-2, p.13-27, 2002.

OGURA, T.; SATOH, T.O.; USUI, S.; YAMADA, M. A simulation analysis on mechanisms of damped oscillation in retinal rod photoreceptor cells. Vision Research, v.43, p.2019-2028, 2003.

PUBLIO, R.; OLIVEIRA, R.F.; ROQUE, A.C. A realistic model of rod photoreceptor for use in a retina network model. Neurocomputing, v.69, p.1020-1024, 2006.

PUGH, E.N. ; LAMB, T.D. Phototransduction in vertebrate rods and cones: molecular mechanisms of amplification, recovery and light adaptation. In: Elsevier Science. Handbook of biological physics. Molecular mechanisms of visual transduction., STAVENGA, D.G.; DE GRIP, W.J.; PUGH, E.N. , 2000. cap. , p.183-255.

RALL, W. Distinguishing theoretical synaptic potentials computed for different soma-dendritic distribution of synaptic inputs. Journal of Neurophysiology, v.305, p.1138-1168, 1967.

RALL, W.; BURKE, R.E.; HOLMES, W.; JACK, J.B.; REDMAN, S.J.; SEGEV, I. Matching dendritic neuron models to experimental data. Physilogical Reviews, v.724, p.159-189, 1992.

RAVIOLA, E. ; GILULA, N.B. Gap Junctions between Photoreceptor Cells in the Vertebrate Retina. Proceedings of the National Academy of Sciences, v.706, p.1677-1681, 1973.

RISPOLI G. Calcium regulation of phototransduction in vertebrate rod outer segments. Journal of Photochemistry and Photobiology B, v.441, p.1-20, 1998.

RODIECK, R. W. The primate retina. Comparative Primate Biology, v.41, p.203-278, 1988.

RODIECK, R.W. The First Steps in Seeing. ., Sinauer Associates, 1998.

SAEZ, J.C.; BERTHOUD, V.M.; BRANES, M.C.; MARTINEZ, A.D.; BEYER, E.C. Plasma membrane channels formed by connexins: their regulation and functions. Physiological Reviews, v.834, p.1359-1400, 2003.

SCHNEEWEIS, D.M.; SCHNAPF, J.L. The Photovoltage of Macaque Cone Photoreceptors: Adaptation,Noise, and Kinetics. Journal of Neuroscience, v.19, p.1203-1216, 1999.

SEGEV, I. Dendritic processing. In: ARBIB, M. A. (Ed.). The handbook o brain theory and neural networks. Cambridge, MITPress, 1995. cap. 25, p.282-289. 
SHEASBY, B.W.; FOHLMEISTER, J.F. Impulse encoding across the dendritic morphologies of retinal ganglion cells. Journal of Neurophysiology, v.814, p.1685-1698, 1999.

SHERPHERD, G .M.AND KOCH, C. Introduction to Synaptic Circuits. In: SHEPHERD, G. M., (Ed.). The synaptic organization of the brain. New York, OXFORD UNIVERSITY PRESS, 2004. cap. 1, p.205-253.

SIKORA, M.A.; GOTTESMAN, J.; MILLER, R.F. A computational model of the ribbon synapse. Journal of Neuroscience Methods, v.145, p.47-61, 2005.

SMITH, R.; BRACHMAN, M.L. Operating range and maximum response of single auditory nerve fibers. Brain Research, v.184, p.499-505, 1980.

SMITH, R.G.; VARDI, N. Simulation of the AII amacrine cell of mammalian retina: Functional consequences of electrical coupling and regenerative membrane properties. Visual Neuroscience, v.12, p.851-860, 1995.

STEIN, J.J.; JOHNSON, S.A.; BERSON, D.M. Distribution and coverage of beta cells in the cat retina. Journal of Comparative Neurology, v.3724, p. 597-617, 1996.

STERLING, P. Retina. In: SHEPHERD, G. M., (Ed.). The synaptic organization of the brain. New York, OXFORD UNIVERSITY PRESS, 1998. cap. 6, p.205-253.

STERLING, P.; FREED, M.A.; SMITH R.G. Architecture of rod and cone circuits to the on-beta ganglion cell. Journal of Neuroscience, v.8, p.623-642, 1988.

TESSIER-LAVIGNE, M.; ATTWELL, D. The effect of photoreceptor coupling and synapse nonlinearity on signal/noise ratio in early visual processing. Proceedings of the Royal SocieQ (London) B, v.234, p.171-197, 1988.

TSUKAMOTO, Y.; MORIGIWA, K.; UEDA, M.; STERLING, P. Microcircuits for night vision in mouse retina. Journal of Neuroscience, v.2121, p.8616-8623, 2001.

USUI, S; ISHIHARA, A.; KAMIYAMA, Y.; ISHII, H. Ionic Current Model of Bipolar Cells in the Lower Vertebrate Retina. Vision Research, v.36, p.4069-4076, 1996.

VARDI, N.; SMITH, R.G. The AII Amacrine Network: Coupling can Increase Correlated Activity. Vision Research, v.36, p.3743-3757, 1996.

VOLGYI, B.; DEANS, M.R.; PAUL D.L.; BLOOMFIELD L.A. Convergence and segregation of the multiple rod pathways in mammalian retina. Journal of Neuroscience, v.24, p.11182-11192, 2004.

WEILER, R.; POTTEK, M.; HE, S.; VANEY, D.I. Modulation of coupling between retinal horizontal cells by retionic acid and endogenous dopamine. Brain Research, v.321, p.121-129, 2000. 
XIN, D.; BLOOMFIELD, S.A. Tracer coupling pattern of amacrine and ganglion cells in the rabbit retina. The Journal of Comparative Neurology, v.383, p.512-528, 1997.

ZHANG, J.; WU, S.M. Physiological properties of rod photoreceptor electrical coupling in the tiger salamander retina. Journal of Physiology, v.564, p.849-862, . 